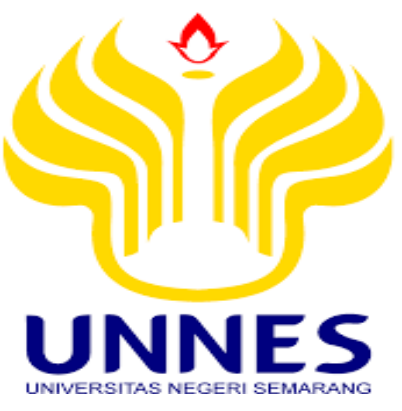

\title{
EKSISTENSI TARI RONGGENG BUGIS DI SANGGAR PRINGGADHING PLUMBON CIREBON
}

\section{SKRIPSI}

Untuk memperoleh gelar Sarjana Pendidikan Prodi Pendidikan Seni Tari

Oleh

$\begin{array}{ll}\text { Nama } & : \text { RosdianaWati } \\ \text { NIM } & : 2501413027 \\ \text { Program Studi } & : \text { Pendidikan Seni Tari } \\ \text { Jurusan } & : \text { Seni Drama Tari dan Musik }\end{array}$

FAKULTAS BAHASA DAN SENI UNIVERSITAS NEGERI SEMARANG 


\section{PERSETUJUAN PEMBINIBING}

Skripsi dengan judul Eksistensi Tari Ronggeng Bugis di Sanggar Pringgadhing Plumbon Cirebon ini sudah disetujui oleh dosen pembimbing untuk diajukan ke Sidang Panitia Ujian Skripsi Jurusan Pendidikan Seni Drama, Tari dan Musik Fakultas Bahasa dan Seni Universitas Negeri Semarang.

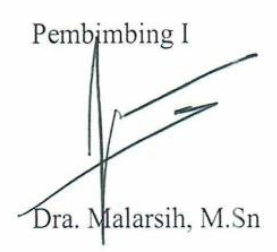

NIP. 196106171988032001
Semarang, 22 September 2017

Pembimbing II

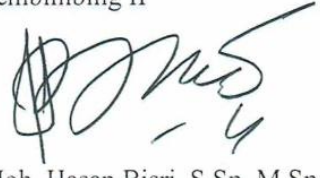

Moh. Hasan Bisri, S.Sn, M.Sn

NIP. 196601091998021001 


\section{PENGESAHAN KELULUSAN}

Skripsi ini telah dipertahankan di depan Sidang Panitia Ujian Skripsi Jurusan Pendidikan Seni Drama, Tari dan Musik Fakultas Bahasa dan Seni Universitns Negeri Semarang pada:

$$
\begin{array}{ll}
\text { hari } & : \text { Kamis } \\
\text { tanggal } & : 28 \text { September } 2017 \\
& \text { Panitia Ljian Skripsi }
\end{array}
$$

Prof. Dr. Agus Nuryatin, M.Hum

NIP. 196008031989011001

Ketua

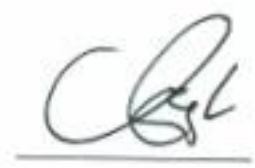

Abdul Rachman. S.Pd., M.Pd

NIP, 198001202006041002

Sekretaris

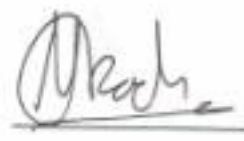

Dra. V. Eny Iryanti, M.Pd

NIP. 195802101986012001

Penguji 1

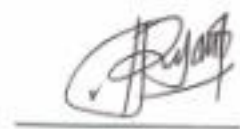

Moh. Hasan Bisri, S.Sn., M.Sn

NIP, 196601091998021001

Penguji II/Penbimbing 2

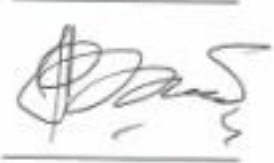

Dra. Malarsit, M.Sn

NIP. 196106171983032001

Penguji IIIPembimbing I
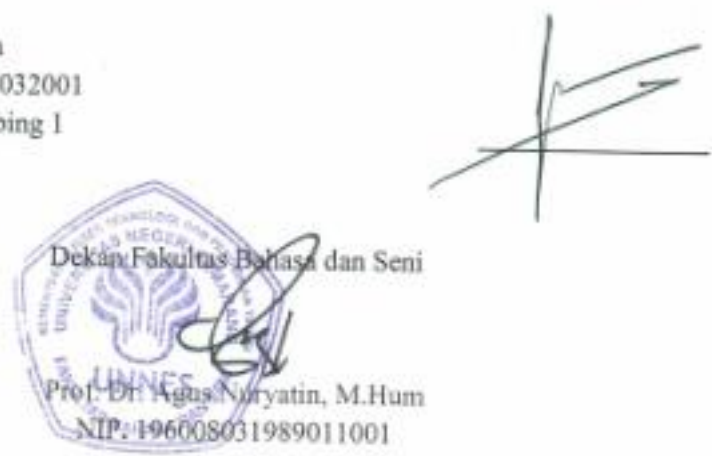

iii 


\section{PERNYATAAN}

Saya menyatakan bahwa yang tertulis di dalam skripsi ini benar-benar hasil karya saya sendiri, bukan jiplakan dari karya orang lain, baik sebagian atau seluruhnya. Pendapat atau temuan orang lain yang terdapat dalam skripsi ini dikutip atau dirujuk berdasarkan kode etik ilmiah.

Semarang, September 2017

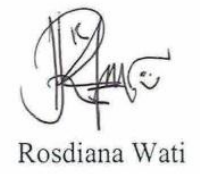

2501413027 


\section{MOTTO DAN PERSEMBAHAN}

\section{MOTTO:}

"Penolong Terbaik Setelah Allah adalah Kebaikanmu"

\section{PERSEMBAHAN:}

Sripsi ini kupersembahakan:

1. Untuk mamah atas segala doa dan perjuangannya sampai saat ini

2. Untuk babeh yang senantiasa memberi doanya.

3. Untuk kakak dan adikku ( Ceu Mela, Ceu Indah, dan adi) yang aku sayangi.

4. Untuk umi dan bibi yang aku sayangi

5. Untuk Sanggar Pringgadhing yang telah dengan senang hati menjadi tempat penelitian saya.

6. Untuk pengembang ilmu semoga penlitian ini menjadi acuan untuk penelitianpenelitian selanjutnya tentang Tari Ronggeng Bugis dengan kajian yang berbeda dan lebih mendalam. 


\section{SARI}

Wati, Rosdiana. 2017. Eksistensi Tari Ronggeng Bugis di Sanggar Pringgadhing Plumbon Cirebon. Skripsi, Jurusan Pendidikan Seni Drama, Tari dan Musik, Fakultas Bahasa dan Seni, Universitas Negeri Semarang. Pembimbing I: Dra. Malarsih, M.Sn. Pembimbing II: Moh. Hasan Bisri, S.Sn., M.Sn.

Kata Kunci: Eksistensi, Tari Ronggeng Bugis,

Tari Ronggeng Bugis merupakan tari tradisi yang ada di Kabupaten Cirebon yang pertama kali diangkat menjadi sebuah tari pertunjukan oleh bapak Handoyo (alm). Tari Ronggeng Bugis temasuk tarian jenaka, yang lucu dan menghibur. Berbeda dengan tari Ronggeng lain, tari Ronggeng Bugis ditarikan oleh laki-laki dan bukan ditarikan oleh perempuan. Keberadaan tari Ronggeng Bugis sendiri sudah diakui oleh masyarakat Cirebon kota dan Cirebon barat. Sedangkan di Cirebon timur nama tari Ronggeng Bugis cukup asing dan tidak banyak orang mengetahui salah satu tari tradisi Cirebon tersebut, hal ini dikarenakan kurangnya publikasi tentang tari Ronggeng Bugis di daerah Cirebon timur.

Berdasarkan paparan tersebut, masalah penelitian ini adalah bagaimana eksistensi tari Ronggeng Bugis di Sanggar Pringgadhing Plumon Cirebon. Upaya apa saja yang dilakukan untuk menunjukan eksistensi tari Ronggeng Bugis yang ada di Sanggar Pringgadhing. Tujuan penelitian ini adalah untuk dapat mengetahui, dan mendeskripsikan bagaimana eksistensi tari Ronggeng Bugis di Sanggar Pringgadhing Plumbon Cirebon.

Penelitian ini menggunakan metode penelitian deskriptif kualitatif. Penelitian kualitatif ini menggunakan Teknik pengumpulan data melalui observasi mengenai tempat penelitian dan bentuk pertunjukan tari Ronggeng Bugis, kemudian wawancara dengan beberapa sumber yaitu ketua sanggar, dinas pariwisata dan budaya Kabupaten Cirebon, kepala sekolah, penari, pelatih, dan penonton. dan dokumentasi penelitian maupun dokumentasi peneliti. Teknik analisis data pada penelitian ini dengan mereduksi data yaitu memilih data-data yang penting atau data primer yang kemudian dianalisis sehingga dapat ditarik kesimpulannya.

Hasil penelitian ini menunjukan bahwa tari Ronggeng Bugis di Sanggar Pringgadhing masih eksis dan dikenal oleh masyarakat Cirebon. dengan pembuktian adanya pementasan tari Ronggeng Bugis sampai tahun 2017 ini. Serta adanya kerjasama dengan instansi pemerintahan seperti dinas kebudayaan dan sekolah. Dengan tujuan melestarikan kebudayaan Cirebon dan sebagai sarana pendidikan. Berdasarkan hasil dan pembahasan tersebut maka dikatakan bahwa tari Ronggeng Bugis di Sanggar Pringgadhing Plumbon Cirebon masih eksis.

Semoga semua pihak terutama Sanggar Pringgadhing dan Dinas Kebudayaan Daerah setempat dapat lebih menjaga kelestarian dan eksistensi tari Ronggeng Bugis dengan mendokumentasikan secara baik dan membukukan sejarahnya serta mempublikasikan lewat media sosial dan pementasan yang lebih sering termasuk di Cirebon Timur. 


\section{PRAKATA}

Puji syukur peneliti sampaikan atas kehadirat Allah SWT yang telah memberi begitu banyak nikmat berupa iman, islam dan kesehatan, serta taufik dan karunia-Nya. Sehingga penulis dapat menyelesaikan skripsi yang berjudul Eksistensi Tari Ronggeng Bugis Di Sanggar Pringgadhing Plumbon Cirebon. skripsi ini disusun untuk memenuhi persyaratan guna memperoleh gelar Sarjana Pendidikan.

Peneliti menyadari sepenuhnyaa bahwa selesainya skripsi dan keberhasilan dalam penulisan skripsi ini tidak lepas dari bimbingan, arahan, dan bantuan dari beberapa pihak. Oleh karena itu peneliti mengucapkan terima kasih yang tulus kepada:

1. Prof. Dr. Fathur Rokhman, M.Hum., selaku Rektor Universitas Negeri Semarang, yang telah memberikan kesempatan pada saya untuk belajar di Universitas Negeri Semarang

2. Prof. Dr. Agus Nuryatin, M.Hum., selaku Dekan Fakultas Bahasa dan Seni Universitas Negeri Semarang, yang telah memberikan ijin untuk penelitian.

3. Prof. Dr. M. Jazuli, M.Hum., selaku Dosen wali yang telah memberi motivasinya untuk menyelesaikan skripsi.

4. Dr. Udi Utomo, M.Si., selaku Ketua Jurusan Pendidikan Seni Drama Tari dan Musik, yang telah memberikan motivasinya untuk menyelesaikan skripsi.

5. Dra. Malarsih, M.Sn., selaku Dosen Pembimbing I yang telah sabar membimbing, memberi arahan, masukan dan motivasi dalam menyelesaikan skripsi ini. 
6. Moh. Hasan Bisri, S.Sn, M.Sn., selaku Dosen Pembimbing II yang telah sabar membimbing, memberi arahan, masukan dan motivasi dalam menyelesaikan skripsi ini.

7. Seluruh Dosen Pendidikan Sendratasik yang telah menyampaikan ilmunya kepada peneliti

8. Keluarga besar Sanggar Pringgadhing yang telah berkenan dan bersedia memberikan izin penelitian kepada peneliti dalam pengumpulan data untuk penyusunan skripsi ini.

9. Teman-teman sendratasik angkatan 2013 yang telah menjadi teman belajar peneliti selama menuntut ilmu di Sendratasik Unnes dan memberikan motivasinya.

10. Semua pihak yang tidak dapat peneliti sebut satu-persatu yang telah membantu dalam penyusunan skripsi ini.

Peneliti berharap semoga Allah SWT membalas kebaikan yang telah semua pihak berikan kepada peneliti, karena peneliti sadar bahwa kekurangan hanya milik peneliti dan kesempurnaan hanya milik Allah SWT. Oleh karena itu segala kritik dan saran yang bersifat membangun, peneliti terima dengan senang hati. Peneliti juga berharap semoga skripsi ini bermanfaat bagi peneliti, pembaca dan dunia pendidikan.

Semarang, September 2017

Peneliti 


\section{DAFTAR ISI}

Halaman

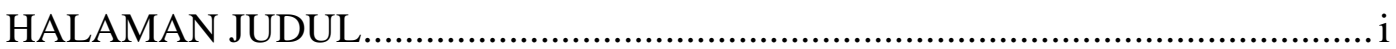

HALAMAN PERSETUJUAN PEMBIMBING …............................................... ii

HALAMAN PENGESAHAN KELULUSAN .......................................................ii

HALAMAN PERNYATAAN ....................................................................... iv

HALAMAN MOTTO PERSEMBAHAN ……...............................................

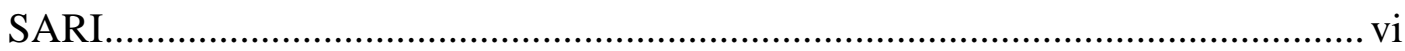

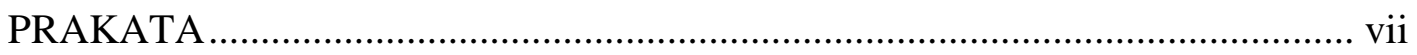

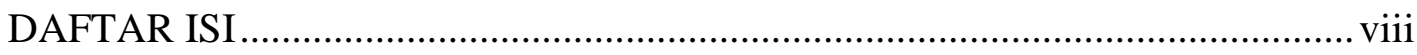

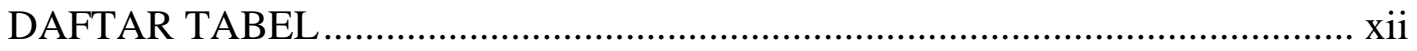

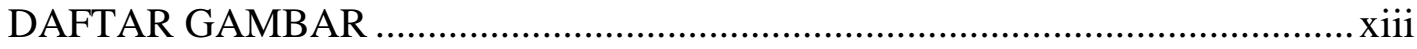

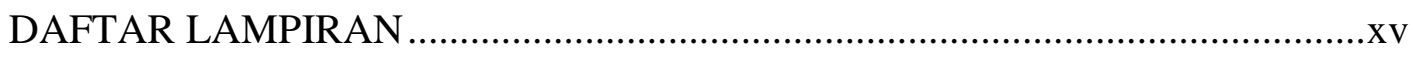

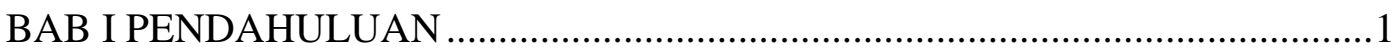

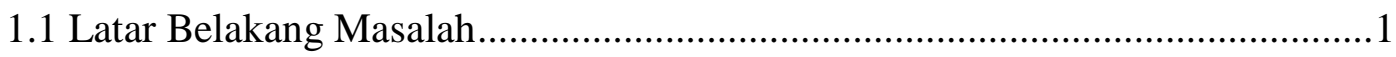

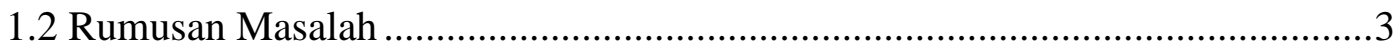

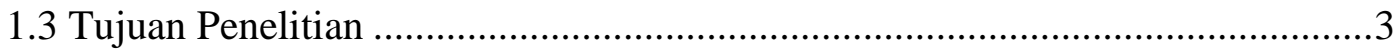

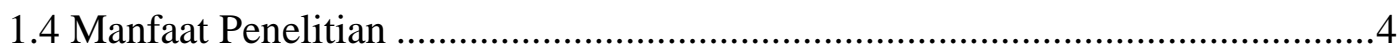

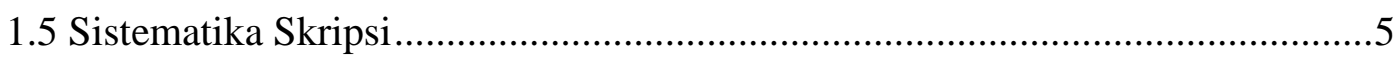

BAB II TINJAUAN PUSTAKA DAN LANDASAN TEORITIS .........................

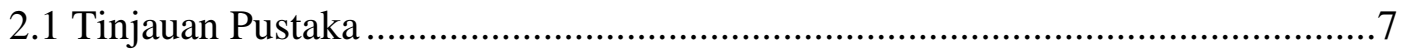

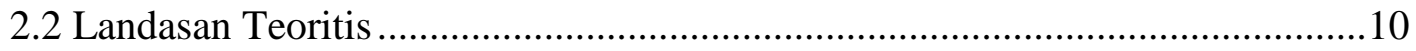

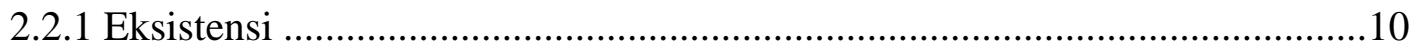




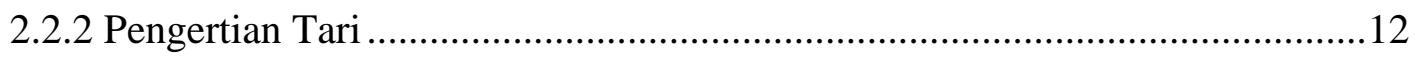

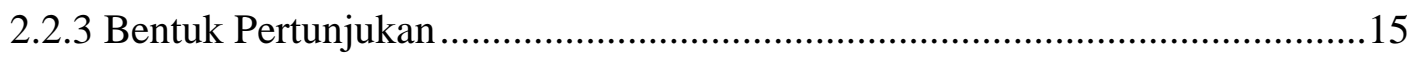

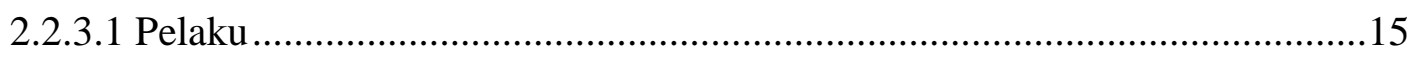

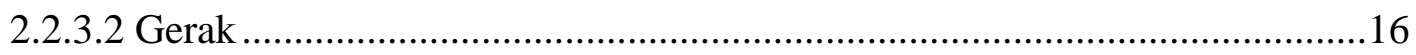

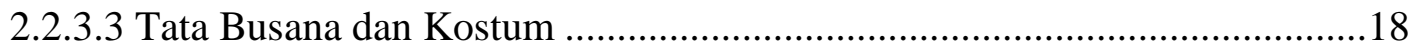

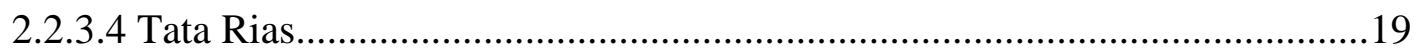

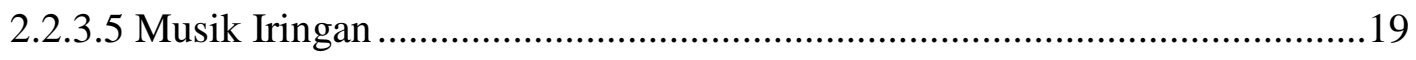

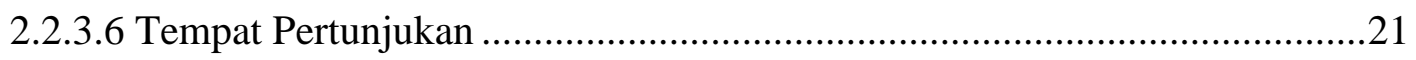

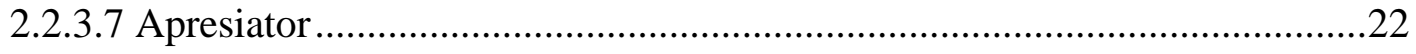

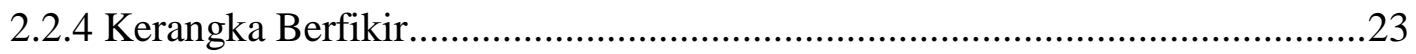

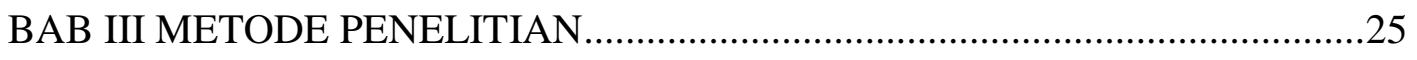

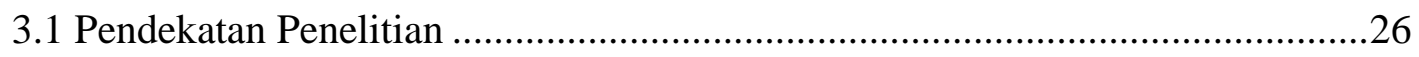

3.2 Lokasi dan Sasaran Penelitian...................................................................2 27

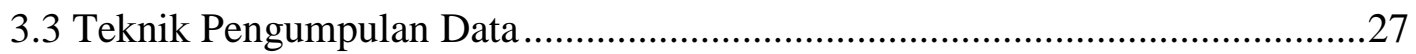

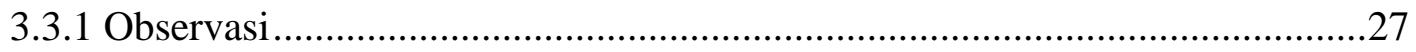

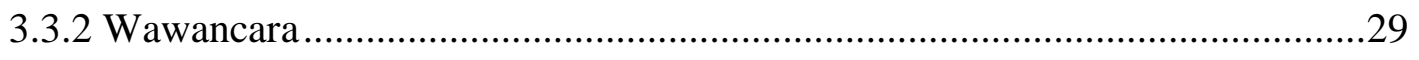

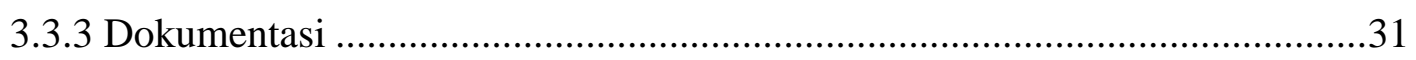

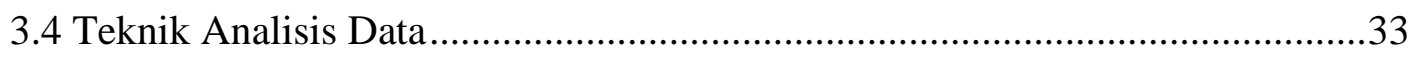

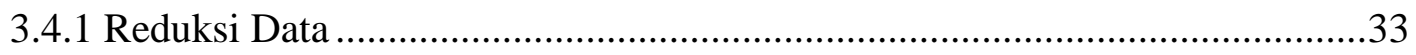

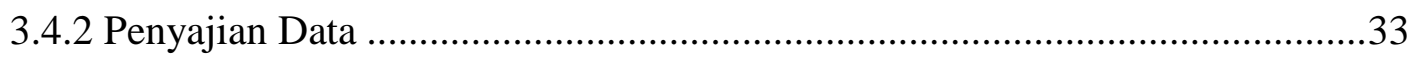

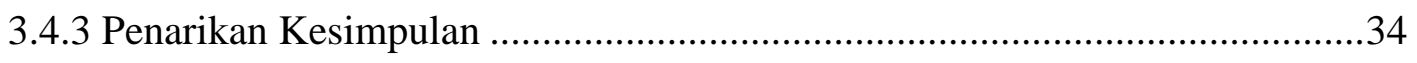

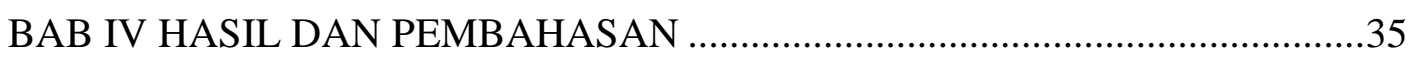

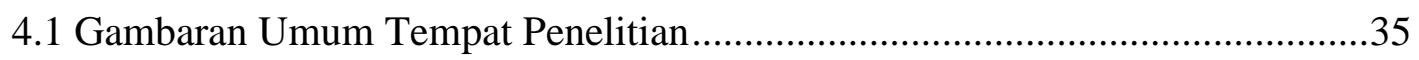




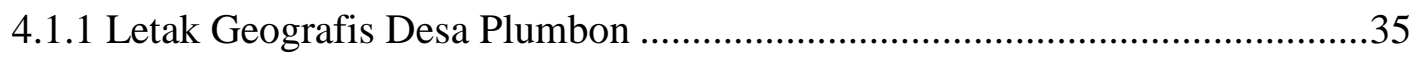

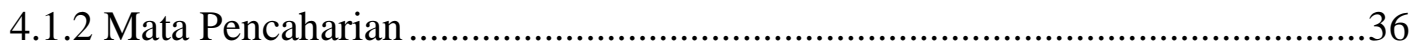

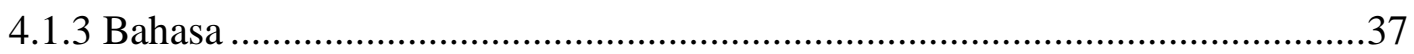

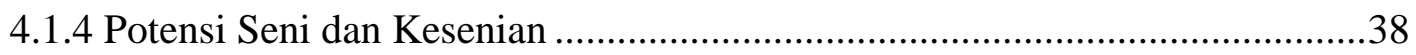

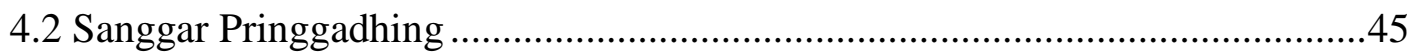

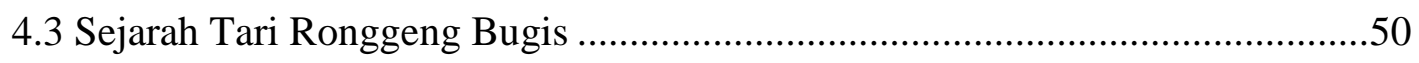

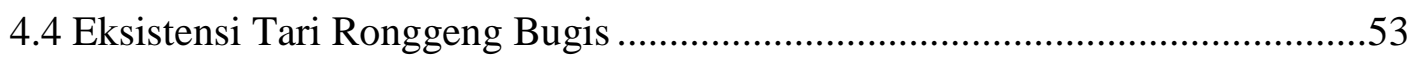

4.5 Upaya-Upaya Mempertahankan Tari Ronggeng Bugis ..................................57

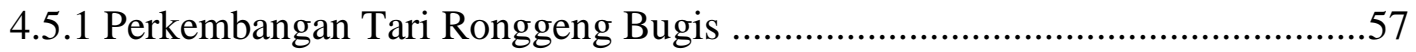

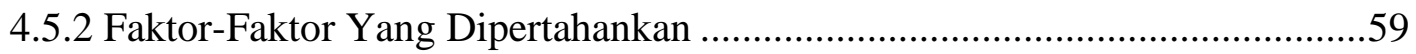

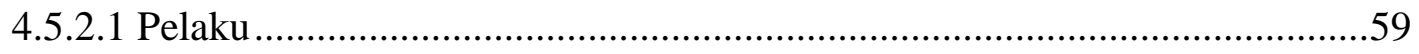

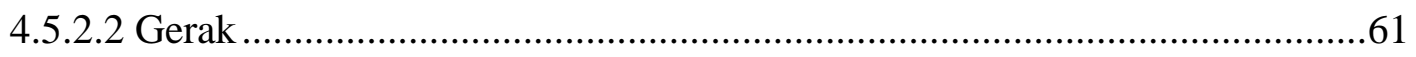

4.5.2.3 Tata Busana dan Kostum Tari Ronggeng Bugis ......................................68

4.5.2.4 Tata Rias Make Up Tari Ronggeng Bugis ..................................................77

4.5.2.5 Musik Pengiring Tari Ronggeng Bugis ................................................... 78

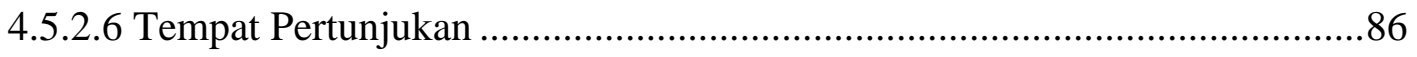

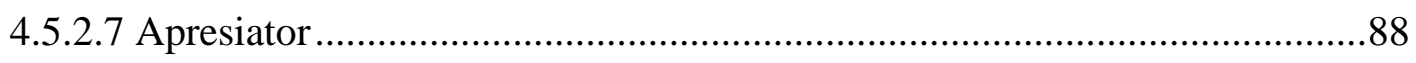

4.5.3 Penyebarluasan Tari Ronggeng Bugis .................................................. 90

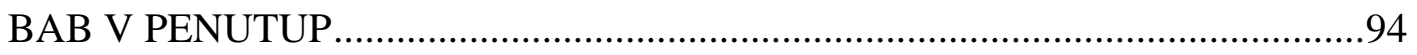

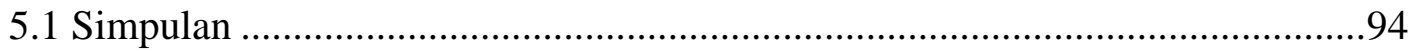

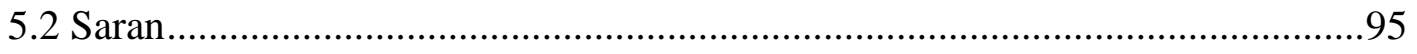

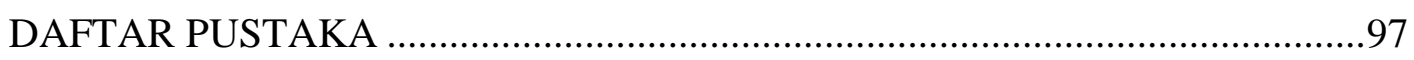

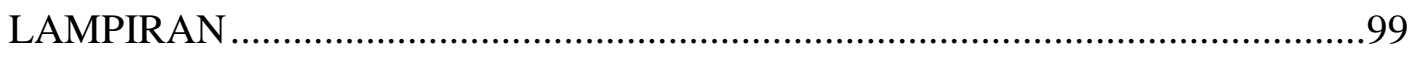




\section{DAFTAR TABEL}

Halaman

Tabel 4.1.2 Mata Pencaharian Masyarakat Desa Plumbon..................................36

Tabel 4.1.4.1 Kesenian musik dan nama grup sanggar di Kab. Cirebon .................39

Tabel 4.1.4.2 Kesenian wayang, sandiwara dan nama grup di Kab. Cirebon..........41

Tabel 4.1.4.3 Kesenian Tari dan nama grup sanggar di Kab. Cirebon ...................43

Tabel 4.2 Nama-nama siswa Sanggar Pringgadhing....................................47

Tabel 4.5.2.2 Deskripsi ragam gerak tari Ronggeng Bugis .................................62 


\section{DAFTAR GAMBAR}

Halaman

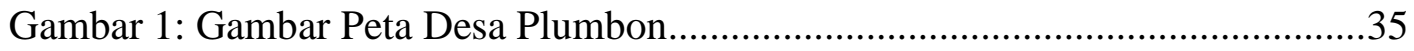

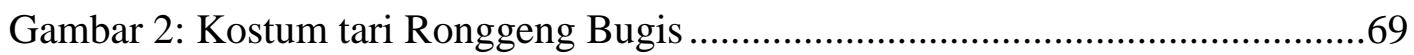

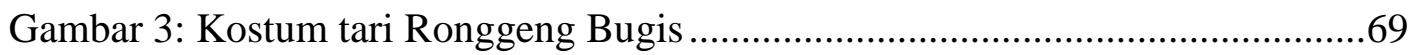

Gambar 4: Kebaya motif berwarna terang .................................................... 70

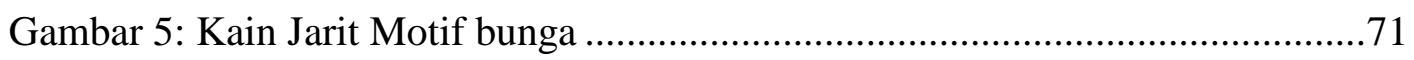

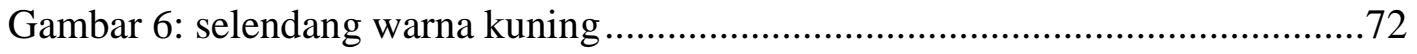

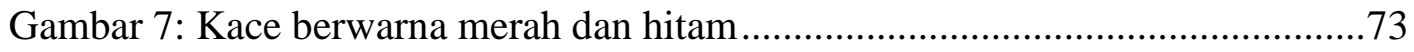

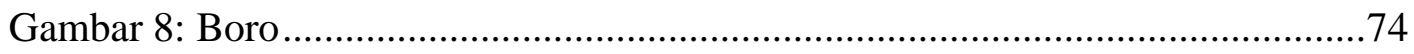

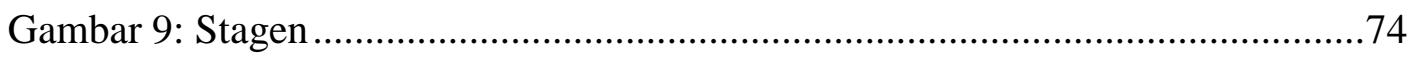

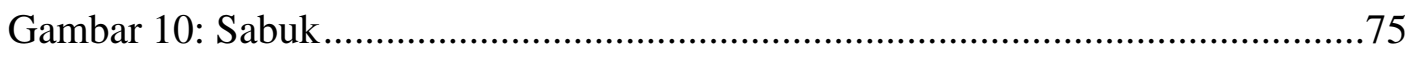

Gambar 11: Bando Kembang Goyang ...........................................................76

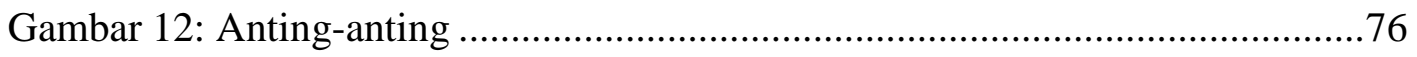

Gambar 13: Rias Karakter badut untuk tari Ronggeng Bugis................................78

Gambar 14: Alat musik tradisional Cirebon Saron ............................................ 81

Gambar 15: Alat musik tradisional Cirebon Bonang ......................................... 82

Gambar 16: Alat musik tradisional Cirebon Kemyang........................................82

Gambar 17: Alat musik tradisional Cirebon Kebluk.............................................83

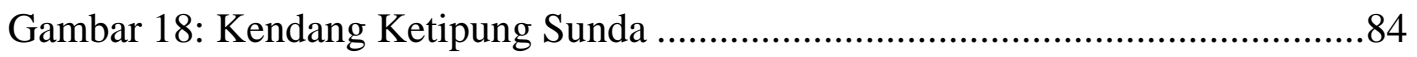

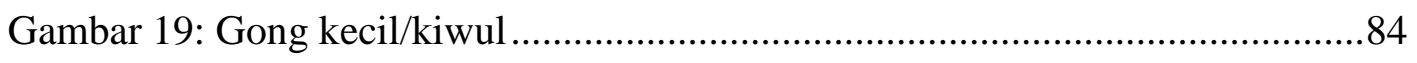

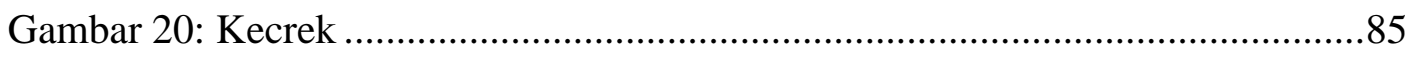

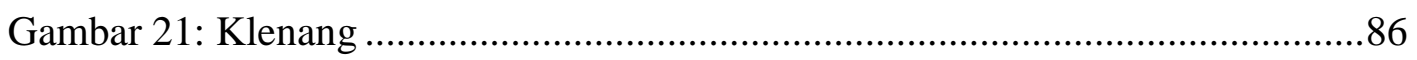


Gambar 22: Panggung Pertunjukan Tari Ronggeng .87

Gambar 23: Tari Ronggeng Bugis di Pangung Terbuka......................................87

Gambar 24: Helaran Car Free Day di Siliwangi Cirebon. .88 


\section{DAFTAR LAMPIRAN}

Halaman

Lampiran 1: Glosarium .99

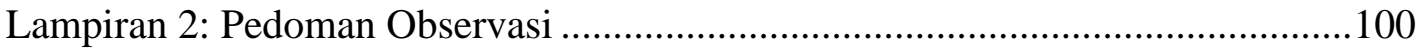

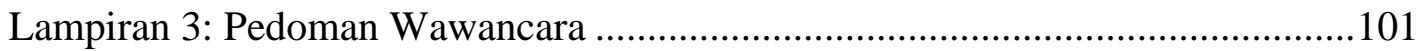

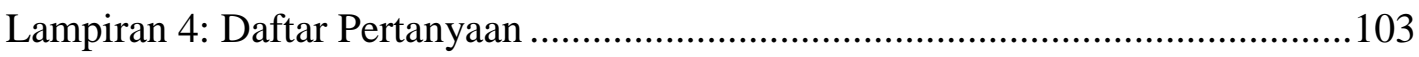

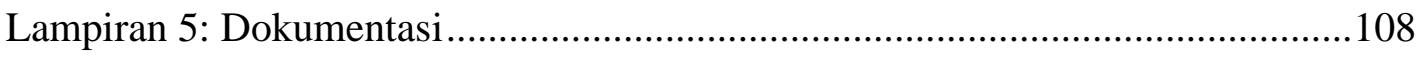




\section{BAB I}

\section{PENDAHULUAN}

\subsection{Latar Belakang}

Cirebon adalah salah satu kota di Provinsi Jawa Barat. Cirebon merupakan kota perbatasan antara provinsi Jawa Barat dan Jawa Tengah. Kota Cirebon memiliki penduduk yang rata-rata bermata pencaharian nelayan dan petani. Kesenian yang ada di Kota Cirebon diantaranya adalah seni musik dan seni tari. dibidang seni tari diantaranya ada tari topeng, sintren, dan Tari Ronggeng Bugis.

Eksistensi atau keberadaan Tari Ronggeng Bugis dimasyarakat Cirebon sudah mengalami kemajuan. Dengan banyaknya masyarakat yang mengenal dan mengetahui tari yang biasa disebut telik sandi itu membuktikan bahwa tari Ronggeng Bugis eksis, keberadaannya diakui oleh masyarakat dan penonton atau penikmat seni. Tari Ronggeng Bugis cukup terkenal di daerah Cirebon kota, sedangkan di daerah Cirebon timur, Tari Ronggeng Bugis tidak cukup terkenal karena kurangnya pementasan tari di daerah Cirebon Timur terutama Tari Ronggeng Bugis. Meskipun setiap keberadaan suatu karya khususnya karya seni tidak semua masyarakat dapat menerima eksistensinya, namun jika ada sebagian dari mereka yang mengapresiasi karya seni itu dengan baik maka menjadi hal yang membanggakan bagi para seniman yang berkarya maupun yang telah ikut berpartisipasi didalamnya.

Tari Ronggeng Bugis berbeda dengan tari Ronggeng lain yang biasanya penarinya itu wanita dan identik dengan tari pergaulan namun keunikan yang terdapat pada tari Ronggeng Bugis di Sanggar Pringgadhing yaitu ditarikan oleh 
laki-laki dan tariannya juga jenaka, tarian yang lucu. Kelucuan yang terdapat dalam gerakan-gerakan yang dilakukan oleh para penari mengundang gelak tawa penonton dan menjadi salah satu tampilan seni pertunjukan yang diminati dan ditunggu-tunggu oleh masyarakat Cirebon setiap kali ada pentas seni budaya pada hari-hari besar Kabupaten Kota Cirebon, misalnya pada hari jadi Cirebon.

Tari Ronggeng Bugis bersifat menghibur, tarian jenaka yang biasa dikenal oleh masyarakat Jawa dengan nama dagelan. Tarian ini merupakan salah satu tari tradisi yang ada di Cirebon. Tari Ronggeng yang identik dengan penari wanita yang cantik dan tentu menjadi idola bagi para laki-laki pada jaman dahulu bahkan sampai saat ini. Uniknya Tari Ronggeng Bugis yang ada di Cirebon ditarikan oleh para prajurit laki-laki pada masa kerajaan Sunan Gunung Jati. Tari Ronggeng Bugis pada masa pemerintahan Sunan Gunung Jati dijadikan sebagai alat komunikasi kerajaan dengan musuh untuk mendapatkan sebuah informasi yang bisa menguntungkan bagi pemerintahan Sunan Gunung Jati. Sampai saat ini Tari Ronggeng Bugis biasa ditarikan oleh laki-laki bukan perempuan. Karena keunikannya itu Tari Ronggeng Bugis menjadi salah satu kesenian yang disukai oleh masyarakat Cirebon. Mulai dari kalangan orang dewasa hingga anak-anak menyukai tarian yang menghibur seperti tari Ronggeng Bugis ini.

Diakuinya Tari Ronggeng Bugis di kota Cirebon tak lain karena adanya kiprah para pelaku seni dan sanggar yang ikut serta dalam melestarikan dan mengembangkannya sampai saat ini. Sanggar sangat perperan penting dalam menentukan kemajuan atau kemunduran suatu karya seni. 
Sanggar Pringgadhing adalah salah satu sanggar yang ada di Cirebon, lebih tepatnya berada di Desa Plumbon, Kecamatan Plumbon, Kabupaten Cirebon Jawa Barat. Sanggar ini didirikan oleh bapak Handoyo (alm) pada tanggal 2 september 1974. Tari Ronggeng Bugis diangkat oleh alm bapak Handoyo pada tahun 90'an dan sekarang dilanjutkan oleh istri dan anaknya. Pada saat ini tahun 2017 Tari Ronggeng Bugis sudah mengalami perkembangan, baik tarinya dan bentuk pertunjukannya. Bentuk asli dari Tari Ronggeng Bugis pada awalnya hanya memiliki tiga ragam gerakan dan kemudian dikembangkan oleh bapak Handoyo menjadi 17 gerakan. Awalnya dipentaskan di jalan-jalan atau lapangan terbuka dan sekarang sudah dipentaskan di atas panggung pertunjukan. Selain menjadi salah satu materi yang diajarkan di sanggar, Tari Ronggeng Bugis sudah menjadi salah satu seni tari yang dijadikan bahan ajar untuk ujian praktik di sekolah.

Berdasarkan latar belakang yang telah dipaparkan maka mengapa memiilih Tari Ronggeng Bugis adalah untuk mengetahui eksistensi atau keberadaan, perkembangan dan bentuk pertunjukan Tari Ronggeng Bugis dimasyarakat Cirebon.

\subsection{Rumusan Masalah}

Berasarkan latar belakang yang telah dijelaskan maka permasalahan dalam penelitian ini adalah:

1.2.1 Bagaimana eksistensi Tari Ronggeng Bugis di Sanggar Pringgadhing Plumbon Cirebon?

\subsection{Tujuan Penelitian}


Berdasarkan rumusan masalah yang telah dikemukakan, maka tujuan penelitian adalah:

1.3.1 Mengetahui, dan mendeskripsikan bagaimana Eksistensi Tari Ronggeng Bugis di Sanggar Pringgadhing Plumbon Cirebon.

\subsection{Manfaat Penelitian}

\subsubsection{Manfaat Teoritis}

\subsubsection{Manfaat bagi peneliti}

Manfaat bagi peneliti adalah mengetahui bagaimana keberadaan atau eksistensi tari Ronggeng Bugis di Sanggar Pringgadhing Plumbon Cirebon. Mengetahui upaya apa saja yang dilakukan untuk mempertahankan Eksistensi Tari Ronggeng Bugis di Sanggar Pringgadhing Plumbon Cirebon.

\subsubsection{Manfaat bagi pembaca}

Bagi pembaca hasil penelitian tari Ronggeng Bugis di Sanggar Pringgadhing Plumbon Cirebon semoga dapat dijadikan bahan acuan atau rujukan untuk penelitian-penelitian selanjutnya dengan mengambil objek yang sama namun dengan topik yang berbeda.

\subsubsection{Manfaat Praktis}

Secara praktis penelitian ini dapat bermanfaat untuk beberapa pihak dintaranya :

\subsubsection{Manfaat Bagi Peneliti}

Penelitian tari Ronggeng Bugis di Sanggar Pringgadhing Plumbon Cirebon dapat dijadikan acuan pengembangan teori terhadap objek penelitian serta sebagai cara untuk ikut melestarikan tari Ronggeng Bugis dengan melihat eksistensinya di 
Cirebon. Serta mengenal lebih jauh tentang kesenian-kesenian yang ada di Cirebon khususnya tentang tari Ronggeng Bugis.

\subsubsection{Manfaat Bagi Sanggar}

Bagi Sanggar Pringgading agar bisa menjadi contoh sanggar-sanggar lain dalam mengembangkan tari Ronggeng Bugis. Lebih memotivasi para pembelajar seni tari Ronggeng Bugis agar bisa ikut serta melestarikan dan dapat menambah apresiator seni dalam pengembangan bentuk pertunjukan tari Ronggeng Bugis. Dapat dijadikan acuan supaya bisa menjadi contoh sanggar-sanggar lain yang memiliki tarian yang sama, lebih semangat lagi dan tetap kompak dalam ikut serta melestarikan budaya Indonesia khususnya budaya kesenian daerah Cirebon.

\subsubsection{Manfaat Bagi Pemerintah Daerah}

Bagi pemerintah daerah setempat diharapkan dapat lebih memotivasi dan mendukung serta mengenalkan tari Ronggeng Bugis ke luar kota Cirebon. Dapat memepertahankan fungsi utama tari Ronggeng Bugis sebagai tari tradisi yaitu menjadi salah satu aset kesenian daerah Cirebon yang mampu menjadi kebanggaan dan bisa dijadikan identitas daerah.

\subsection{Sistematika Skripsi}

Untuk mendapatkan hasil yang maksimal dan data-data yang relevan maka harus dipahami terlebih dahulu sistematikanya seperti apa, demikian sistematika penulisan skripsi sebagai berikut:

\section{Bab I Pendahuluan}

\section{Latar Belakang}


Latar belakang berisi tentang eksistensi tari Ronggeng Bugis Cirebon secara umum, pokok bahasan yang akan dikaji, keunikan objek yang akan dikaji.

\section{Rumusan Masalah}

Rumusan masalah menjelaskan tentang batasan masalah apa saja yang akan dikaji.

\section{Tujuan Penelitian}

Tujuan dilakukannya penelitian mengenai topik dan objek yang akan dikaji.

\section{Manfaat Penelitian}

Sub-bab ini menjelaskan tentang manfaat teoritis dan manfaat praktis yang dilakukan peneliti tentang penelitian yang akan dilakukan.

\section{Sistematika Penulisan Skripsi}

Sistematika penelitian menjabarkan susunan penulisan dan pokok bahasan dari masing-masing bab dan sub-bab.

\section{Bab II Landasan Teori}

Dasar teori berisi tentang pembahasan penelitian yang relevan dengan penelitian yang telah dilakukan oleh orang lain serta membahas teori-teori penunjang mengenai topik dan objek yang akan dikaji oleh peneliti.

\section{Bab III Metode Penelitian}

Dalam bab ini dijelaskan tentang metode, pendekatan, dan teknik pengumpulan data yang akan digunakan pada penelitian yang akan dilakukan.

\section{Bab IV Hasil dan Pembahasan PenElitian}

Bab hasil dan pembahasan yaitu mendeskripsikan dan memaparkan hasil penelitian yang telah dilakukan dan pembahasan mengenai data yang telah diperoleh secara detail dan data-data yang relevan. 


\section{Bab V Penutup}

Pada bab penutup berisi tentang kesimpulan dari hasil penelitian yang dikaji dengan data nyata di lapangan dan saran dari penulis mengenai hasil penelitiannya. 


\section{BAB II}

\section{TINJAUAN PUSTAKA DAN LANDASAN TEORITIS}

\subsection{Tinjauan Pustaka}

Eksistensi Tari Ronggeng Bugis di Sanggar Pringgadhing Plumbon Cirebon merujuk pada beberapa kajian pustaka atau penelitian-penelitian yang relevan mengenai Tari Ronggeng Bugis atau eksistensi sebuah seni tari dalam suatu daerah. Adapun sumber karya ilmiah yang terkait dengan judul penelitian ini diantaranya :

\subsubsection{Pembelajaran Tari Ronggeng Bugis di SMK N 1 Kedawung Kabupaten Cirebon (skripsi Wulan Mustikayani Universitas Pendidikan Indonesia 2013).}

Pembahasan dan isi penelitian ini memperoleh hasil sebagai berikut : Pada perencanaan pembelajaran Tari Ronggeng Bugis yang disusun oleh guru mata pelajaran seni budaya diterapkan model pendekatan yang lebih menekankan pada kemandirian, temuan baru, dan pengalaman langsung peserta didik dalam menirukan gerak untuk merangsang keaktifan belajar bagi peserta didik dalam kegiatan pembelajaran Tari Ronggeng Bugis. Proses pembelajaran Tari Ronggeng Bugis menggunakan pembelajaran kooperatif karena bekerja secara kelompok selain itu menerapkan peniruan gerak tari Ronggeng Bugis yang dilakukan guru mata pelajaran seni budaya kepada para siswa. Meskipun membuat kreativitas siswa kurang berkembang namun peserta didik mengalami perkembangan yang sangat baik dan sangat berantusias untuk mempelajari Tari Ronggeng Bugis. Perbedaan yang terdapat pada penelitian ini adalah dari segi topik yang akan 
dikaji, yaitu dalam penelitian ini membahas tentang pembelajaran Tari Ronggeng Bugis sedangkan penelitian saya tentang eksistensi Tari Ronggeng Bugis, sedangkan persamaannya terdapat pada objek yang akan dikaji yaitu sama-sama mengkaji seni tari Ronggeng Bugis.

\subsubsection{Komunikasi Ekspresif Tari Ronggeng Bugis Cirebon (skripsi Hanna Wisudawaty Universitas Islam Bandung 2009)}

Situasi Komunikasi Ekspresif Tari Ronggeng Bugis Cirebon tidak terlepas dari bunyi musik yang mengiringi yakni ketipung yang bertindak sebagai pemimpin pertunjukan, yang mengatur dan mengendalikan irama tabuhan yang disajikan diawal maupun diakhir pertunjukan. Peristiwa ekspresif dalam Tari Ronggeng Bugis Cirebon menyangkut tipe peristiwa, topik, fungsi atau tujuan, setting, partisipan, bentuk pesan seperti bahasa yang digunakan, isi pesan dan urutan tindak, serta kaidah dan norma interpretasi. Tari Ronggeng Bugis merupakan tipe peristiwa yang disajikan dalam bentuk hiburan-hiburan untuk menyambut tamu, hajatan dan kegiatan budaya lainnya. Topik yang diangkat dalam seni pertunjukan Tari Ronggeng Bugis Cirebon adalah masalah politik dalam hal terbentuknya pasukan telik sandi atau penyamaran seorang prajurit Cirebon. Fungsi Tari Ronggeng Bugis selain sebagai seni pertunjukan yang bersifat menghibur juga didalamnya terkandung suatu ajaran luhur bahwa kita hendaknya hidup sederhana, panarima, berkarya, ulet dan waspada selain itu juga memiliki sikap keperwiraan atau heroisme. Bahasa yang digunakan pada pertunjukan seni Tari Rongeng Bugis adalah bahasa non verbal yaitu berupa bentuk ekspresif, karakteristik gerakan, dan isyarat yang digunakan oleh penari 
Ronggeng Bugis Cirebon. Perbedaan yang tedapat pada penlitian ini adalah dari segi topik yang akan dikaji yaitu dalam penelitian ini mengangkat topik komunikasi ekspresif tari Ronggeng Bugis dan topik penelitian yang akan saya kaji adalah eksistensi tari Ronggeng Bugis, sedangkan persamaannya terdapat pada objek yang akan dikaji yaitu sama-sama mengkaji seni tari Ronggeng Bugis.

\subsubsection{Eksistensi Tari Opak Abang Sebagai Tari Daerah Kabupaten Kendal (Jurnal Harmonia Unnes Sellyana dan Wahyu Lestari 2012).}

Adapun hasil dari isi dan pembahasan penelitian ini adalah eksitensi tari Opak Abang sudah diakui oleh pemerintah kabupaten Kendal dan dapat dilihat, dari pemain Tari Opak Abang yang diberi kepercayaan oleh pemerintah kabupaten Kendal untuk tetap hadir memeriahkan panggung hiburan di Kendal. Pemain tari Opak Abang diikut sertakan untuk mengisi acara-acara separti acara tahunan pada acara rutin Kabupaten Kendal yaitu parade Kabupaten Kendal. Selain mengikuti pementasan, pemain tari Opak Abang juga tetap menjaga dan melestarikan perkembangan tari Obak Abang dengan memberikan pelatihan tari Opak Abang kepada masyarakat luas. Perbedaan yang tedapat pada penlitian ini dengan penelitian yang akan saya lakukan terdapat pada objek yang akan dikaji yaitu dalam penelitian ini mengambil objek Tari Opak Abang, dan objek penelitian yang akan saya ambil adalah Tari Ronggeng Bugis, sedangkan persamaannya terdapat pada topik, yaitu mengkaji topik tentang eksistensi. 


\subsubsection{Eksistensi Seni Pertunjukan Rakyat Di Daerah Kedu Jawa Tengah}

\section{(Jurnal Mudra oleh Nanik Sri Prihatini Institut Seni Indonesia}

\section{Surakarta 2012).}

Menyimak keberadaan seni pertunjukan rakyat di daerah Kedu sangat ditentukan oleh masyarakat pendukungnya. Kedinamisan masyarakatnya mengakibatkan adanya bermacam peran pada seni pertunjukan yang berdampak pada tindakan kreatif yang dilakukan para seniman menyebabkan hadirnya bentuk-bentuk seni pertunjukan yang menjadi spsesifik. Kelangsungan hidup atau eksistensi seni pertunjukan rakyat di daerah kedu utamanya didukung oleh berbagai kegiatan untuk upacara maupun non upacara baik yang bersifat perorangan maupun kelompok. Selain itu juga dikatakan pula dengan cara alih generasi yang disengaja maupun tidak.

Terdapat persamaan dan perbedaan mengenai topik yang akan peneliti kaji. Persamannya adalah sama-sama meneliti tentang kajian eksitensi suatu seni pertunjukan. Perbedaannya terdapat pada objek penelitian, dalam penelitian ini objek yang diambil adalah seni pertunjukan rakyat sedangkan objek penelitian yang akan saya ambil adalah Tari Ronggeng Bugis.

\subsection{Landasan Teoritis}

\subsubsection{Eksistensi}

Menurut Kierkegaard "eksistensi” dalam filsafat eksistensialisme memiliki arti sebagai suatu kepedulian terhadap eksistensi manusia. Purwodarminto (2012) dalam Heni dan Wahyu Lestari, eksistensi mengandung pengertian tentang keberadaan suatu kegiatan yang terus-menerus dilakukan, sehingga kegiatan terus 
berjalan dengan lancar. Menurut Durkheim (dalam Nainul 1990) arti eksistensi (keberadaan) adalah "adanya". Dalam filsafat eksistensi, istilah eksistensi diberikan arti baru, yaitu sebagai gerak hidup dari manusia konkret.

Menurut (Abidin dalam jurnal Maritfa Nika dan Muhammad Mukti 2013), eksistensi adalah suatu proses yang dinamis, suatu "menjadi" atau "mengada". Ini sesuai dengan asal kata eksistensi itu sendiri yakni existere, yang artinya keluar dari, "melampaui" atau "mengatasi". Jadi eksistensi tidak bersifat kaku dan terhenti, melainkan lentur atau fleksibel dan mengalami kemajuan atau kemunduran, tergantung pada kemampuan mengaktualisasikan potensipotensinya.

Jadi eksitensi yaitu dimana setiap hal atau kegiatan tentang makhluk hidup dan aktivitasnya yang dapat dilihat secara jelas bagaimana keberadaan itu dapat hidup disekitarnya dan dapat berjalan dengan lancar baik itu mengalami kemajuan atau bahkan dapat mengalami kemunduran namun pada kenyataanya kegiatan tersebut sudah hidup bahkan dapat berjalan secara terus-menurus maka itu dikatakan eksis atau ada.

Menurut Jazuli (2016) eksistensi tari dalam suatu masyarakat beserta kebudayaan yang melingkupinya tidak muncul, dan tidak hadir secara tiba-tiba, melainkan melalui proses ruang dan waktu. Ruang biasanya terkait dengan peristiwa dan kepentingan (performa) dan sistem nilai, sedangkan waktu terkait dengan proses produksinya (penciptaan). Misalnya sebuah tari diciptakan untuk kepentingan identitas suatu daerah, maka performanya akan mencerminkan visi dan misi serta sistem nilai yang ada dan berkembang di daerah yang bersangkutan. 
Sistem nilai adalah sesuatu yang menjadi pemikiran, keinginan, tujuan dari daerah yang memiliki identitas tersebut. Sama halnya dengan Tari Ronggeng Bugis yang dijadikan salah satu tari identitas daerah Cirebon melalui sejarahnya sehingga terciptalah tari Ronggeng Bugis sebagai tari Telik Sandi.

\subsubsection{Pengertian tari}

Royce terjemahan widaryanto (2012) mengatakan tari adalah seni yang paling tua. Dapat juga dikatakan bahwa tari lebih tua dari seni itu sendiri. Tubuh manusia membuat pola gerak dalam ruang dan waktu menjadikan tari itu unik diantara kesenian lainnya dan menerangkan proses waktu yang telah lama dilalui beserta universalitasnya.

Murgiyanto (1986) mengatakan bahwa tari merupakan suatu bagian dari seni pertunjukan yang harus ditata dan disusun rapih secara estetis sedemikian rupa sehingga mampu menyentuh batin para penontonya atau penikmatnya.

Menurut Sumaryono (2011) tari secara sederhana merupakan gerak-gerak tubuh manusia yang ritmis dan indah. Gerak-gerak ritmis atau yang disebut dengan gerak berirama adalah gerak-gerak yang memiliki keteraturan dan keselarasan dengan ketukan atau irama. Sedangkan ritmis dan irama berkaitan dengan unsur musikal yang menjadi pengiringnya.

Tari sebagai aktivitas pengalaman seni sangat menekankan pentingnya pengembangan kreativitas, apresiasi, dan ekspresi secara luas. Ketiga pengembangan tersebut merupakan kebutuhan integrative setiap orang. Kebutuhan kreatif tercermin dalam kegiatan olah rasa, olah hati, olah cipta, dan olah raga yang berimplikasi pada kesehatan jasmani dan rohani (Jazuli, 2008). 
Tari sebagai karya seni merupakan alat ekspresi perasaan manusia yang berasal dari pengembangan imajinasi dan diberikan bentuk melalui media gerak. Tari adalah bentuk simbolik yang bisa menampakkan pandangan pribadi penciptanya, daerahnya atau budayanya, yang bila disajikan sebagai objek seni menjadi sebuah pengalaman estetis bagi pengamatnya. Oleh karenanya tari mampu menjadi sarana komunikasi seorang seniman (pencipta-pelaku) kepada orang lain (pengamat/penonton) (Jazuli 2016).

Menurut Yermiandhoko (2013) Tari adalah suatu kegiatan menggerakkan tubuh secara ritmis tetapi bukan hanya untuk bersenang-senang. Tari merupakan bagian dari budaya masyarakat yang mempunyai tujuan tertentu dalam penciptaanya. Tari digunakan sebagai sarana dalam upacara keagamaan sejak berabad-abad lalu. Penggunaan tari untuk hiburan lazim dipakai pada masa sekarang karena dorongan dari perkembangan zaman dan kepentingan manusia. Tari juga digunakan dalam pembelajaran formal dengan maksud agar memberikan keseimbangan antara intelektualitas dan sensibilitas, rasionalitas dan irasionalitas, serta akal pikiran dan kepekaan emosi.

Tari dapat juga dikatakan sebagai alat komunikasi kekhalayak umum lewat gerak yang pesannya tersirat. Oleh karena itu, penggarapan suatu tari dipengaruhi oleh jenis-jenis pola garapan yang dikuasai oleh koreografer. Pola garap tari terbagi menjadi dua yaitu, tari tradisional dan tari kreasi (Jazuli 2016).

Menurut Jazuli (1994) bentuk tari dalam pola garapannya dibagi menjadi dua yaitu tari tradisional dan tari kreasi. Tari tradisional adalah sebuah tarian yang lahir, tumbuh, dan berkembang dalam suatu masyarakat yang kemudian 
diturunkan atau diwariskan secara terus menerus dari generasi kegenerasi. Dengan kata lain, selama tarian tersebut masih sesuai dan diakui oleh masyarakat pendukungnya maka tarian itu termasuk tari tradisional. sedangkan tari kreasi pengertiannya adalah jenis tari yang koreografinya masih bertolak dari tari tradisional atau pengembangan dari pola-pola tari yang sudah ada. Terbentuknya tari kreasi karena dipengaruhi oleh gaya tari dari daerah/negara lain maupun hasil kreativitas penciptanya. Murgiyanto (1986) mengatakan bahwa tari tradisi memang memiliki aturan-aturan yang ketat, tetapi tidak berarti tari tradisi itu tidak memberikan kesempatan bagi berkembangnya daya kreasi penarinya. Dewasa ini tidak sedikit tari-tarian upacara dan pergaulan yang telah berkembang menjadi tari pertunjukan. Untuk itu dibutuhkan pengetahuan tentang komposisi tari. Bagi imajinasi yang subur, sesungguhnya tradisi menyediakan bahan-bahan yang berlimpah untuk diciptakan kembali.

Tari diciptakan dengan tujuan untuk dikomunikasikan kepada para penikmatnya, oleh karena itu, tari tidak hanya sekedar rangkaian gerak, tetapi mempunyai bentuk, wujud, kesatuan dan ciri khas. Bentuk dapat dikatakan sebagai organisasi dari kekuatan-kekuatan sebagai hasil dari struktur internal dari tari. Bentuk memberi satu keteraturan dan keutuhan dari tari (Widyastutieningrum dan Wahyudiarto 2014). Tari adalah ekspresi jiwa dan perasaan manusia yang diungkapkan lewat gerak-gerak ritmis yang indah yang telah mengalami stilisasi maupun distorsi (Hadi, 2011:37).

Selain itu menurut Jazuli (1994) tari mempunyai arti penting dalam kehidupan manusia, karena tari dapat memberikan berbagai manfaat, misalnya 
seperti dijadikan hiburan dan sarana komunikasi. Mengingat kedudukannya itu tari dapat hidup, tumbuh, dan berkembang sepanjang zaman sesuai dengan perkembangan kebudayaan manusianya. Dengan kata lain, bahwa perkembangan maupun perubahan pada tari sangat ditentukan oleh masyarakat pendukungnya. Perubahan pola pikir masyarakat akan berpengaruh terhadap fungsi dan struktur tari, karena tari senantiasa menyesuaikan dengan konteksnya.

\subsubsection{Bentuk Pertunjukan}

Tari sebagai repretoar (sajian pertunjukan) merupakan hasil dari proses kreatif, baik dari kreasi koreografer (orang yang mencipta tari), penari (orang yang mengekspresikan tari), dan orang yang memiliki keahlian dalam tata rupa pelengkap sajian tari. Inilah yang membuktikan tari sebagai seni kolektif, karena orang-orang yang terlibat dalam satu repertoar tari harus mampu bekerjasama secara kolektif untuk mewujudkan pertunjukan tari yang bisa memberikan kepuasan dan daya pesona kepada penonton. Terdapat elemen-elemen bentuk pertunjukan dalam tari sebagai berikut :

\subsubsection{Pelaku}

Menurut Murgiyanto (1986) dalam seni pertunjukan, terdapat seniman pelaku dan seniman pencipta. Jumlah seniman pelaku selalu lebih banyak dibandingkan seniman penciptanya. Demikian pula halnya dalam seni tari, jumlah penari lebih banyak daripada pencipta atau penata tari.

Menurut Jazuli (2016) orang-orang yang terlibat dalam aktivitas tari dapat ditinjau secara tekstual (penciptaan) dan kontekstual (penyajian). Secara tekstual terdiri dari unsur penari, pengiring (musisi dan penata musik, pencipta/koreografer 
(creative actrist), dan kelengkapan pendukung sajian tari. Secara kontekstual terdiri dari penyelengara (biasanya berbentuk kepanitiaan atau pengurus), pengguna (apresiator dengan berbagai jenisnya), pendukung (semua yang terlibat dalam pertunjukan tari), dan penunjang (sarana prasarana dalam tari).

Menurut Hadi (2011) dalam koreografi adanya keterkaitan atau hubungan antara penata tari (koreografer) dan penari yang dapat menentukan keberhasilan suatu pertunjukan tari. Seorang penata tari dan penari harus saling memahami fungsi dan perannya sendiri-sendiri. Koreografer adalah seorang penata, penyusun, atau menggarap keseluruhan komposisi tari. Berbeda dengan seorang penari, aktivitas seorang penari menggantungkan tubuhnya sendiri sebagai satusatunya alat berekspresi, artinya dengan tubuhnya sendiri ia dapat menghasilkan gerak . Jadi setiap tarian pasti memiliki fungsi dan tujuannya, kemudian berkaitan pula dengan alasan mengapa tarian ini diciptakan, dan akan dijadikan tarian seperi apa, dan berapa jumlah penarinya.

\subsubsection{Gerak}

Gerak adalah pertanda kehidupan. Reaksi pertama dan terakhir manusia terhadap hidup, situasi dan manusia lainnya dilakukan dalam bentuk gerak. Perasaan puas, kecewa, cinta, takut, dan sakit selalu dipahami lewat perubahanperubahan yang halus dari gerakan tubuh kita. Hidup berarti bergerak dan gerak adalah bahan baku tari (Murgiyanto 1986).

Menurut Jazuli (1989) Gerak merupakan unsur utama dalam tari, yang di dalamnya mengandung unsur tenaga, ruang, dan waktu. Maksudnya adalah untuk menimbulkan gerak yang indah dan mempunyai kekuatan sehinga mampu 
mengubah suatu sikap dari anggota tubuh. Perubahan sikap yang terjadi dikatakan gerak dalam seni tari yaitu merupakan hasil proses pengolahan dari gerak yang telah mengalami stilisasi atau pengolahan gerak.

Gerak tari muncul karena ada tenaga yang menggerakkan, dan tubuh manusia sebagai alat (instrument) untuk bergerak. Gerak ditinjau dari penggunaan tenaga (penyebab gerak) mencakup intensitas, aksen atau tekanan, dan kualitas. Intensias adalah banyak sedikitnya tenaga yang digunakan dalam sebuah gerak. Aksen atau tekanan adalah bagian-bagian titik gerakan yang terjadi karena penggunaan tenaga yang tidak rata, artinya ada gerakan yang mengunakan tenaga sedikit ada pula yang banyak. Kualitas gerak dapat dibedakan antara lain atas yang bersifat ringan atau berat, lepas atau berbatas jelas, serba menghentak cepat, langsung atau tidak langsung dalam menuju titik akhir dari frase gerak. Ketiga elemen gerak yaitu tenaga, ruang dan waktu tidak pernah terpisah dalam gerak tubuh. Ketiganya terangkai secara khas sebagai penentu "kualitas gerak" (Jazuli 2016:41-42).

Gerak dalam tari dikategorikan menjadi dua yaitu gerak maknawi dan gerak murni. Gerak maknawi adalah gerak yang mengungkapkan makna secara eksplisit dan mengandung suatu arti. Contohnya gerak orang bercermin, menangis, dan gerak-gerak tari dalam aktivitas sehari-hari seperti aktivitas nelayan dan masih banyak gerak-gerak maknawi lainnya. Gerak murni adalah gerak yang fungsinya hanya untuk keindahan semata dan tidak memiliki arti apapun atau maksud tertentu. Gerak murni tidak memiliki arti khusus dan hanya sebagai penghias dan pengindah dalam tarian. Contohnya dalam bentuk tangan 
ada nyekiting, nyempurit, gerakan pacak gulu pada leher, dan pada kaki misalnya nyelekenthing dan masih banyak lagi (Kusnadi 2009)

Menurut Widyastutieningrum dan Wahyudiarto (2014) mengatakan bahwa gerak merupakan gejala yang paling primer dari kehidupan manusia, dan gerak juga merupakan media yang paling tua dari manusia untuk menyatakan keinginan, atau merupakan bentuk refleksi spontan dari gerak batin manusia. Dalam koreografi, gerak adalah dasar ekspresi. Oleh sebab itu gerak dapat kita pahami sebagai ekspresi dari semua pengalaman emosional (Hadi 2011).

\subsubsection{Tata Busana dan Kostum}

Kostum tari yang baik bukan sekedar berguna sebagai penutup tubuh penari, tetapi merupakan pendukung desain keruangan yang melekat pada tubuh penari. Kostum tari mengundang elemen-elemen wujud, garis, warna, kualias, tekstur dan dekorasi. Kostum tari dapat menampilkan ciri-ciri khas suatu bangsa atau daerah tertentu dan membantu terbentuknya desain keruangan yang menopang gerakan penari. Selanjutnya kostum dapat membantu mengubah penampilan seorang penari misalnya menjadi karakter lain (Murgiyanto 1986:9899).

Tata busana tari, semula pakaian yang dikenakan oleh para penari adalah pakaian sehari-hari. Dalam perkembangannya, pakaian tari telah disesuaikan dengan kebutuhan tarinya. Fungsi busana tari adalah untuk mendukung tema atau isi tari, dan untuk memperjelas peran-peran dalam suatu sajian tari. Busana tari yang baik bukan hanya sekedar untuk menutup tubuh semata, melainkan juga 
harus dapat mendukung desain ruang pada saat penari sedang menari (Jazuli 2016:61)

\subsubsection{Tata Rias}

Tata rias bagi seorang penari merupakan hal yang sangat penting. Rias juga merupakan hal yang paling peka dihadapan penonton, karena penonoton biasanya sebelum menikmati tarian selalu memperhatikan wajah penarinya, baik untuk mengetahui tokoh/peran yang sedang dibawakan maupun untuk mengetahui siapa penarinya. Misalnya apakah penarinya tampak cantik atau gagah, apakah rias penari mencerminkan karakter peran yang sedang dilakukan, dan sebagainya. Fungsi rias antara lain adalah untuk mengubah karakter pribadi menjadi karakter tokoh yang sedang dibawakan, untuk memperkuat ekspresi, dan untuk menambah daya tarik penampilan (Jazuli, 2016:61).

Perlu diperhatikan bahwa tata rias panggung (untuk pertunjukan) berbeda dengan rias untuk sehari-hari. Untuk pemakaian rias sehari-hari kita harus selalu menyesuaikan dengan situasi lingkungan. Misalnya cukup dengan polesan dan garis-garis tipis. Lain halnya dengan rias panggung, yakni selain harus lebih tebal karena adanya jarak anatara penari dan penonton yang sering agak berjauhan, juga harus menyesuaikan karakter tokoh atau peran yang dibawakan (Jazuli, 1994).

\subsubsection{Musik iringan}

Secara tradisional erat sekali hubungan musik dengan tari. Keduanya berasal dari sumber yang sama yaitu dorongan atau naluri ritmis manusia. Selain sebagai sarana ekspresi, suara manusia juga dapat membangkitkan rangsangan 
gerak pada tubuh manusia itu sendiri. Dalam bentuk awalnya iringan tari datang dari diri si penari sendiri (internal) tetapi dalam perkembangan lebih lanjut iringan tari sering datang dari luar tubuh penari (eksternal) atau dilakukan oleh orang lain (pemusik). Dalam bentuknya yang murni, tari dan musik mampu menggugah rasa hati tanpa harus menimbulkan asosiasi-asosiasi yang memaksa kita mebuat interpretasi yang kongkret. Hubungan sebuah tarian dengan musik pengiringnya dapat terjadi pada aspek bentuk, gaya, ritme, suasana, atau gabungan dari aspekaspek itu (Murgiyanto, 1986:43-44).

Musik dan tari merupakan pasangan yang tidak dapat dipisahkan satu dengan yang lainya. Semula manusia menggunakan suaranya dengan teriakan, jeritan dan tangisan guna mengungkapkan perasaannya, seperti perasan gembira, takut, terharu, marah, dan sebagainya. Curt Sachs dalam bukunya World History of The Dance mengatakan, bahwa pada zaman pra-sejarah andaikata musik dipisahkan dari tari, maka musik itu tidak memiliki nilai artistik apapun (Jazuli, 2016:60).

Ada dua bentuk iringan tari yaitu iringan internal dan iringan eksternal. Iringan internal artinya iringan tari yang berasal dari penarinya sendiri. Iringan internal dapat berupa suara teriakan atau nyanyian dari penari dan suara-suara karena gerakan penari itu sendiri seperti tepuk tangan, hentakan kaki ke lantai serta bunyi-bunyian lain yang timbul karena pakaian atau perhiasan yang dikenakannya. Iringan eksternal artinya iringan tari dimainkan oleh orang-orang bukan penari (Murgiyanto, 1984: 43-44). 


\subsubsection{Tempat Pertunjukan}

Setiap pertunjukan seni pasti membutuhkan waktu dan tempat untuk menampilkan sebuah pertunjukan seni itu sendiri. Menurut Jazuli (2016:61) tempat pentas suatu pertunjukan apa pun bentuknya selalu memerlukan tempat atau ruangan guna menyelenggarakan pertunjukan itu sendiri. Di Indonesia kita dapat mengenal bentuk tempat pertunjukan (pentas), seperti dilapangan terbuka atau arena terbuka, di pendapa, dan pemanggungan (staging). Pada tempat-tempat terbuka kita bisa menyaksikan pertunjukan tari yang diselenggarakan di halaman pura-pura Bali, pertunjukan tari tradisional di lingkungan rakyat sering dipergelarkan di lapangan terbuka, seperti bentuk seni pertunjukan di daerah pedalaman Kalimantan, Sulawesi, Irian Jaya, Maluku senantiasa diadakan di tempat-tempat terbuka. Lain halnya di kalangan bangsawan Jawa, pertunjukan kesenian sering diadakan di pendapa, yaitu suatu bangunan yang berbentuk joglo dan bertiang pokok empat, tanpa penutup pada sisi-sisinya.

Widyastutieningrum dan Wahyudiarto (2014) pada dasarnya ruang pentas dapat dibedakan menjadi dua golongan besar. Pertama pentas proscenium di mana penonton hanya dapat melihat dan mengamati pementasan tari dari satu sisi depan saja. Dimensi ketiga atau kedalaman ruangan memang harus tetap diusahakan, tetapi karena desain gerak hanya ditunjukan kesatu sisi, hasilnya berbeda jika menata tari untuk sebuah pentas arena, dimana penonton dapat mengamati pementasan tari dari ketiga sisi atau bahkan dari segala arah (pentas melingkar). 


\subsubsection{Apresiator}

Apresiator adalah penikmat seni yang berasal dari kalangan seniman, kritikus, Maecenas atau patron, pecinta seni, ahli seni, guru seni, dan warga masyarakat umumnya. Mereka berapresiasi terhadap tari untuk memenuhi maksud dan tujuan tertentu. Sebab berapresiasi dapat memberi kepuasan intelektual, mental, dan spiritual seseorang sehingga memperoleh pengalaman menyerap, menyaring, menyingkap, menafsirkan dan menanggapi gejala estetik pada karya tari (Jazuli 2016:40).

Menurut Hadi (2011) penonton adalah sebagai audience, dalam hal ini dapat dibedakan menjadi dua kategori. Pertama, adalah penonton yang bertujuan melihat pertunjukan atau koreografi sebagai santapan estetis yang berhubungan dengan tangkapan indera, sehinga penonton dalam kategori ini lebih kepada "kepuasan estetis" belaka, yaitu memberi komentar tontonan dengan latar belakang pengalaman hanya sebagai penonton saja. Sementara kategori kedua adalah penonton sebagai pengamat yang mampu membahas (able to discuss) atau seolah bertindak sebagai "kritikus". Dalam pemahaman koreografi sebagai produk, penonton sebagai pengamat atau kritikus sangat diperlukan untuk membantu kemajuan produksi pertunjukan. Seorang kritikus dibutuhkan karena dengan pengamatannya yang akan lebih teliti dan sudah terlatih, selain itu pikiran yang cerdas, serta perasaan yang peka, maka komentarnya atau pembahasannya akan membantu memahami pengalaman artistik.

Keberhasilan suatu karya seni bisa dilihat dari berapa banyak penonton atau apresiator atau penikmat seni yang datang untuk melihat pertunjukan 
tersebut. Tentu berhubungan dengan seberapa besar eksistensinya dimasyarakat luas, bukan hanya eksis di daerah tempat pertunjukan seni itu berdiri namun di luar dari itu, maka penonton merupakan salah satu hal penting dalam penentu diakui dan diterimanya kesenian itu di dalam lingkungan masyarakat sekitar.

\subsubsection{Kerangka Berfikir}

Tari Ronggeng Bugis merupakan tari tradisi yang sejarah, fungsi dan bentuk pertunjukannya tidak banyak diketahui oleh banyak kalangan masyarakat luas. Berdasarkan kenyataan yang ada, dalam penelitian ini peneliti ingin mengungkap kembali sejarah, bentuk pertunjukan, hingga eksistensi Tari Ronggeng Bugis yang ada di Sanggar Pringgadhing.

Maka untuk mengetahui seberapa besar atau luasnya eksistensi Tari Ronggeng Bugis, dalam hal ini peneliti akan membahas mengenai sejarah, upaya untuk mempertahankan eksistensi, dengan adanya kerjasama antara Sanggar Pringgadhing, Dinas Budaya Pariwisata Pemuda dan Olahraga (DISBUDPARPORA) Kabupaten Cirebon, dan sekolah yang mengajarkan Tari Ronggeng Bugis, Kemudian dalam bentuk pertunjukannya, Tari Ronggeng Bugis dapat dilihat dari beberapa elemen atau aspek bentuk pertunjukan yaitu pelaku, gerak, tata busana dan kostum, tata rias, musik iringan, tempat pertunjukan, dan yang terakhir adalah apresiator. Maka dengan adanya kerangka berfikir ini akan

diketahui Eksistensi Tari Ronggeng Bugis di Sanggar Pringgadhing Plumbon Cirebon. 


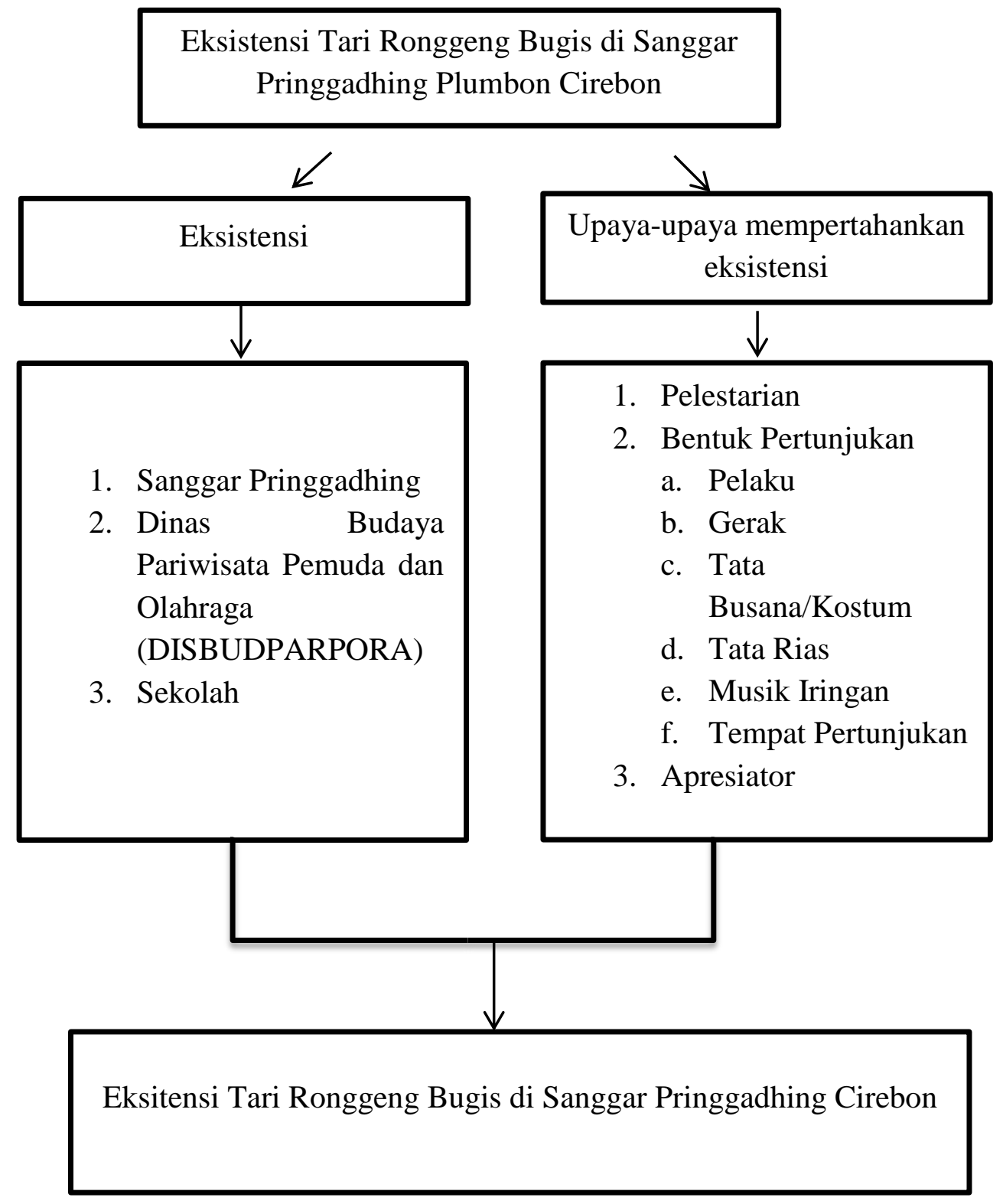




\section{BAB III \\ METODE PENELITIAN}

Penelitian pada hakikatnya merupakan suatu upaya untuk menemukan kebenaran atau untuk lebih membenarkan kebenaraan. Usaha untuk mengejar kebenaran dilakukan oleh para filsuf, peneliti, maupun oleh para praktisi melalui model-model tertentu (Moleong, 2010:49)

Menurut kamus Webster's New International, penelitian adalah penyelidikan yang berhati-hati dan krisis dalam mencari fakta dan prinsip-prinsip suatu penyelidikan yang amat cermat untuk menetapkan sesuatu. Penelitian dengan menggunakan metode ilmiah (scientific method) disebut penelitian ilmiah (scientific research) dengan dua unsur penting, yaitu unsur pengamatan dan unsur nalar atau penteorian. Konsep "penteorian metode kualitatif" merujuk pada keterjalinan antara teori dengan metode. Dalam konteks ini, teori dan metode dilihat sebagai dua hal yang tidak dapat dipisahkan (insparabel) (Ikbar 2012:173174).

Menurut Sugiyono (2010) secara umum metode penelitian diartikan sebagai cara ilmiah untuk mendapatkan data dengan tujuan dan kegunaan tertentu. Metode penelitian pendidikan dapat diartikan sebagai cara ilmiah untuk mendapatkan data yang valid dengan tujuan dapat ditemukan, dikembangkan, dan dibuktikan, suatu pengetahuan tertentu sehingga pada gilirannya dapat digunakan untuk memahami, memecahkan, dan mengatisipasi masalah dalam bidang pendidikan. 


\subsection{Pendekatan Penelitian}

Pendekatan penelitian ini menggunakan pendekatan kualitatif yang berupaya untuk memperoleh makna dari pandangan subjek yang diteliti atas dasar makna yang dibentuk dari aktivitas subjek itu sendiri dalam kesehariannya. Secara garis besar dapat dinyatakan bahwa metode penelitian kualitatif adalah metode pengkajian atau metode penelitian suatu masalah yang tidak didesain atau dirancang menggunakan prosedur-prosedur statistik (Sutopo dalam Maryono 2015). Pendekatan kualitatif merupakan pendekatan penelitian yang berlandaskan fenomenologi dan paradigma konstruktivisme dalam mengembangkan ilmu pengetahuan (Ikbar 2012).

Menurut Subroto dalam Maryono (2015) validitas keputusan atau hasil simpulan-simpulan mengenai suatu makna dapat diwujudkan dari deskripsi yang tegas, bersama-sama dengan orang lain dalam konteks intersubjektif yang di dalamnya termasuk pula interpretasi peneliti. Pada umumnya ilmu-ilmu kebudayaan ataupun ilmu-ilmu humaniora lebih banyak menggunakan metode kualitatif.

Maryono (2015) mengatakan bahwa metode penelitian kualitatif bersifat holistik yang menempatkan dalam kajian seni pertunjukan yaitu terbentuknya akselerasi tiga komponen yaitu seniman sebagai faktor genetik, karya seni sebagai faktor objektifnya, dan masyarakat faktor afektifnya yang bertindak sebagai penghayat atau penikmat seni. Terkait dengan kajian seni pertunjukan dengan metodologi kualitatif, tampak bahwa masing-masing faktor telah menyatu dalam koridor holistik. Harapan dengan adanya kajian kualitatif terhadap keterkaitan tiga 
faktor secara holistik tersebut yaitu : seniman penyusun tari sebagai kajian faktor genetik, karya seninya sebagai faktor objektif, dan masyarakat ikut berperan sebagai penghayat kajian faktor afektif yang dapat mengungkap makna seni pertunjukan secara utuh dan lengkap.

\subsection{Lokasi dan Sasaran Penelitian}

\subsubsection{Lokasi Penelitian}

Dalam penelitian ini, peneliti mengambil lokasi di Sanggar Pringgadhing Plumbon Cirebon Jawa Barat. Alasan peneliti memilih lokasi ini karena Tari Ronggeng Bugis berada di Sanggar Pringgadhing dan penciptanya yaitu bapak Handoyo (alm) yang merupakan pendiri Sanggar Pringgadhing.

\subsubsection{Sasaran penelitian}

Sasaran penelitian ini adalah Eksistensi Tari Ronggeng Bugis di Sanggar Pringgadhing Cirebon. Kajiannya adalah tentang bentuk pertunjukan Tari Ronggeng Bugis di Sanggar Pringgadhing Cirebon dan Eksistensi Tari Ronggeng Bugis di Sanggar Pringgadhing Cirebon

\subsubsection{Teknik Pengumpulan Data}

Teknik pengumpulan data merupakan langkah yang paling utama dalam penelitian, karena tujuan utama dari penelitian adalah mendapatkan data. Tanpa mengetahui teknik pengumpulan data, maka penelitian tidak akan mendapatkan data yang memenuhi standar data yang ditetapkan (Sugiyono 2010: 308).

\subsubsection{Observasi}

Observasi adalah pengamatan langsung terhadap suatu objek yang diteliti dengan menggunakan seluruh alat indera. Oleh sebab itu, observasi tidak hanya 
berkaitan dengan indera penglihatan saja tetapi observasi dapat dilakukan juga penciuman, pendengaran, peraba, dan pengecap (Arikunto 2010: 199). Observasi melibatkan tiga objek sekaligus, yaitu: a) lokasi tempat penelitian berlangsung, b) para pelaku dengan peran-peran tertentu, dan c) aktivitas para pelaku yang dijadikan objek penelitian (Ratna 2010: 220). Tahap observasi dalam penelitian harus menentukan dengan jelas batasan observasi sebagai fokus pengamatan sehingga hanya peristiwa yang diperlukan saja yang menjadi objek.

Pembagian observasi meliputi observasi atau pengamatan bebas (tidak berperan serta) dan pengamatan terlibat (berperan serta) Peneliti melakukan pengamatan terlibat atau disebut juga penelitian observasi partisipasi adalah observasi yang melibatkan peneliti atau observer secara langsung dalam kegiatan pengamatan di lapangan. Jadi peneliti bertindak sebagai observer, artinya peneliti merupakan bagian dari kelompok yang ditelitinya.

Dalam hal ini peneliti telah melakukan observasi dengan pengamatan bebas yang artinya peneliti tidak ikut berperan serta dalam kegiatan yang dilakukan objek penelitiannya namun peneliti menggunakan observasi berstruktur. Peneliti telah menyiapkan instrumen peneltian yang merupakan rincian pertanyaan untuk informan yang telah ditentukan, selain itu telah menyiapkan alat dan bahan yang akan membantu agar penlitian berjalan baik dan sesuai yang diharapkan. Hal-hal yang telah diobservasi yaitu desa Plumbon yang merupakan daerah Sanggar Pringgadhing, Sanggar Pringgadhing atau lokasi yang menjadi tempat penelitian dan sanggar yang memiliki tari Ronggeng Bugis, didalam sanggar hanya terdapat alat musik, studio musik, dan sound system untuk 
kebutuhan latihan. selain itu observasi juga dilakukan di rumah pemilik sanggar yang merupakan tempat penyimpanan kostum, properti dan asesoris tari, dan tempat pertunjukan yang akan dan biasa menampilkan Tari Ronggeng Bugis milik Sanggar Pringgadhing. Selain itu peneliti juga telah melakukan observasi secara langsung pementasan Tari Ronggeng Bugis Sanggar Pringgadhing yang diberikan kesempatan oleh Pemerintah Kota Cirebon untuk tampil dalam rangka mengisi acara Jaka Rara Kota Cirebon pada tanggal 21 Mei 2017.

\subsubsection{Wawancara}

Wawancara merupakan pertemuan dua orang untuk bertukar informasi dan ide melalui tanya jawab, sehingga dapat dikontruksikan makna dalam suatu topik tertentu. Wawancara digunakan sebagai teknik pengumpulan data apabila peneliti ingin melakukan studi pendahuluan untuk menemukan permasalahan yang harus diteliti, tetapi juga apabila peneliti ingin mengetahui hal-hal dari responden yang lebih mendalam (Seterberg dalam Sugiyono 2010: 317). Teknik pengumpulan data ini mendasarkan diri pada laporan tentang diri sendiri self-report, atau setidak-tidaknya pada pengetahuan dan atau keyakinan pribadi. Wawancara adalah sebuah dialog yang dilakukan oleh pewawancara untuk memperoleh informasi dari terwawancara (Arikunto 2010: 198). Seorang peneliti membutuhkan kecakapan, kepekaaan, konsentrasi, pemahaman interpersonal, wawasan, ketajaman mental, dan disiplin dalam berwawancara (Patton 2009: 182).

Teknik wawancara yang dilakukan dalam penelitian ini adalah wawancara terstruktur dan tidak terstruktur. Wawancara tidak terstruktur adalah wawancara 
yang hanya memuat garis besar yang ditanyakan dan biasanya jenis wawancara ini untuk penelitian kasus. Wawancara ini digunakan untuk penelitian pendahuluan dan penelitian lebih mendalam tentang responden. Wawancara terstruktur adalah wawancara yang disusun secara terperinci dan peneliti telah mengetahui dengan pasti tentang informasi apa yang akan diperoleh.

Dua teknik wawancara lain yaitu wawancara terbuka adalah wawancara yang berdasarkan pertanyaan yang tidak terbatas (tidak terikat) jawabannya. Wawancara tertutup yaitu wawancara yang berdasarkan pertanyaan yang terbatas jawabannya. Contohnya, wawancara yang menggunakan lembar daftar pertanyaan (questionaire) dengan jawaban yang telah dipersiapkan untuk dipilih, seperti setuju, tidak setuju, ya, tidak, sangat baik, cukup, kurang.

Pelaksanaan wawancara dilakukan secara langsung kepada terwawancara (informan). Ratna (2010: 228) memberikan gambaran bahwa informan yang baik adalah mereka yang menguasai permasalahan yang benar-benar diperlukan peneliti. Penguasaan yang dimaksudkan diperoleh melalui pengalaman yang sudah dilakukan selama bertahun-tahun sehingga mereka dapat menjelaskan tanpa memikirkannya. Alat dan bahan yang digunakan selama wawancara adalah buku, bolpoint, dan alat rekam dari handphone.

Wawancara yang telah dilakukan ditujukan kepada beberapa informan yang akan memberikan informasi mengenai eksistensi Tari Ronggeng Bugis yang mereka ketahui dan dapat membantu menjawab semua rumusan masalah dalam penelitian ini. Wawancara yang telah dilakukan menggunakan wawancara terbuka. Ada bebrapa narasumber yang berhasil diwawancarai atau dimintai 
informasi mengenai pengetahuannya tentang eksistensi Tari Ronggeng Bugis, narasumber utama yaitu ketua Sanggar Pringgadhing yang menyangkut tentang sejarah tari Ronggeng Bugis, perkembangan sampai eksitensi tari Ronggeng Bugis dan bentuk pertunjukan tari Ronggeng Bugis, pelatih di Sanggar Pringgadhing menyangkut tentang eksistensi tari Rongeng Bugis dan adakah kendala yang dirasakan dalam mengajarkan tari Ronggeng Bugis, kemudian ada penari tari Ronggeng Bugis mengenai bagaimana cara mereka ikut serta dalam mempertahankan eksistensi Tari Ronggeng Bugis di Sanggar Pringgadhing, kemudian mengenai perasaan mereka telah menarikan tari Rongeng Bugis dan bagaimana eksitensi tari Ronggeng Bugis menurut pandangan penarinya, Kepala Desa Plumbon mengenai letak demografis, keadaan penduduk Desa Plumbon dan eksistensi tari Ronggeng Bugis di Sanggar Pringgadhing, kepala bidang kebudayan Disbudparpora Kabupaten Cirebon menyangkut tentang eksistensi tari Ronggeng Bugis dan penonton mengenai seperti apa tari Rongeng Bugis yang mereka ketahui dan bagaimana eksistensi tari Ronggeng Bugis.

\subsubsection{Dokumentasi}

Teknik dokumentasi adalah mencari data mengenai hal-hal atau variabel yang berupa catatan, transkip, buku, surat kabar, majalah, prasati, notulen rapat, agenda dan sebagainya (Arikunto 2006:231).

Teknik dokumentasi digunakan untuk menggali data yang tidak dapat diperoleh melalui wawancara maupun observasi. Dokumentasi dapat berupa hasil tulisan-tulisan, foto-foto, dokumentasi peneliti, dan sebagainya yang berhubungan dengan penelitian ini. Bentuk dokumen dan arsip merupakan data yang 
menempati posisi penting pada penelitian kualitatif. Dokumen dan arsip dapat berupa tulisan yang sederhana hingga catatan yang lengkap, dan bisa berwujud gambar-gambar atau berupa benda-benda sebagai peninggalan.

Jenis-jenis dokumen atau arsip yang terdapat pada seni pertunjukan tari yaitu berupa rekaman tulisan diantaranya deskripsi tentang: ceritera, gerak, busana, dan notasi musik iringan. Dokumen atau arsip yang berupa gambar diantaranya : rekaman video tari, rekaman tari, dan foto-foto tari. Adapun dokumen atau arsip yang berupa benda diantaranya: kaset iringan tari atau kaset gendhing-gendhing beksan, kostum tari, alat-alat rias, relief-relief tari, dan properti tari seperti: pedang, tameng, tombak, watang, dhapdhap, gendewa, dan lainnya (Maryono 2011: 108-109).

Dokumentasi penelitian yang sudah didapatkan oleh peneliti meliputi: foto-foto pada saat tari Ronggeng Bugis pentas di beberapa acara yang di selenggarakan di tahun 2016-2017, dan juga video. Dokumentasi yang telah dilakukan peneliti yaitu berupa foto-foto yang meliputi: foto ragam-ragam gerak tari Ronggeng Bugis, foto kostum tari Ronggeng Bugis, foto alat musik yang digunakan untuk mengiringi tari Ronggeng Bugis baik pada saat pementasan di atas panggung maupun pementasan dalam bentuk Helaran, dan video saat pertunjukan Tari Ronggeng Bugis berlangsung saat mengisi acara dalam pemilihan Jaka Rara Kota Cirebon yang berlangsung pada tanggal 21 Mei 2017. 


\subsection{Teknik Analisis Data}

Menurut Sugiyono (2010) analisis data adalah proses mencari dan menyusun secara sistematis data yang diperoleh dari hasil wawancara, catatan lapangan, dan dokumentasi dengan cara mengorganisasikan data ke dalam kategori, menjabarkan ke dalam unit-unit, memilih mana yang penting dan yang akan dipelajari, dan membuat kesimpulan sehingga mudah difahami oleh diri sendiri dan orang lain. Analisis data dalam penelitian kualitatif dilakukan sejak sebelum memasuki lapangan, selama di lapangan, dan setelah selesai di lapangan. Namun demikian analisis data dalam penelitian kualitatif lebih difokuskan selama proses di lapangan bersamaan dengan pengumpulan data (Sugiyono 2013: 336). Analisis data dalam penelitian eksistensi Tari Ronggeng Bugis di Sanggar Pringgadhing Cirebon adalah dengan reduksi data, penyajian data, dan penarikan kesimpulan.

\subsubsection{Reduksi data}

Mereduksi data berarti merangkum, memilih hal-hal yang pokok, memfokuskan pada hal-hal yang penting, mencari tema, pola dan membuang hal yang tidak perlu. Dengan demikian data yang telah direduksi akan memberikan gambar yang lebih jelas, dan mempermudah peneliti untuk melakukan pengumpulan data selanjutnya (Sugiyono 2010).

\subsubsection{Penyajian data}

Dalam penelitian kualitatif, penyajian data bisa dilakukan dalam bentuk uraian singkat, bagan, hubungan antar kategori, flowhart dan sejenisnya. Penyajian data yang paling sering digunakan dalam penelitian kualitatif adalah 
dengan teks yang bersifat naratif (Sugiyono 2010). Jadi tahap setelah reduksi data adalah penyajian data, yaitu setelah melakukan penyeleksian data kemudian data dipaparkan secara transparan dan jelas sesuai hasil penelitian yang telah dilakukan baik dengan cara observasi, wawancara maupun dokumtasi. Pemaparan data ini berbentuk deskriptif atau penggambaran yang dijelaskan dengan kata-kata yang telah disusun menjadi sebuah kalimat-kalimat yang baik dan baku.

\subsubsection{Penarikan kesimpulan}

Cara penarikan kesimpulan ini disebut logika, logika adalah ilmu pengetahuan (science) tetapi sekaligus juga merupakan kecakapan atau keterampilan (art) untuk berpikir secara tepat, dan teratur (Ikbar 2012). Dalam Sugiyono (2010) kesimpulan dalam penelitian kualitatif yang diharapkan merupakan temuan baru atau pembahasan baru dari hasil penelitian dan pembahasan yang sebelumnya belum pernah ada. Temuan dapat berupa deskripsi atau gambaran suatu objek yang sebelumnya masih tidak jelas sehingga setelah diteliti menjadi jelas, yang dapat berupa hubungan kausal atau interaktif, hipotesis atau teori. 


\section{BAB IV}

\section{HASIL PENELITIAN DAN PEMBAHASAN}

\subsection{Gambaran Umum Tempat Penelitian}

\subsubsection{Letak Geografis Desa Plumbon}

Desa Plumbon merupakan salah satu desa yang ada di Kecamatan Plumbon Kabupaten Cirebon. Desa Plumbon merupakan desa yang dekat dengan jalan pantura. Namun cukup jauh jika dari pusat kota Cirebon, yaitu berjarak 15 km, dan jarak dari ibu kota provinsi Jawa Barat Kota Bandung berjarak 203 km. Desa Plumbon mempunyai batas wilayah sebagai berikut, sebelah utara berbatasan dengan desa Pasanggrahan, sebelah selatan berbatasan dengan desa Purbawinangun. Sedangkan sebelah barat berbatasan dengan desa Pamijahan, dan sebelah timur berbatasan dengan desa Marikangen.

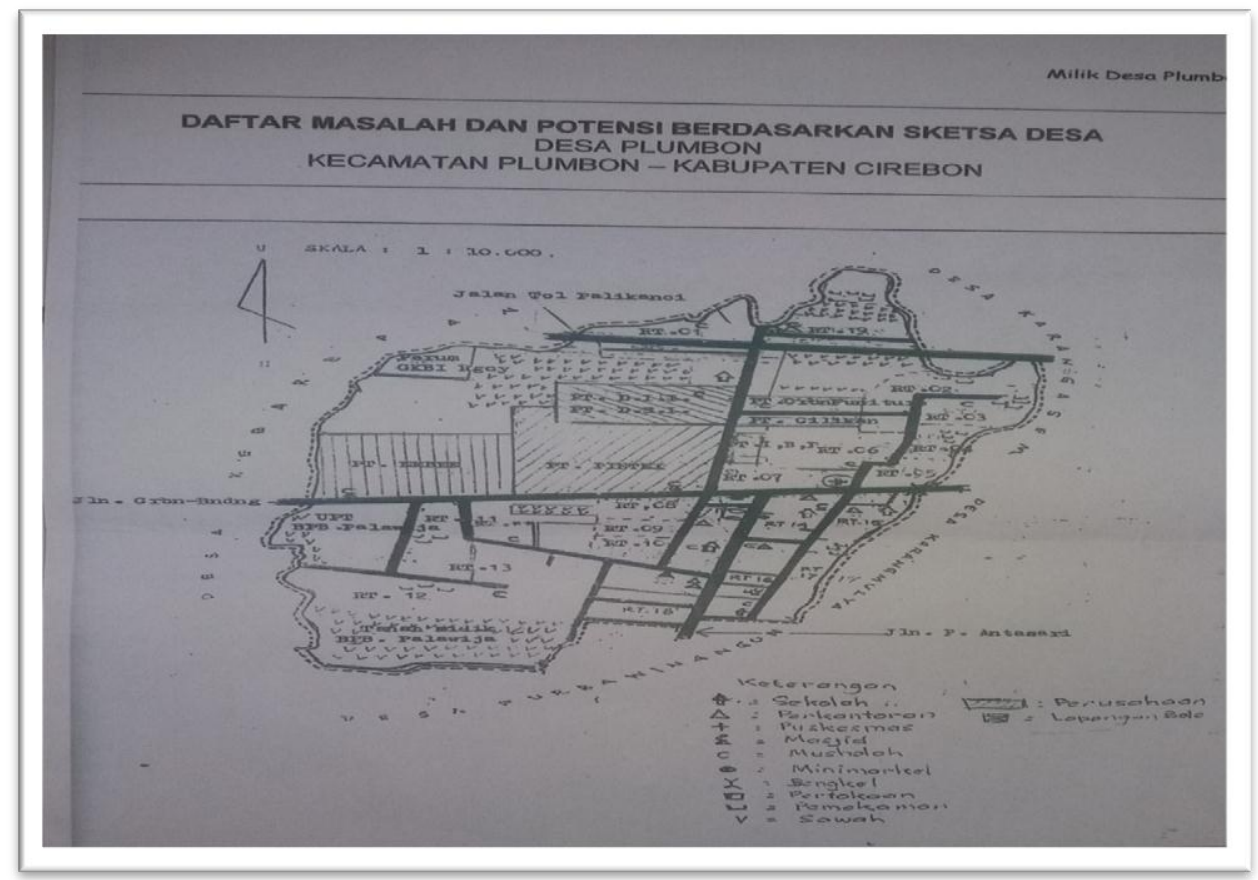

Gambar 1: Gambar Peta Desa Plumbon (Sumber: Dokumentasi penelitian Rosdiana, 2017) 


\subsubsection{Mata Pencaharian}

Jenis mata pencaharian penduduk Desa Plumbon sebagai berikut:

Tabel 4.1.2. Mata Pencaharian penduduk Desa Plumbon

\begin{tabular}{|r|l|l|l|}
\hline No & Mata Pencaharian & Jiwa & $\%$ \\
\hline 1. & Buruh Pabrik & 3100 & 66,9 \\
\hline 2. & Petani & 720 & 15,5 \\
\hline 3. & Wiraswasta & 500 & 10,7 \\
\hline 4. & PNS & 351 & 7,5 \\
\hline
\end{tabular}

(Sumber: Monografi Desa Plumbon sampai dengan bulan Mei 2017)

\section{Keterangan:}

Berdasarkan data pada tabel 4.1.2 jumlah penduduk Desa Plumbon keseluruhan yaitu 4.636 Jiwa, jumlah buruh pabrik dan petani menempati jumlah yang dominan yaitu sebanyak 3820 jiwa (82\%) dan sebagian kecil lainnya memilki profesi sebagai wiraswasta sebanyak 500 jiwa (10,7\%) dan yang paling sedikit persentasenya adalah Pegawai Negeri Sipil (PNS) yaitu sebanyak 351 jiwa berkisar 7,5\%.

Desa Plumbon merupakan daerah dataran rendah yang memiliki potensi alam berupa tumbuhan rotan. Hal ini dimanfaatkan oleh penduduk setempat sebagai lahan usaha kerajinan rakyat. Desa Plumbon dekat dengan kecamatan Plumbon dan di daerah kecamatan Plumbon merupakan salah satu sentral industri rotan terbesar di Indonesia, dan menyerap ribuan tenaga kerja hampir seluruh desa yang ada di kecamatan Plumbon termasuk desa Plumbon. Tak heran banyak di sepanjang jalan menuju desa Plumbon terdapat kerajinan rotan yang dipasarkan. 
Bahkan kerajinan rotan ini sebagaian besar diekspor ke luar negeri (wawancara dengan Kepala Desa Plumbon pada tanggal 24 Mei 2017). Kutipan wawancara dengan Kepala Desa Plumbon sebagai berikut:

"Mata pencaharian yang digeluti oleh warga di Desa Plumbon mayoritas jadi buruh pabrik, selain itu mata pencaharian yang dikerjakan oleh sebagian warga menjadi Pegawai Negeri Sipil (PNS), kemudian ada juga pedagang, karena disini banyak pabrik rotan dan jajanan, dan juga dekat dengan pasar. ada juga yang menggeluti pekerjaan di bidang seni yaitu seperti bapak Handoyo (alm) dan keluarga".

Menjadi seorang seniman ternyata dipilih oleh bapak Handoyo (alm) dan keluarganya sebagai mata pencaharian. Mereka membuat sebuah sanggar yang dapat menjadi tempat untuk melestarikan seni budaya daerah tersebut dan diberi nama Sanggar Seni Pringgadhing yang didirikan sejak tahun 1970 sampai saat ini tahun 2017 yang masih menjadi tempat usaha mereka.

\subsubsection{Bahasa}

Bahasa merupakan salah satu budaya yang dimiliki Indonesia. Setiap daerah pasti memiliki bahasa daerahnya masing-masing, begitu pula dengan Kabupaten/Kota Cirebon yang memiliki bahasa daerah sendiri yaitu bahasa Cirebon. Cirebon memang merupakan daerah bagian di Jawa Barat yang mayoritas berbahasa sunda.

Hampir disetiap daerah di wilayah Cirebon masyarakatnya memiliki logat bahasa Cirebon yang berbeda. Sementara itu beberapa kecamatan setiap desanya terkadang bahasanya berbeda. Misalnya bahasa Jawa Cirebon dan bahasa Sunda seperti halnya masyarakat Kecamatan Plumbon, Palimanan, Babakan, Ciledug, Gebang, Ciwaringin, dan seterusnya. 
Namun di masyarakat kota atau pusat kota Cirebon bahasa yang digunakan sehari-hari menggunakan bahasa Cerbon yang dicampur-campur dengan bahasa Indonesia. Bahasa Cerbon ialah bahasa yang dituturkan di pesisir utara Jawa Barat.

Bahasa Cirebon dipengaruhi juga oleh budaya Sunda karena keberadaannya yang masuk di Provinsi Jawa Barat dan berbatasan langsung dengan kebudayaan Sunda. Namun kosa kata yang ada berbeda dengan Sunda maupun Jawa. Masyarakat Cirebon menganggap kalau bahasa Cirebon masih produktif, dan sering digunakan oleh masyarakat dalam berkomunikasi dikehidupan sehari-hari.

\subsubsection{Potensi Seni dan Kesenian di Desa Plmbon}

Kesenian adalah bagian dari kebudayaan yang harus kita jaga dan lestarikan, karena kesenian merupakan salah satu kekayaan bahkan identitas bangsa Indonesia. Indonesia kaya akan seni dan budaya daerahnya, setiap daerah mempunyai keseniannya masing-masing, bahkan tak sedikit yang menjadikan kesenian tersebut sebagai salah satu identitas daerahnya.

Daerah Cirebon merupakan salah satu daerah yang memiliki banyak bentuk-bentuk kesenian baik seni musik, seni tari maupun wayang. Diantaranya sebagai berikut: dalam bidang seni musik ada tarling, gambus, qasidah, genjring dogdog dan yang lainnya. Sedangkan dibidang seni tari terdapat tari topeng, sintren, tayub, tari Ronggeng Bugis, dan yang lainnya. Selain dibidang musik dan tari tedapat pula wayang dan sandiwara. 
Kondisi kesenian yang ada di daerah Cirebon masih sangat diminati oleh masyarakat. Terbukti dengan adanya berbagai macam bentuk kesenian yang dimiliki sanggar-sanggar padepokan seni di Kabupaten Cirebon. Berikut data yang telah berhasil didapat mengenai macam-macam kesenian yang ada di kabupaten Cirebon yang telah diakui oleh pemerintah daerah setempat. Berikut daftar nama jenis kesenian grup dan sanggar yang ada di Kabupaten Cirebon.

Tabel 4.1.4.1: Data kesenian (seni musik) dan sanggar di Kabupaten Cirebon

\begin{tabular}{|c|c|c|c|}
\hline \multirow{2}{*}{$\begin{array}{c}\text { Jenis } \\
\text { Kesenian }\end{array}$} & \multicolumn{2}{|c|}{ Nama } & \multirow[t]{2}{*}{ Alamat } \\
\hline & Grup & Pimpinan & \\
\hline Tarling & Nada Budaya & $\begin{array}{c}\text { Sunarto } \\
\text { Martaatmadja }\end{array}$ & $\begin{array}{c}\text { Desa Setu Kulon } \\
\text { Kecamatan Weru } \\
\text { Kabupaten Cirebon }\end{array}$ \\
\hline Tarling & Primadona & Pepen Ependi & $\begin{array}{c}\text { Desa Jemares } \\
\text { Kecamatan } \\
\text { Klangenan Kabupaten } \\
\text { Cirebon }\end{array}$ \\
\hline Tarling & Candra Lelana & Maman Suparman & $\begin{array}{c}\text { Desa Arjawinangun } \\
\text { Kecamatan } \\
\text { Arjawinangun } \\
\text { Kabupaten Cirebon }\end{array}$ \\
\hline Tarling & Laras Gumelar & Juju Panjuju & $\begin{array}{c}\text { Desa Danawinangun } \\
\text { Kecamatan } \\
\text { Klangenan Kabupaten } \\
\text { Cirebon }\end{array}$ \\
\hline Tarling & Cakra Buana & Edi Muari & $\begin{array}{c}\text { Desa Gebang } \\
\text { Kecamatan Gebang } \\
\text { Kabupaten Cirebon }\end{array}$ \\
\hline
\end{tabular}




\begin{tabular}{|c|c|c|c|}
\hline Tarling & Putri Budaya & Yani Nurayani & $\begin{array}{l}\text { Desa Ujunggebang } \\
\text { Kecamatan Susukan } \\
\text { Kabupaten Cirebon }\end{array}$ \\
\hline Gambus & El Gamal & Marzuki & $\begin{array}{c}\text { Desa Ambulu } \\
\text { Kecamatan Losari } \\
\text { Kabupaten Cirebon }\end{array}$ \\
\hline Gambus & As-Syifaiyah & Haeru Sifa & $\begin{array}{c}\text { Desa Sigong } \\
\text { Kecamatan } \\
\text { Lemahabang } \\
\text { Kabupaten Cirebon }\end{array}$ \\
\hline Qasidah & Rafista Group & Heru Nasrudin & $\begin{array}{c}\text { Desa Blender } \\
\text { Kecamatan } \\
\text { Karangwareng } \\
\text { Kabupaten Cirebon }\end{array}$ \\
\hline Qasidah & Al-Qamariah & Eknom Komariah & $\begin{array}{c}\text { Desa Cilakahang } \\
\text { Kecamatan } \\
\text { Dukuhpuntang } \\
\text { Kabupaten Cirebon }\end{array}$ \\
\hline Qasidah & Sabala Grup & Muhasan & $\begin{array}{l}\text { Desa Gebang Udik } \\
\text { Kecamatan Gebang } \\
\text { Kabupaten Cirebon }\end{array}$ \\
\hline $\begin{array}{l}\text { Gamelan } \\
\text { Renteng }\end{array}$ & Pungkur Tamu & Tiswo Widodo & $\begin{array}{c}\text { Desa Pangkalan } \\
\text { Kecamatan Plered } \\
\text { Kabupaten Cirebon }\end{array}$ \\
\hline $\begin{array}{l}\text { Genjring } \\
\text { Dogdog }\end{array}$ & Swara Jati & Sumardi & $\begin{array}{c}\text { Desa Jatimerta } \\
\text { Kecamatan } \\
\text { Gunungjati } \\
\text { Kabupaten Cirebon }\end{array}$ \\
\hline
\end{tabular}

(sumber: Dispudparpora.cirebonkab.go.id 2017) 
Tabel 4.1.4.2: Data kesenian (wayang dan sandiwara) dan sanggar di Kabupaten Cirebon

\begin{tabular}{|c|c|c|c|}
\hline \multirow[t]{2}{*}{ Jenis Kesenian } & \multicolumn{2}{|r|}{ Nama } & \multirow[t]{2}{*}{ Alamat } \\
\hline & Grup & Pimpinan & \\
\hline Sandiwara & Budhi Suci & Rasmadi & $\begin{array}{c}\text { Desa Kartasura } \\
\text { Kecamatan } \\
\text { Kapetakan } \\
\text { Kabupaten } \\
\text { Cirebon }\end{array}$ \\
\hline Sandiwara & Jayabaya & H. Sulama HAdi & $\begin{array}{c}\text { Desa Kertasura } \\
\text { Kecamatan } \\
\text { Kapetakan } \\
\text { Kabupaten } \\
\text { Cirebon }\end{array}$ \\
\hline $\begin{array}{c}\text { Wayang Kulit } \\
\text { Purwa }\end{array}$ & Langen Purwa & H. Mansyur M & $\begin{array}{c}\text { Desa Gegesik } \\
\text { Kidul } \\
\text { Kecamatan } \\
\text { Gegesik } \\
\text { Kabupaten } \\
\text { Cirebon }\end{array}$ \\
\hline $\begin{array}{l}\text { Wayang Kulit } \\
\text { Purwa }\end{array}$ & Eka Mulya & Mulki & $\begin{array}{c}\text { Desa Kedung } \\
\text { Dawa } \\
\text { Kecamatan } \\
\text { Kedawung } \\
\text { Kabupaten } \\
\text { Cirebon }\end{array}$ \\
\hline Wayang Babad & Ogan Lopian & $\begin{array}{c}\text { Prof. Drs. H. Askadi } \\
\text { Sastrasuganda }\end{array}$ & $\begin{array}{c}\text { Desa Cangkring } \\
\text { Kecamatan } \\
\text { Plered } \\
\text { Kabupaten }\end{array}$ \\
\hline
\end{tabular}




\begin{tabular}{|c|c|c|c|}
\hline & & & Cirebon \\
\hline Wayang Wong & Purwa Galih & Suajan Priya & $\begin{array}{c}\text { Desa Astana } \\
\text { Kecamatan } \\
\text { Gunungjati } \\
\text { Kabupaten } \\
\text { Cirebon }\end{array}$ \\
\hline $\begin{array}{c}\text { Wayang Golek } \\
\text { Cepak }\end{array}$ & $\begin{array}{c}\text { Sekar } \\
\text { Penggalih }\end{array}$ & Timbul & $\begin{array}{c}\text { Desa } \\
\text { Cangkuang } \\
\text { Kecamatan } \\
\text { Babakan } \\
\text { Kabupaten } \\
\text { Cirebon }\end{array}$ \\
\hline Wayang Golek & Sangkuriang & Juju Ajuri & $\begin{array}{c}\text { Desa Cikulak } \\
\text { Kidul } \\
\text { Kecamatan } \\
\text { Waled } \\
\text { Kabupaten } \\
\text { Cirebon }\end{array}$ \\
\hline $\begin{array}{c}\text { Wayang Golek } \\
\text { Cepak }\end{array}$ & Budi Mulya & Dukadi & $\begin{array}{c}\text { Desa Surakarta } \\
\text { Kecamtan } \\
\text { Kapetakan } \\
\text { Kabupaten } \\
\text { Cirebon }\end{array}$ \\
\hline Wayang Golek & Cipta Mekar & Kartini Wijaya & $\begin{array}{c}\text { Desa Bojong } \\
\text { Gebang } \\
\text { Kecamatan } \\
\text { Babakan } \\
\text { Kabupaten } \\
\text { Cirebon }\end{array}$ \\
\hline
\end{tabular}

(sumber: Dispudparpora.cirebonkab.go.id 2017) 
Tabel 4.1.4.3: Data kesenian (seni tari) dan sanggar di Kabupaten Cirebon

\begin{tabular}{|c|c|c|c|}
\hline \multirow{2}{*}{$\begin{array}{c}\text { Jenis } \\
\text { Kesenian }\end{array}$} & \multicolumn{2}{|c|}{ Nama } & \multirow[t]{2}{*}{ Alamat } \\
\hline & Grup & Pimpinan & \\
\hline $\begin{array}{c}\text { Sanggar Seni } \\
\text { Tari }\end{array}$ & Pringgadhing & Handoyo MY & $\begin{array}{c}\text { Desa Plumbon } \\
\text { Kecamatan } \\
\text { Plumbon } \\
\text { Kabupaten } \\
\text { Cirebon }\end{array}$ \\
\hline $\begin{array}{c}\text { Sanggar Tari } \\
\text { Topeng }\end{array}$ & Purwa Kencana & $\begin{array}{c}\text { Nur'aini M. Irman, } \\
\text { S.Sn }\end{array}$ & $\begin{array}{c}\text { Desa Astana } \\
\text { Langgar } \\
\text { Kecamatan Losari } \\
\text { Kabupaten } \\
\text { Cirebon }\end{array}$ \\
\hline $\begin{array}{c}\text { Sanggar Tari } \\
\text { Topeng }\end{array}$ & Panji Arum Sari & Daimin & $\begin{array}{c}\text { Desa Kalianyar } \\
\text { Kecamatan } \\
\text { Panguragan } \\
\text { Kabupaten } \\
\text { Cirebon }\end{array}$ \\
\hline $\begin{array}{c}\text { Sanggar Tari } \\
\text { Topeng }\end{array}$ & Among Prawa & Hj. Juni & $\begin{array}{c}\text { Desa Gegesik } \\
\text { Wetan } \\
\text { Kecamatan } \\
\text { Gegesik } \\
\text { Kabupaten } \\
\text { Cirebon }\end{array}$ \\
\hline Sanggar Tari & $\begin{array}{l}\text { Manunggal Ing } \\
\text { Darma Sastra }\end{array}$ & Nana Suryana & $\begin{array}{c}\text { Desa Kalikoa } \\
\text { Kecamatan } \\
\text { Kedawung } \\
\text { Kabupaten } \\
\text { Cirebon }\end{array}$ \\
\hline
\end{tabular}




\begin{tabular}{|c|c|c|c|}
\hline Sanggar Tari & Putri Yasmine & Sakiah N & Kelurahan \\
& & & Tukmuda \\
Kecamatan & Sumber \\
& & & Kabupaten \\
Sanggar Tari & Wulan Sari & Kadimin & Cirebon \\
Topeng & & & Desa \\
& & & Kedungbunder \\
& & & Kecamatan \\
& & & Kabupaten \\
& & & Cirebon \\
\hline Sanggar Tari & Tri Tunggal & Kudi Hadira & Kesa Tegalwangi \\
& Budaya & & Cirebon \\
\hline
\end{tabular}

(sumber: Dispudparpora.cirebonkab.go.id 2017)

Kesenian-kesenian yang ada di Kabupaten Cirebon diantaranya ada seni tari, seni musik dan wayang serta nama grup seni atau sanggar seni yang ada di Kabupaten Cirebon. Kesenian-kesenian tersebut berada diberbagai desa yang ada di Kabupaten Cirebon. Desa Plumbon menjadi salah satu desa yang memiliki sanggar seni yaitu Sanggar Seni Pringgadhing yang dipimpin oleh bapak Handoyo (alm). Selain kesenian yang dimiliki oleh Sanggar Pringgadhing, desa Plumbon juga memiliki beberapa potensi kesenian, yaitu kesenian lain berupa musik tarling, wayang dan qasidahan yang sering ditanggap oleh masyarakat di Desa Plumbon (wawancara dengan Bapak Kepala Desa Plumbon pada tanggal 19 Mei 2017) . kutipan wawancara sebagai berikut : 
"Kesenian yang ada di Desa Plumbon mungkin hanya ada di Sanggar Pringgadhing. Bidang seni tarinya yang popular atau dikenal oleh masyarakat adalah tari Topeng, Tayuban, Sintren, dan tari Ronggeng Bugis. Selain itu masyarakat lebih mengenal tari-tarian yang ada di Sanggar Pringadhing dari segi kostum dan gendingnya. Selain kesenian yang ada di Sanggar Pringgadhing biasanya yang sering ada di Desa Plumbon adalah tarling, wayang dan qasidah”.

\subsection{Sanggar Pringgadhing}

Sanggar merupakan suatu sarana atau tempat yang didirikan oleh individu atau suatu komunitas atau sekumpulan orang untuk melakukan suatu kegiatan belajar mengajar di luar pendidikan formal. Sanggar Pringgadhing yang bertempat di Desa Plumbon Kecamatan Plumbon Kabupaten Cirebon merupakan satusatunya sanggar yang ada di Desa Plumbon yang bergerak dibidang kesenian, baik itu seni tari maupun seni musik.

Sanggar Pringgadhing mulai di dirikan pada tahun 1974 dan telah terdaftar di Depdikbud dengan SK. No. 0968/102.18/J/1994, tanggal 11 Mei 1994. Berdirinya Sanggar Pringgadhing berawal dari rasa cinta dan kepedulian Handoyo (alm) terhadap kesenian daerahnya. Rasa cinta dan kepedulian tersebut yang menjadikan motivasi keinginannya yang kuat untuk mengembangkan serta melestarikan kebudayaan khususnya yang berasal dari daerah Cirebon. keinginannya yang besar dan kuat itu didukung pula oleh wawasan, kamampuan, bakat, dan keterampilannya dalam bidang seni budaya daerah setempat sejak kecil. Setelah dewasa bapak Handoyo (alm) sekolah ke perguruan tinggi yaitu di Sekolah Tinggi Seni Indonesia (STSI) Bandung dengan mengambil jurusan seni tari. 
Setelah bapak Handoyo meninggal pada tahun 2014, Sanggar Pringgadhing beralih kepemimpinan yaitu oleh anaknya bapak Windu sampai saat ini tahun 2017. Dari mulai berdirinya pada tahun 1974 hingga sekarang tahun 2017 Sanggar Pringgadhing hanya memiliki empat pengurus yang di dalamnya terdapat Ketua, Sekretaris, Bendahara, dan Pelatih.

Kegiatan yang terdapat di Sanggar Pringgadhing yaitu terdiri dari Pelatihan, penciptaan dan pementasan. Proses Penciptaan yang dilakukan Sanggar Pringgadhing terdapat dalam berbagai macam tari-tarian, selain tari Ronggeng Bugis, tedapat pula tari Rongeng Munggut, tari Panyenggrama Agung, tari Jala Sutra, tari Penyingkang, tari Sumilir Angin Kumbang, tari Jemparing, dan masih banyak lagi termasuk gendhing setiap tarinya. Pelatihan yang dilakukan Sanggar Pringgadhing berjalan rutin yaitu setiap satu minggu dua kali pada hari selasa dan hari jumat. Pelatihan itu diperuntukan kepada para siswa sekolah mulai dari TK sampai SMA. Selain jadwal latihan rutin, Sanggar Pringgadhing juga selalu mengadakan latihan diluar jadwal latihan rutin jika diadakan pementasan, baik pementasan di lingkungan sanggar maupun di luar sanggar.

Pementasan yang dilakukan Sanggar pringgadhing yaitu pada saat ulang tahun sanggar yang dilakukan hampir setiap tahun, dan acara haul bapak Handoyo (alm). Selain itu pementasan yang dilakukan di Gua Sunyaragi, namun pementasan di Gua Sunyaragi tidak pasti karena melihat banyak sanggar seni yang terdapat di Cirebon. (Wawancara bersama bapak Windu selaku ketua Sanggar Pringgadhing pada tanggal 24 Mei 2017). Berikut kutipan wawancara:

"Sanggar Pringgadhing mulai didirikan oleh Bapak Handoyo (alm) sejak tahun 1974' dan ini sudah masuk generasi kedua”. 
sampai saat ini kepengurusan masih dipegang oleh keluarga yang terdiri dari Ketua, sekretaris, dan pelatih. Mengenai murid yang ada di Sanggar Pringgadhing karena sampai saat ini masih terdapat siswa maka kalau dihitung dari jaman dulu mungkin sudah ribuan mbak, saya ambil 5 tahun kebelakang mungkin ada sekitar 360-an. Kemarin saat acara di Cirebon kita bawa 40 anggota dan data terakhir tercatat 90 siswa yang belajar di Sanggar Pringgadhing”.

Sanggar Pringgadhing sudah memasuki generasi kedua. Kepemimpinan pertama dari tahun 1970-2014 diketuai oleh bapak Handoyo (alm) dan saat ini sejak tahun 2014-2017 diketuai oleh anaknya bapak Windu. Kepengurusan sanggar masih dipegang oleh keluarga. Termasuk pelatih yang tugaskan kepada bu Ati, bu Ria, dan bu Gita. Mereka menjadi pelatih untuk siswa dari TK-SMA.

Sanggar Pringgadhing dari tahun berdirinya sampai tahun 2017 masih menerima siswa yang ingin belajar kesenian tradisional Cirebon atau mengikuti pelatihan di Sanggar Pringgadhing. Sesuai dengan data yang didapatkan di tahun 2017 ini terdapat 90 orang siswa yang belajar di Sanggar Pringgadhing. Berikut data peserta pelatihan di Sanggar Pringgadhing:

Tabel 4.2: Daftar nama siswa yang mengikuti pelatihan di Sanggar Pringgadhing.

\begin{tabular}{|c|l|c|c|}
\hline No & \multicolumn{1}{|c|}{ Nama } & Jenis Kelamin & Usia \\
\hline 1. & Abimanyu & L & 17 tahun \\
\hline 2. & Adi Sucipto & L & 17 trahun \\
\hline 3. & Afni Nur Azizah & P & 17 tahun \\
\hline 4. & Afrizal Febrian & L & 17 tahun \\
\hline 5. & Agus Pramudtya & L & 17 tahun \\
\hline 6. & Aldi Rohman & P & 17 tahun \\
\hline 7. & Ana Mashaf & $\mathrm{P}$ & 17 tahun \\
\hline 8. & Andini Putri & L & 17 tahun \\
\hline 9. & Ardi Permana & P & 17 tahun \\
\hline 10. & Askila Anjani & P & 16 tahun \\
\hline 11. & Cantika Sari & L & 16 tahun \\
\hline 12. & Cecep Saprudin & & \\
\hline & & & \\
\hline
\end{tabular}




\begin{tabular}{|c|c|c|c|}
\hline 13. & Choirul imam & $\mathrm{L}$ & 16 tahun \\
\hline 14. & Cindi Martika & $\mathrm{P}$ & 16 tahun \\
\hline 15. & Danang Abdulah & $\mathrm{L}$ & 16 tahun \\
\hline 16. & Dhani Ardiana & $\mathrm{L}$ & 16 tahun \\
\hline 17. & Diyah Setyawati & $\mathrm{P}$ & 16 tahun \\
\hline 18. & Dian Susilawati & $\mathrm{P}$ & 15 tahun \\
\hline 19. & Elis Sulastri & $\mathrm{P}$ & 15 tahun \\
\hline 20. & Ellisa Anjani & $\mathrm{P}$ & 15 tahun \\
\hline 21. & Euis Amalia sari & $\mathrm{P}$ & 15 tahun \\
\hline 22. & Feby Amalia & $\mathrm{P}$ & 15 tahun \\
\hline 23. & Firda Armila Zahra & $\mathrm{P}$ & 14 tahun \\
\hline 24. & Fitriyani Nurimamah & $\mathrm{P}$ & 14 tahun \\
\hline 25. & Futika Azzahra & $\mathrm{P}$ & 14 tahun \\
\hline 26. & Gylang Gumilang & $\mathrm{P}$ & 14 tahun \\
\hline 27. & Ira Widayani & $\mathrm{P}$ & 14 tahun \\
\hline 28. & Iwan Kurniawan & $\mathrm{L}$ & 14 tahun \\
\hline 29. & Jajang Abdullah & $\mathrm{L}$ & 14 tahun \\
\hline 30. & Komariyah & $\mathrm{P}$ & 14tahun \\
\hline 31. & Linda Kurniasari & $\mathrm{P}$ & 14 tahun \\
\hline 32. & Masruri Nur Salam & $\mathrm{L}$ & 14 tahun \\
\hline 33. & Mohammad Qomarudin & $\mathrm{L}$ & 14 tahun \\
\hline 34. & Muhammad Saefulllah & $\mathrm{L}$ & 13 tahun \\
\hline 35. & Muhammad Yusuf & $\mathrm{L}$ & 13 tahun \\
\hline 36. & Nabila Anandi & $\mathrm{P}$ & 13tahun \\
\hline 37. & Narendra Pratama & $\mathrm{L}$ & 13 tahun \\
\hline 38. & Nazmudin Khair & $\mathrm{L}$ & 13 tahun \\
\hline 39. & Olivia Shalsabila & $\mathrm{P}$ & 13 tahun \\
\hline 40. & Rafif Aqmar & $\mathrm{L}$ & 13 tahun \\
\hline 41. & Ricky Setiawan & $\mathrm{L}$ & 10 tahun \\
\hline 42. & Risma Yunikasari & $\mathrm{P}$ & 10 tahun \\
\hline 43. & Salahudin Al Ayubi & $\mathrm{L}$ & 11 tahun \\
\hline 44. & Silma Alika & $\mathrm{P}$ & 11 tahun \\
\hline 45. & Sinta Widiastuti & $\mathrm{P}$ & 10 tahun \\
\hline 46. & Wiranto & $\mathrm{L}$ & 10 tahun \\
\hline 47. & Yulianawati & $\mathrm{L}$ & 10 tahun \\
\hline 48. & Ajeng Nurmalsari & $\mathrm{P}$ & 10 tahun \\
\hline 49. & Annas Raihan & $\mathrm{L}$ & 10 tahun \\
\hline 50. & Annisa Nurul Hidayah & $\mathrm{P}$ & 11 tahun \\
\hline 51. & Aqila Fatma & $\mathrm{P}$ & 10 tahun \\
\hline 52. & Arifah Nurhasanah & $\mathrm{P}$ & 9 tahun \\
\hline 53. & Arfa Rizki & $\mathrm{L}$ & 9 tahun \\
\hline 54. & Asri Ayuningtyas & $\mathrm{P}$ & 9 tahun \\
\hline 55. & Aurellia Myisha & $\mathrm{P}$ & 9 tahun \\
\hline 56. & Ayu Istikomah & $\mathrm{P}$ & 9 tahun \\
\hline
\end{tabular}




\begin{tabular}{|c|c|c|c|}
\hline 57. & Azizah Ramadhani Imran & $\mathrm{P}$ & 9 tahun \\
\hline 58. & Bagas Ivan & $\mathrm{L}$ & 9 tahun \\
\hline 59. & Bayu Dwi Prasetyo & $\mathrm{L}$ & 9 tahun \\
\hline 60. & Chandra Kirana & $\mathrm{L}$ & 9 tahun \\
\hline 61. & Dian Susilawati & $\mathrm{P}$ & 9 tahun \\
\hline 62. & Dimas Budiman & $\mathrm{L}$ & 8 tahun \\
\hline 63. & Fauziyah Dwi Septiani & $\mathrm{P}$ & 8 tahun \\
\hline 64. & Febrianti Khairunnisa & $\mathrm{P}$ & 8 tahun \\
\hline 65. & Fiky Triansyah & $\mathrm{L}$ & 8 tahun \\
\hline 66. & Hesti Anjani & $\mathrm{P}$ & 8 tahun \\
\hline 67. & Hilda Meilareza & $\mathrm{L}$ & 8 tahun \\
\hline 68. & Indah Purnamasari & $\mathrm{P}$ & 8 tahun \\
\hline 69. & Kharisma sari & $\mathrm{P}$ & 8 tahun \\
\hline 70. & Kiki Hastunisa & $\mathrm{P}$ & 7 tahun \\
\hline 71. & Meliana Putri Charissida & $\mathrm{P}$ & 7 tahun \\
\hline 72. & Mufida Aini & $\mathrm{P}$ & 7 tahun \\
\hline 73. & Muhammad Rizki Setiawan & $\mathrm{L}$ & 7 tahun \\
\hline 74. & Muhammad Wahid & $\mathrm{L}$ & 7 tahun \\
\hline 75. & Muhammad Yuditama & $\mathrm{L}$ & 7 tahun \\
\hline 76. & Nana Suryana & $\mathrm{L}$ & 6 tahun \\
\hline 77. & Nur Azizah & $\mathrm{P}$ & 6 tahun \\
\hline 78. & Nurul Hidayah & $\mathrm{P}$ & 6 tahun \\
\hline 79. & Ragil Ayu & $\mathrm{P}$ & 6 tahun \\
\hline 80. & Ratna Fila Rahayu & $\mathrm{P}$ & 6 tahun \\
\hline 81. & Riko Prasetya & $\mathrm{L}$ & 6 tahun \\
\hline 82. & Riska Dianti & $\mathrm{P}$ & 5 tahun \\
\hline 83. & Riski Anrdeanto & $\mathrm{P}$ & 5 tahun \\
\hline 84. & Salsyabila Jannah & $\mathrm{P}$ & 5 tahun \\
\hline 85. & Siti Zulfa & $\mathrm{P}$ & 5 tahun \\
\hline 86. & Uswatun Khasanah & $\mathrm{P}$ & 6 tahun \\
\hline 87. & Vian Adam Setyo & $\mathrm{P}$ & 6 tahun \\
\hline 88. & Vivi Kusumastuti & $\mathrm{L}$ & 5 tahun \\
\hline 89. & Widia Anggraeni & $\mathrm{P}$ & 5 tahun \\
\hline 90. & Yulia Puji Astuti & $\mathrm{P}$ & 5 tahun \\
\hline
\end{tabular}

Sumber : (observasi penelitian, data administrasi

Sanggar Pringgadhing Mei 2017)

Bergantinya generasi juga dapat mempengaruhi cara kepemimpinan. Salah satu pengaruh yang ada di kepemimpinan bapak Windu saat ini Sudah terlihat perkembangannya. Perkembangan yang terjadi yaitu dalam bidang seni musiknya, dahulu saat masih dipimpin oleh bapak Handoyo (alm) tidak terdapat musik- 
musik modern, namun sekarang saat kepemimpinan dipegang oleh bapak Windu terdapat studio musik yang bukan hanya ada alat-alat musik tradisionalnya saja namun juga terdapat alat musik modern di dalamnya.

Sedangkan dalam bidang seni tarinya, belum terdapat perubahan. Semua tari-tarian yang ada di Sanggar Pringgadhing masih merupakan tari-tarian yang diciptakan oleh alm.pak Handoyo. (observasi sanggar pada tanggal 19 Mei 2017). Sanggar pringgadhing setiap tahunnya melakukan acara haul dalam rangka mengenang jasa-jasa bapak Handoyo (alm) yang telah menyumbangkan rasa cintanya terhadap seni tradisi Cirebon dan ikut melestarikan kesenian-kesenian tradisional di Kabupaten Cirebon.

\subsection{Sejarah Tari Ronggeng Bugis di Sanggar Pringgadhing}

Tari Ronggeng Bugis berasal dari kata Ronggeng yang berarti Penari Wanita dan Bugis ialah suku yang ada di daerah Sulawesi Selatan. Sejarah awal Tari Ronggeng Bugis Cirebon merupakan bentuk pengalaman kolektif di masa lampau yang menceritakan suatu kejadian yang diungkapkan kembali melalui gerak tari. Lebih tepatnya Tari Ronggeng Bugis muncul pada saat Cirebon berada dibawah pemerintahan Syekh Maulana Syarif Hidayatullah atau lebih dikenal dengan nama Sunan Gunung Jati (1482 M), yang ingin menjadikan Cirebon sebagai pusat kerajaan dan menyatakan diri sebagai kerajaan Islam yang berdaulat penuh dan lepas dari segala ikatan Pakuan Padjadjaran. Segala macam kewajiban, seperti bayar upeti atau pajak dan semacamnya, semuanya dihentikan. Menyadari akan posisinya sebagai daerah kekuasaan Pakuan Padjajaran, maka Cirebon segera mempersiapkan diri untuk menghadapi segala kemungkinan yang akan 
terjadi sebagai konsekuensi logis atas pernyataannya memproklamirkan diri sebagai negara merdeka. Akhirnya setelah melalui proses perundingan yang cukup lama, pejabat keraton yang telah terbentuk saat itu, memutuskan untuk mengetahui reaksi Pakuan Padjadjaran terhadap tindakan Cirebon yang melepaskan diri dari daerah otoritas pemerintahannya dengan cara mengirim telik sandi.

Paparan di atas berkaitan dengan sebuah wawancara bersama penari tari Ronggeng Bugis bapak Heri. Berikut kutipan wawancaranya:

"Tari Ronggeng Bugis dalam sejarahnya yang telah saya ketahui dan oleh banyak orang, yaitu tarian yang awalnya adalah utusan dari Sunan Gunung Jati untuk memata-matai atau menjadi telik sandi di kerajaan Padjajaran. Yang menjadi telik sandi tersebut adalah orang keturunan Bugis yang sudah tinggal lama di kerajaan Cirebon dan memilki keberanian untuk menyamar sampai pada akhirnya pasukan telik sandi berhasil dalam misi yang diperintahkan Sunan Gunung Jati sehingga telik sandi mendapat penghargaan dari Sunan Gunung Jati sebagai sebuah tari tradisi Cirebon dan diberi nama Tari Ronggeng Bugis".

Untuk menentukan siapa dan bagaimana telik sandi itu mesti dilakukan, tentu mendapat kesulitan. Sebab dibutuhkan seorang pemberani, bermental kuat cerdas, serta pandai menyamar. Keluarlah nama Sahdan seorang pemuda keturunan Bugis, akhirnya Sahdan dengan beberapa temannya sanggup melaksanakan tugas penyamaran tersebut. Diceritakan bahwa pemuda keturunan Bugis tersebut telah menetap di Cirebon sejak sebelum Cirebon dipimpin oleh Sunan Gunung Jati. Akhirnya dengan hasil musyawarah terdapat kesepakatan dalam suatu pasewakan agung diputuskan serta disetujui bahwa pengemban tugas telik sandi dipercayakan kepada para pemuda keturunan Bugis. 
Upaya penyamaran mereka menciptakan semacam tarian dengan dandanan yang dibuat dengan menirukan dandanan wanita, mulai dari tata rias dan busananya. Atas kesepakatan mereka bersama, pertunjukan tari yang diciptakan dilakukan dengan cara helaran dan menyamar sebagai pengamen. Selanjutnya sepanjang perjalanan melalui seluruh wilayah kekuasaan Padjadjaran, mereka bergerak menari sambil membunyikan tetabuhan (musik). Berkat cara seperti itu ternyata berhasil menyedot perhatian masyarakat di sepanjang jalan yang dilaluinya, rombongan pengamen samaran itu sama sekali tidak dicurigai sedikit pun oleh masyarakat maupun oleh pejabat Pakuan Padjadjaran. Bahkan saking menariknya tarian yang mereka bawakan, rombongan telik sandi tersebut bisa dengan leluasa masuk ke keraton Padjadjaran atas permintaan Raja. Dengan demikian telik sandi berhasil mendapatkan informasi yang diinginkan oleh Sunan Gunung Jati. Atas jasa-jasa pemuda keturunan Bugis tersebut, Sunan Gunung Jati merestui untuk memajukan kesenian yang mereka ciptakan itu sebagai salah satu seni keraton, dan selanjutnya kesenian ini dikenal dengan nama Ronggeng Bugis.

Selain sejarah tari Ronggeng Bugis secara umum dikalangan masyarakat Cirebon Barat seperti yang diceritakan diatas, berikut adalah perkembangan sejarah tari Ronggeng Bugis di Sanggar Pringgadhing Plumbon Cirebon dimulai dari dedikasi bapak Handoyo (alm) yang saat itu sebagai seorang koreografer Kacirebonan sekaligus pendiri Sanggar Pringgadhing, beliau awalnya mengajarkan tari Ronggeng Bugis di Keraton Kacirebonan kemudian berkat adanya dukungan dari Petinggi Keraton maka Ronggeng Bugis mulai dikenal oleh masyarakat dan keluar dari tembok keraton. Dan mulai diajarkan di Sanggar 
Pringgadhing oleh bapak Handoyo untuk menjadi seni pertunjukan yang menarik dan diminati oleh masyarakat. Sejak saat itulah masyarakat luas mengenal tari Ronggeng Bugis pertama kali dari Sanggar Pringgadhing. Alasan bapak Handoyo (alm) mengangkat tari Ronggeng Bugis menjadi seni pertunjukan yang dapat dinikmati oleh masyarakat luas ialah karena beliau menganggap bahwa tari Ronggeng Bugis merupakan bagian dari Sejarah Cirebon, selain itu tariannya juga unik, dan lucu sehingga dapat membuat penonton tertarik untuk menonton atau bahkan mempelajari tari Ronggeng Bugis.

Tari Ronggeng Bugis mulai dikenal oleh masyarakat Cirebon pada tahun 1994 dan berkembang di Sanggar Pringgadhing sampai saat ini tahun 2017 karena peran serta bapak Handoyo dan kawan-kawannya. Selain itu para penari tari Ronggeng Bugis di Sanggar Pringgadhing sampai saat ini masih sama yaitu penarinya laki-laki dewasa umur 25-40 tahun dikarenakan ingin tetap menonjolkan keistimewaan tari Ronggeng Bugis yang ada di Sanggar Pringgadhing. Hal ini juga yang menjadi daya tarik masyarakat bahkan dinas kebudayaan dan pariwisata untuk bekerjasama dengan Sanggar Pringgadhing dan ikut melestarikan tari tradisi yang ada di Cirebon kususnya tari Ronggeng Bugis.

Tari Ronggeng Bugis awalnya adalah kesenian yang ada di daerah Cangkring, pelaku seninya bernama bapak Tiswo. Saat itu tahun 1994 akan diadakan Festival Kesenian Jawa-Madura, untuk persiapan acara tersebut akhirnya diangkat oleh tiga pelaku seni yaitu, pak Tiswo, Budayawan Cirebon Pak Kartani, dan yang seniman bapak Handoyo (alm). Awalnya tari Ronggeng Bugis hanya memiliki tiga gerakan, karena kebutuhan acara akhirnya ketiga pelaku seni 
bekerjasama menggarap tari Ronggeng Bugis dan dihasilkanlah 17 ragam gerak yang sampai saat ini digunakan oleh Sanggar Pringgadhing.

Paparan di atas dikaitkan dalam sebuah wawancara tentang sejarah tari Ronggeng Bugis yang dituturkan oleh Bapak Windu Berikut kutipan wawancara:

"Sejarah tari Ronggeng Bugis ini adalah tarian mata-mata yang disuruh atau diperintahkan oleh Sunan Gunung Jati pada masa kepemimpinannya untuk memata-matai kerajaan Galuh Pajajaran.

yang melatarbelakangi bapak Handoyo(alm) untuk mengangkat tari Ronggeng Bugis menjadi tari pertunjukan yaitu saat akan diadakan Festival Kesenian Jawa-Madura bapak berinisiatif mengangkat tari ini menjadi sebuah tari pertunjukan, sebelumnya tari Ronggeng Bugis hanya memiliki tiga gerak saja, namun karena ini difestivalkan maka bapak dan kedua rekannya menggarap tari Ronggeng Bugis menjadi 17 ragam gerak yang sampai saat ini digunakan".

(wawancara dengan Bapak Windu Ketua Sanggar Pringgadhing pada 19 Mei 2017).

\subsection{Eksistensi Tari Ronggeng Bugis}

Tari Ronggeng Bugis sebelumnya kurang dikenal oleh masyarakat. Pada awal tahun 1990 setelah tari Ronggeng Bugis diajarkan di Keraton Kacirebonan oleh Bapak Handoyo (alm) dengan dukungan Pangeran Yusuf Dendabrata, maka Ronggeng Bugis mulai lebih dikenal oleh masyarakat luas yaitu di luar Keraton Kacirebonan. Tari Ronggeng Bugis yang telah dikembangkan oleh alm. bapak Handoyo pertama kali dipentaskan pada acara Festival Keraton Nusantara 1994, selanjutnya tari Ronggeng Bugis selalu diikutsertakan dalam acara Festival Nusantara tersebut yang dimulai pada tahun 1994 di Yogyakarta.

Menurut penuturan dari bapak Dayat dan bapak Wili yang merupakan penari dari Tari Ronggeng Bugis di Sanggar Pringgadhing, Tari Ronggeng Bugis dibawakan oleh duta budaya Pramuka Sekolah Tinggi Agama Islam Negeri (STAIN) Cirebon ke berbagai daerah seperti pada tanggal 22-23 september 2002 
di Lampung Selatan, 23-31 Agustus 2005 di Kepulauan Seribu, tahun 2008 ke Palembang. Keikutsertaan tari Ronggeng Bugis tersebut tidak terlepas dari peran pelatih dan para penari Ronggeng Bugis di Sanggar Pringgadhing yang mengajarkan tari Ronggeng Bugis kepada mahasiwa di STAIN Cirebon.

Kemudian Juni 2009 tari Ronggeng Bugis Sanggar Pringgadhing dipertunjukan pada festival di Jambi. Kemudian dalam acara Car Free Day Siliwangi Kota Cirebon 2014, Pembukaan Hotel Batiqa Cirebon 2015, pergelaran seni budaya tradisional di Taman Budaya Bandung Jawa Barat 2015 dan 2016, Festival Pesona Cirebon Maret 2016, Haul Bapak Handoyo Agustus 2016, Anjungan Jawa Barat di Taman Mini Indonesia Indah (TMII) 2016, April 2017 turut berpartisipasi dalam Hari Jadi ke-246 Kabupaten Gianyar Bali, dan terakhir ini tari Ronggeng Bugis Sanggar Pringgadhing juga ikut serta dalam mengisi acara dalam rangka Pemilihan Jaka Rara Kota Cirebon pada 21 Mei 2017.

Eksistensi tari Ronggeng Bugis di Sanggar Pringgadhing telah ditunjukan dengan adanya pementasan-pementasan yang dilakukan sampai tahun 2017. Ini membuktikan bahwa tari Ronggeng Bugis di Sanggar Pringgadhing masih eksis dan telah diakui oleh masyarakat, serta adanya kerjasama antara pelaku seni di Sanggar Pringgadhing dengan Dinas Kebudayaan setempat. Seperti yang dituturkan oleh bapak Hartono selaku ketua Dinas Kebudayaan, Pariwisata, Pemuda dan Olahraga (DISBUDPARPORA) Kabupaten Cirebon mengatakan jika tari Ronggeng Bugis merupakan bagian dari kesenian tradisional yang ada di Kabupaten Cirebon yang harus dilestarikan dan dijaga keberadaannya. 
Untuk menjaga eksitensi Tari Ronggeng Bugis, Sanggar Pringgadhing melakukan pelatihan baik pelatihan di dalam sanggar maupun di luar sanggar seperti di sekolah-sekolah. Sanggar Pringgadhing melalui peran pelatih dan para penarinya mengajarkan tari Ronggeng Bugis kepada anak-anak sekolah mulai dari siswa Taman Kanak-kanak (TK) sampai siswa Sekolah Menengah Atas (SMA) yang diajarkan oleh bu ati selaku pelatih tari di Sanggar Pringgadhing kepada para siswa yang belajar menari di Sanggar Pringgadhing.

Pelatihan di luar sanggar dilakukan oleh para penari Ronggeng Bugis yang mengajarkan tari Ronggeng Bugis melalui eskul tari yang ada di sekolah, diantaranya adalah SMKN 1 Kedawung, SMAN 1 Sumber, dan SMKN 1 Mundu. Para siswa diajarkan tari Ronggeng Bugis karena tari Ronggeng Bugis menjadi salah satu materi praktik yang diujikan di sekolah.

Seperti yang dipaparkan oleh kelapa sekolah SMK N 1 Kedawung bapak H. Fuad, S.Pd., M.Pd, beliau mengatakan bahwa tari Ronggeng Bugis diminati oleh para siswa karena tariannya yang lucu, sehingga dapat menghibur setiap penonton yang melihatnya. Meskipun tari Ronggeng Bugis adalah tarian yang ditarikan oleh laki-laki dengan gerakan perempuan, namun siswa-siswa tidak merasa terbebani karena takut dibilang banci. Sehingga sekolahpun berani untuk menjadikan tari Ronggeng Bugis sebagai materi untuk ujian praktik.

Proses sampai Tari Ronggeng Bugis diajarkan di sekolah sebagai materi praktik adalah karena mayoritas guru-guru keseniannya mengetahui Tari Ronggeng Bugis saat ada pentas tari Ronggeng Bugis di Sunyaragi, sehingga mereka sepakat untuk menjadikan tari Ronggeng Bugis sebagai bahan ujian 
praktik. Meskipun tari Ronggeng Bugis terlihat mudah namun sebenarnya butuh mental yang kuat untuk menarikan tari Ronggeng Bugis, karena tari Ronggeng Bugis ditarikan oleh laki-laki namun gerakan yang terdapat dalam Tari Ronggeng Bugis tidak menunjukan gerak laki-laki yang kuat, bervolume besar dan terlihat gagah, namun tari Ronggeng Bugis memiliki gerakan perempuan yang lemah gemulai namun lucu.

Selain pemaparan dari kepala sekolah mengenai tari Rongeng Bugis, ada juga pengakuan dari siswa SMKN 1 Kedawung yang ikut menjadi penari tari Ronggeng Bugis, taufik menceritakan pengalamannya telah menarikan tari Ronggeng Bugis dengan penampilan dan kostum yang begitu konyol namun fenomenal, tari Ronggeng Bugis yang mereka persembahkan untuk para penonton mendapatkan respon yang cukup baik. Semua penonton tertawa terbahak-bahak ketika mereka menari. Ternyata dengan adanya pengajaran tari Ronggeng Bugis untuk para siswa sekolah, maka tari Ronggeng Bugis semakin eksis dan dikenal. Selain itu tari Ronggeng Bugis juga membuat para siswa lebih kreatif dan percaya diri. Karena saat tari Ronggeng Bugis dibawakan oleh anak-anak yang tidak memiliki besik menari maka yang akan muncul adalah kekonyolan-kekonyolan gerak mereka yang akan membuat penonton tertawa dan terhibur.

Tari Ronggeng Bugis yang dipentaskan di sekolah biasanya menggunakan halaman sekolah sebagai panggung pertunjukan atau yang disebut Helaran. Dalam setiap pementasan helaran tari Ronggeng Bugis memiliki berapa aspek yang dipenuhi, dengan harapan mampu dinikmati oleh masyarakat dan penikmat 
seni. Seperti tari Ronggeng lain, tari Ronggeng Bugis di Sanggar Pringadhing dibuat tarian kelompok yaitu dengan penari lebih dari tiga orang.

Perbedaan tari Ronggeng Bugis di Sanggar Pringgadhing dengan sanggar lain terlihat hampir dari setiap aspek dalam tari mulai dari gerak, iringan, hingga kostum. Kini tari Ronggeng Bugis milik Sanggar Pringgadhing telah berkembang dan dikenal di masyarakat. Bukan hanya oleh masyarakat Kabupaten/Kota Cirebon. tari Ronggeng Bugis juga telah di kenal di Jawa Barat.

\subsection{Upaya-Upaya Mempertahankan Eksitensi Tari Ronggeng Bugis}

\subsubsection{Perkembangan Tari Ronggeng Bugis}

Perkembangan tari Ronggeng Bugis yang ada di Sanggar Pringgadhing yaitu sudah terciptanya tari kreasi baru Tari Ronggeng Telik yang terinpirasi dari tari Ronggeng Bugis. Tari Ronggeng Telik merupakan perkembangan dari tari Ronggeng Bugis yang diciptakan oleh Sanggar Pringgadhing. Perbedaan yang terdapat dari tari Ronggeng Bugis dan tari Ronggeng telik terlihat dari mulai gerak, kostum, penari, hingga musik pengiringnya. Gerak tari Ronggeng Telik banyak mengadopsi dari gerak-gerak tari Ronggeng Bugis. Dan penari dalam dari Ronggeng Telik tidak harus laki-laki yang menarikannya. Tetapi penari laki-laki dan perempuan. Namun tarian ini bukan tari berpasangan.

Terdapat pula perkembangan pada perubahan fungsi dari tari Ronggeng Bugis yaitu sebagai hiburan dan sarana pendidikan. Fungsi tari Ronggeng di Sanggar Pringadhing saat ini selain sebagai hiburan yaitu tariannya hanya dapat dinikmati sebagai hiburan yang menghibur dengan bobot tarian yang ringan 
namun masih tedapat nilai-nilai keindahan didalamnya, dan fungsi tari Ronggeng Bugis sudah menjadi sarana pendidikan maksudnya yaitu tari Ronggeng Bugis sudah dijadikan alat untuk pendidikan dengan menggunakan nilai-nilai yang ada pada tarian untuk tujuan pendidikan, contoh nilai-nilai pendidikan yang ada pada tari Ronggeng Bugis untuk siswa ialah akan lebih melatih rasa percaya diri, mengasah kreativitas dan belajar menjadi seorang mata-mata yang cerdas. Selain itu karena masyarakat masih ingin mempertahankan tari Ronggeng Bugis sebagai kesenian Cirebon dan masyarakat juga merasa senang dan terhibur saat melihat tari Ronggeng Bugis.

Setelah itu perkembangan yang terjadi pada tari Ronggeng Bugis adalah dalam panggung pementasannya. Sanggar Pringgadhing menjadi sanggar pertama yang mengangkat tari Ronggeng Bugis menjadi sebuah tari pertunjukan. Pada saat Cirebon sudah mempunyai tempat untuk pementasan kesenian-kesenian daerah di panggung pertunjukan yang ada di dalam tempat wisata Gua Sunyaragi, sehingga masyarakat menjadi lebih mudah untuk melihat kesenian-kesenian tradisi Cirebon yang bisa dijadikan hiburan. Selain menjadi hiburan, berkat adanya panggung pertunjukan seni di Gua Sunyaragi juga menjadi bahan edukasi atau pendidikan bagi para guru seni budaya di Cirebon khususnya dan umumnya di Jawa Barat untuk mendapat tambahan referensi kesenian untuk bahan ajar.

Keistimewaan tari Ronggeng Bugis yang ada di Sanggar Pringgadhing dapat dilihat dari segi pengajarannya dan bentuk pertunjukannya. Dari segi pengajarannya tari Ronggeng Bugis di sanggar Pringgadhing selain diajarkan disanggar juga melalui para penarinya mengajarkan di ekstra kurikuler dibeberapa 
sekolah sehingga berkembang dan dikenal oleh anak-anak sekolah. Sedang dari segi penampilan atau pementasaanya tari Ronggeng Bugis di Sanggar Pringgadhing selalu memiliki strategi sendiri untuk menarik perhatian peonton yang menyaksikan penampilanya. Tari Ronggeng Bugis selalu ditampilkan dibagian penutup acara, ini bertujuan untuk mengantisipasi penonton supaya tetap menyaksikan acara sampai selesai. Karena tari Ronggeng Bugis merupakan tarian yang biasanya dinanti-nanti oleh penonton. Dan dari segi kostum, tari Ronggeng Bugis di Sanggar Pringgadhing memiliki beberapa kostum yang bertujuan untuk membuat tari Ronggeng Bugis Sanggar Pringgadhing berbeda dengan tari Ronggeng Bugis milik sanggar lain. Yang pada akhirnya dapat menarik minat para pelajar tari Ronggeng Bugis di Sanggar Pringgadhing.

\subsubsection{Faktor-Faktor Yang Dipertahankan}

\subsubsection{Pelaku}

Berdasarakan jumlah penarinya dalam kajian koregrafi, tari Ronggeng Bugis termasuk dalam tari kelompok. Mengapa tari kelompok, karena tari ini dilakukan oleh lebih dari 3 orang.

Pada awal kemunculan Tari Ronggeng Bugis biasa ditarikan oleh enam hingga 12 orang yang terdiri dari satu wanita yang dijadikan komandan pada saat itu dan selebihnya prajurit laki-laki maka penentunya hanya karena tarian kelompok dan penarinya mayoritas laki-laki namun dengan perkembangan zaman, Tari Ronggeng Bugis saat ini sudah bisa ditarikan tidak hanya laki-laki dewasa, melainkan perempuan dewasa dan remaja putra-putri. Jadi disini gender berpengaruh pada Tari Ronggeng Bugis. Namun sampai saat ini setiap kali ada 
pementasan di luar sanggar seperti undangan atau permintaan dari dinas, maka Sanggar Pringgadhing membawa penari laki-laki untuk menarikan tari Ronggeng Bugis (wawancara dengan Bapak Wndu pada tanggal 21 Mei 2017). Kutipan wawancara sebagai berikut:

"Dalam tari Ronggeng Bugis jumlah penari aslinya adalah sekitar 9-12 orang, namun jumlah ini tidak paten dalam setiap pertunjukannya. Jadi jumlah penari tari Ronggeng Bugis menyesuaikan acara atau permintaan dari pengundang. Sanggar Pringgadhing lebih menekankan pada setiap acaranya terutama undangan untuk acara-acara besar Kabupaten Cirebon, atau permintan dari Dinas Kebudayaan yaitu para penarinya laki-laki dewasa, sedangkan dalam jumlahnya itu tidak menentu. Perbedaanya mungkin dalam komposisi tarinya jika penari lebih sedikit jadi lebih sederhana, namun jika jumlah penari banyak maka akan lebih berfariasi lagi komposisinya."

Tari Ronggeng Bugis merupakan tarian yang ditarikan oleh laki-laki yang menirukan gerak perempuan. Jumlah penari tidak menentu tergantung situasi dan kondisi acara serta tempat pertunjukan. Misalnya dalam acara kirab budaya Cirebon, dan Car Free Day, tari Ronggeng Bugis disajikan dalam bentuk helaran dan jumlah penari bisa 6-15 orang dengan jalan raya sebagai tempat pertunjukannya dan tidak ada batas antara penari dan penonton. Kemudian jika dalam pertunjukan diatas panggung tari Ronggeng Bugis bisa menampilkan penari dalam bentuk kelompok kecil maupun besar yaitu 3-15 orang. Kelompok kecil sekitar tiga sampai enam orang jika dipanggung tertutup dan jika ditampilkan di panggung terbuka yang lebih lebar seperti panggung yang ada di Gua Sunyaragi bisa mencapai 15 orang. menurut jumlah penari tari Ronggeng Bugis memang tidak menentu, namun lebih baik ditarikan kelompok besar karena pola lantai akan lebih terlihat dinamis dan bervariasi. 
Saat pertunjukan tari Ronggeng Bugis biasa mengajak penonton untuk ikut serta menari dalam salah satu gerakan didalam Tari Ronggeng Bugis dan itu salah satu yang membuat penonton selau menanti-nanti Tari Ronggeng Bugis dalam setiap pertunjukanya. Selain itu dalam setiap pertunjukan Tari Ronggeng Bugis terdapat satu kapten atau komandan untuk mengawali tarian. Untuk menjadi seorang komandan harus memiliki kelebihan yaitu kelebihan dalam membuat orang tertawa dengan tingkahnya yang lucu dan konyol namun tetap terlihat natural atau tidak dibuat-buat.

\subsubsection{Gerak}

Tari Ronggeng bugis termasuk dalam tari yang jika dilihat dari segi pola garapnya yaitu sebagai tari trdisi kerakyatan, hal ini dapat dilihat dari bagaimana bapak Handoyo (alm) menciptakan gerak-gerak yang sederhana, pola lantai yang biasa digunakan oleh tari-tari tradisi kerakyatan yaitu pola garis lengkung dan garis lurus.

Meskipun Tari Rongeng Bugis sudah memiliki gerak paten, selain itu juga menitikberatkan pada keterampilan dan eksplorasi gerak penarinya. Untuk menarikan Tari Ronggeng Bugis, tidak hanya bisa dalam teknis menari, tetapi lebih ditekankan juga untuk mampu membawa emosi penonton agar ikut serta dalam menikmati tarian lewat ekspresi dramatik para penari.

Pola gerak yang digunakan oleh penari Ronggeng Bugis adalah gerak tari tradisi kreasi dan bukan gerakan seperti pada tari klasik. Meskipun tari Ronggeng Bugis ditarikan oleh penari laki-laki, namun gerak yang digunakan bukan gerakan yang gagah, kuat dan bervolume. Namun gerak dalam tari Ronggeng Bugis lebih 
menitik beratkan pada pola-pola gerak dengan mengandalkan kelenturan gestur tubuh dan dibuat gerak-gerak spontanitas untuk menambah kesan humor didalamnya, termasuk di dalamnya mengolah ekspresi wajah yang menghasilkan mimik lucu.

Gerak-gerak yang ada dalam tari Ronggeng Bugis lebih banyak menggunakan gerak-gerak maknawi yang menyimbolkan gerak-gerak sebagai seorang mata-mata.

Tabel 4.5.2.2: Deskripsi ragam gerak tari Ronggeng Bugis

\begin{tabular}{|c|c|c|c|}
\hline No & $\begin{array}{c}\text { Nama Ragam } \\
\text { Gerak }\end{array}$ & Gambar & Deskripsi gerak \\
\hline 1. & $\begin{array}{l}\text { Incek } \\
\text { panimbal }\end{array}$ & & $\begin{array}{l}\text { Incek panimbal } \\
\text { merupakan nama ragam } \\
\text { gerak pertama dalam } \\
\text { Tari Ronggeng Bugis. } \\
\text { Ragam ini dilakukan } \\
\text { dengan kaki berjalan } \\
\text { memutar dan tangan } \\
\text { kanan memegang sampur } \\
\text { yang dilebarkan } \\
\text { kesamping. Tangan kiri } \\
\text { miwir sampur dan } \\
\text { diletakan tepat di } \\
\text { samping pinggul. }\end{array}$ \\
\hline
\end{tabular}




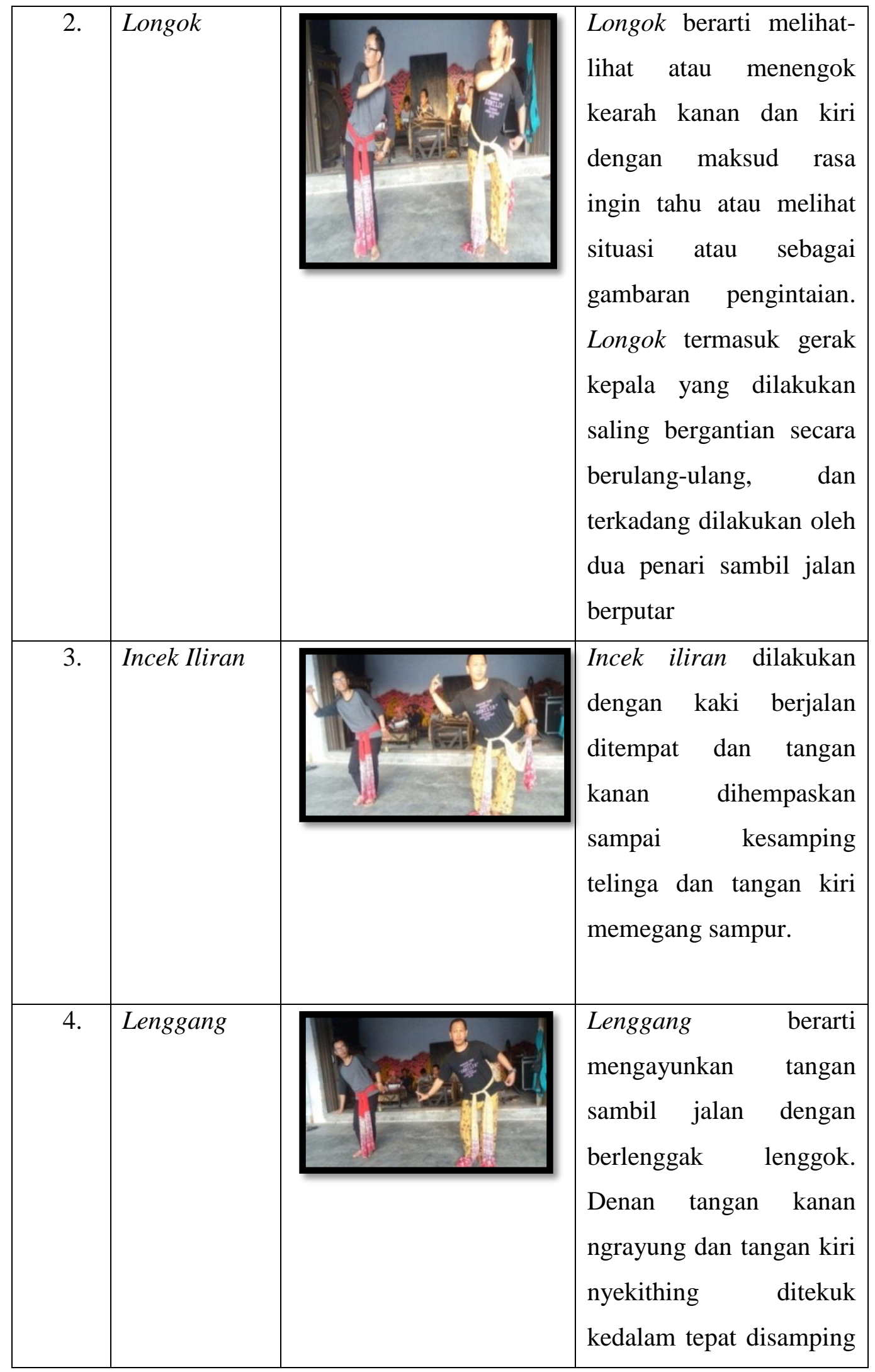




\begin{tabular}{|c|c|c|}
\hline & & pinggul \\
\hline 5. & Injen & $\begin{array}{l}\text { Injen berarti mengintip } \\
\text { atau melakukan } \\
\text { pengintaian. Dengan } \\
\text { kaki yang dibuka lebar } \\
\text { kaki depan kedepan dan } \\
\text { kaki kiri kebelakang. } \\
\text { Kedua tangan miwir } \\
\text { sampur dan dan } \\
\text { diletakkan di samping } \\
\text { dengan kedua tangan } \\
\text { dibuka dan pandangan } \\
\text { menoleh ke arah kiri dan } \\
\text { kanan. }\end{array}$ \\
\hline 6. & Uiliran & $\begin{array}{l}\text { Uliran dilakukan dengan } \\
\text { tangan kanan diputar } \\
\text { disamping pelipis kanan } \\
\text { dan tangan kiri } \\
\text { menopang tangan kanan, } \\
\text { gerak ini dilakukan } \\
\text { sambil berjalan atau } \\
\text { hanya ditempat. Gerak } \\
\text { uliran ini disibolkan } \\
\text { sebagai gerak untuk } \\
\text { berpikir melakukan } \\
\text { sesuatu atau mencari ide. }\end{array}$ \\
\hline
\end{tabular}




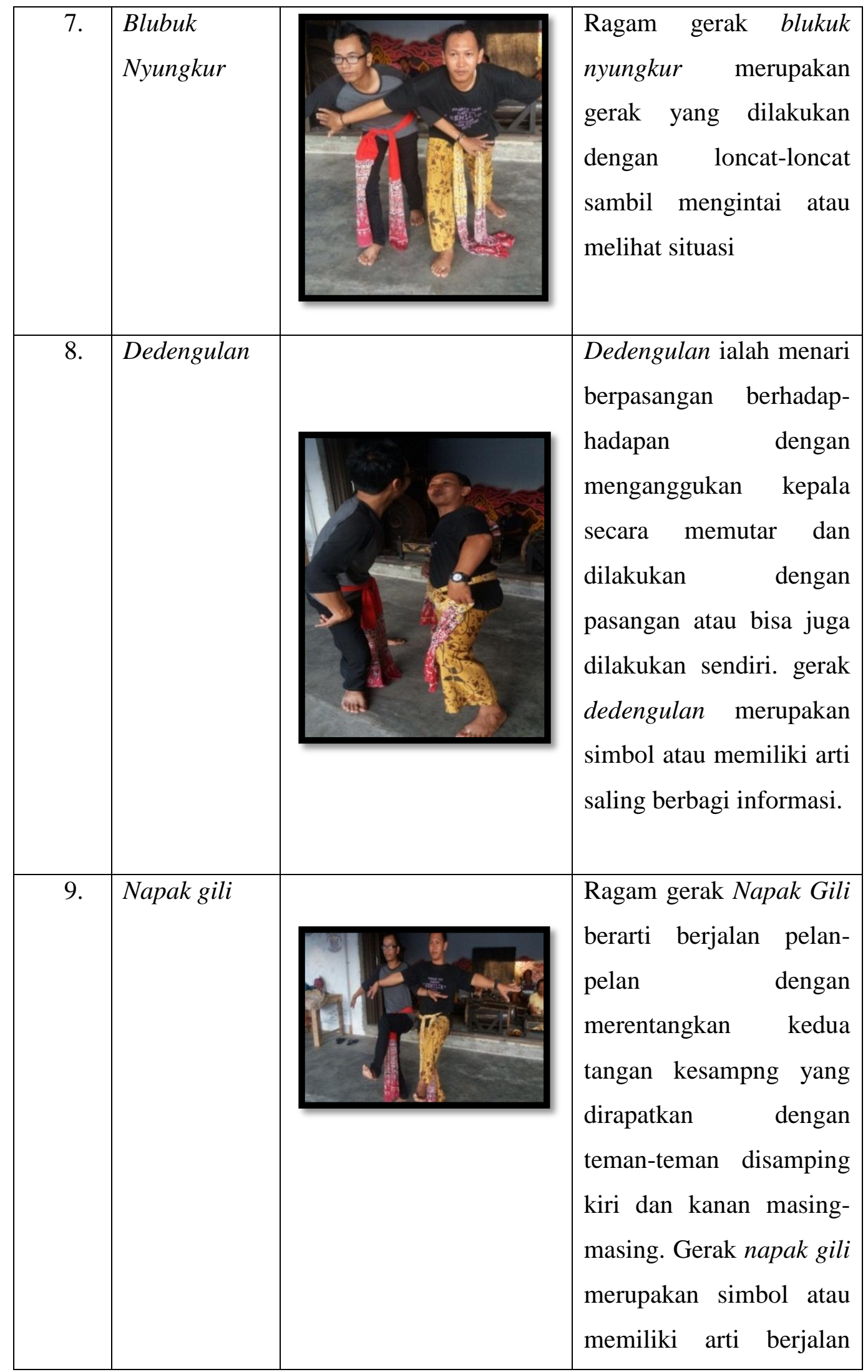




\begin{tabular}{|c|c|c|}
\hline & & $\begin{array}{l}\text { perlahan untuk mengintai } \\
\text { musuh. }\end{array}$ \\
\hline 10. & Grubugan & 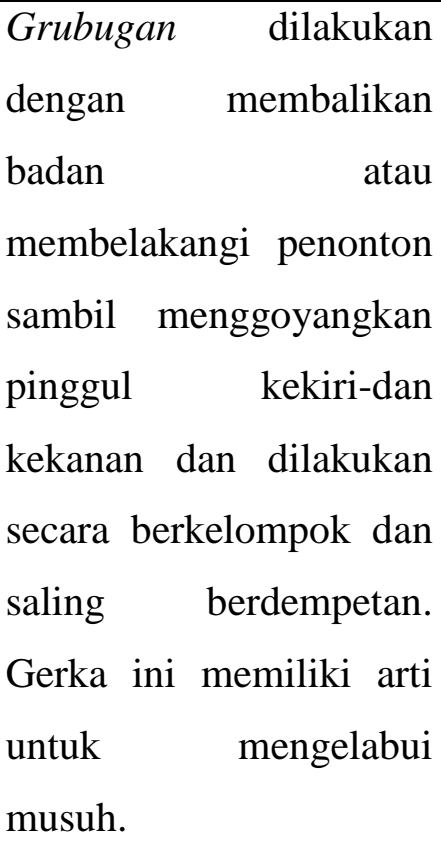 \\
\hline 11. & $\begin{array}{l}\text { Incek Blarak } \\
\text { Sengke }\end{array}$ & $\begin{array}{l}\text { Incek Blarak Sengke } \\
\text { ditarikan dengan berjalan } \\
\text { memutar dan kedua } \\
\text { tangan nyekithing } \\
\text { menjepit sampur kearah } \\
\text { samping kiri. }\end{array}$ \\
\hline
\end{tabular}




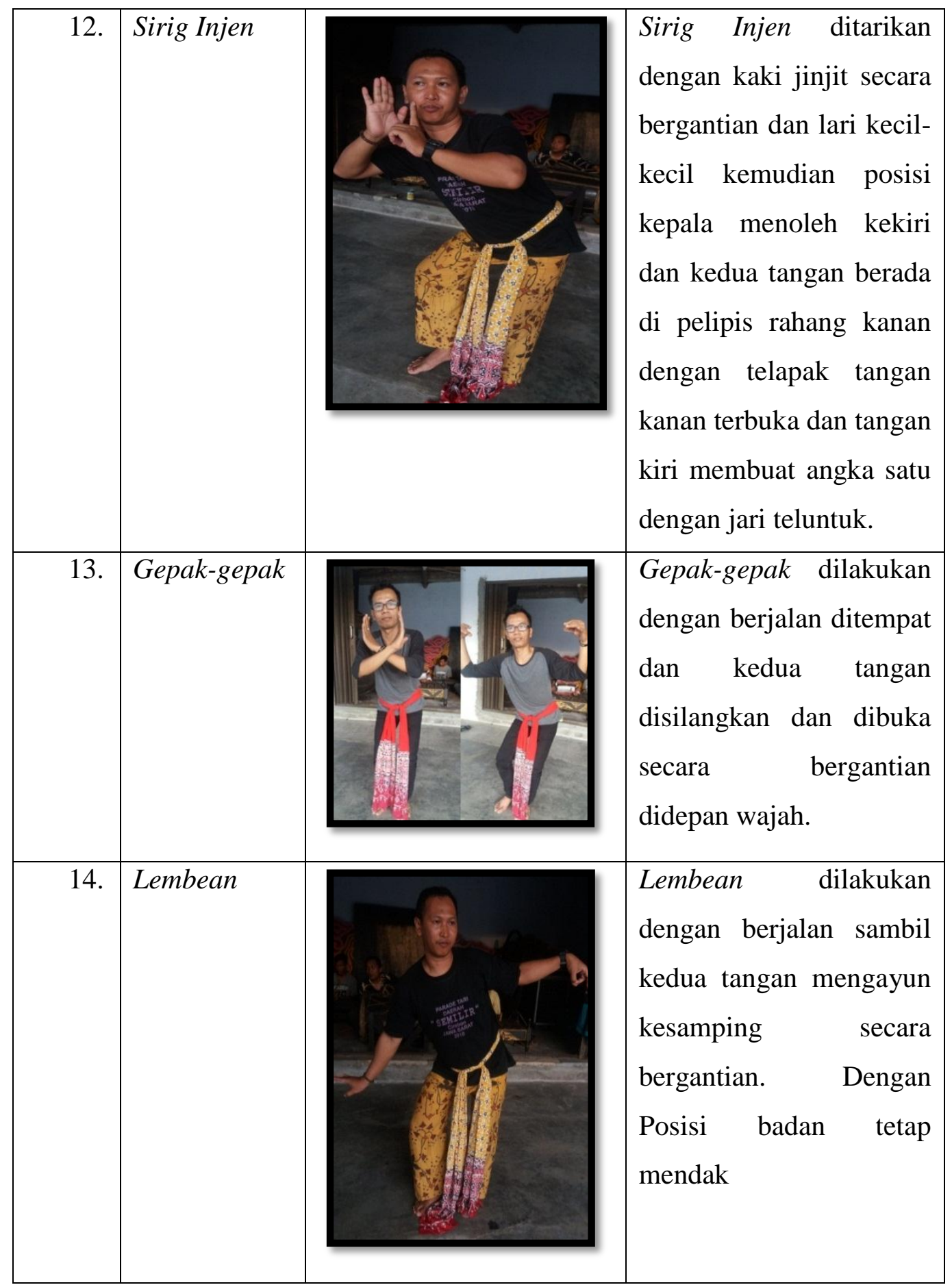




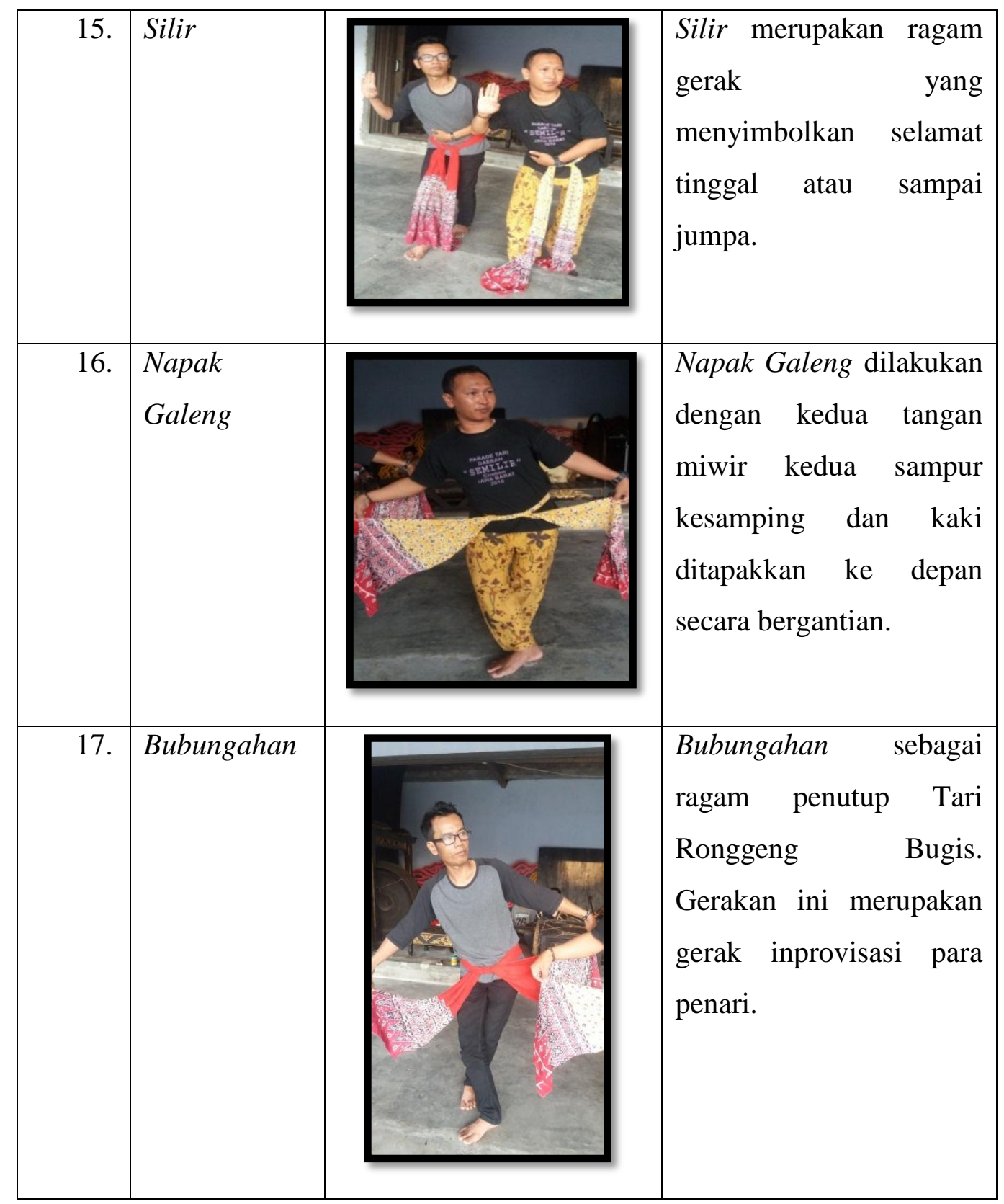

\subsubsection{Tata Busana atau Kostum Tari Ronggeng Bugis}

Kostum Penari Tari Ronggeng Bugis terdiri dari: kain jarit batik atau motif, kebaya, kestagen/stagen, kace, boro, anting-anting mainan, bandana kembang goyang/sanggul kembang goyang. kain dan baju kebaya yang harus 
dipakai penari tidak harus kain batik bermotif khas Cirebon yaitu motif mega mendung. Karena untuk mengangkat kebudayaa daerah Cirebon dengan motif kain batik mega mendung maka mayoritas sanggar yang ada di Cirebon termasuk Sanggar Pringgadhing menggunakan kain batik bermotif mega mendung. Sedangkan kebaya yang digunakan juga tidak paten harus kebaya jaman dahulu, namun dengan berkembangnya zaman kebayanyapun makin bervariasi. Yang terpenting adalah motifnya yang ramai dan warnanya yang cerah karena menggambarkan seorang wanita penyamar.

Busana atau kostum dan asesoris Tari Ronggeng Bugis meliputi : Kebaya berwarna terang, kain atau jarit yang bermotif bunga ataupun batik, sampur berwarna terang, kace untuk dibagian belakang, kace untuk dibagian depan, boro, sabuk, stagen, bando kembang goyang, dan anting2. Berikut gambar busana atau kostum Tari Ronggeng Bugis:

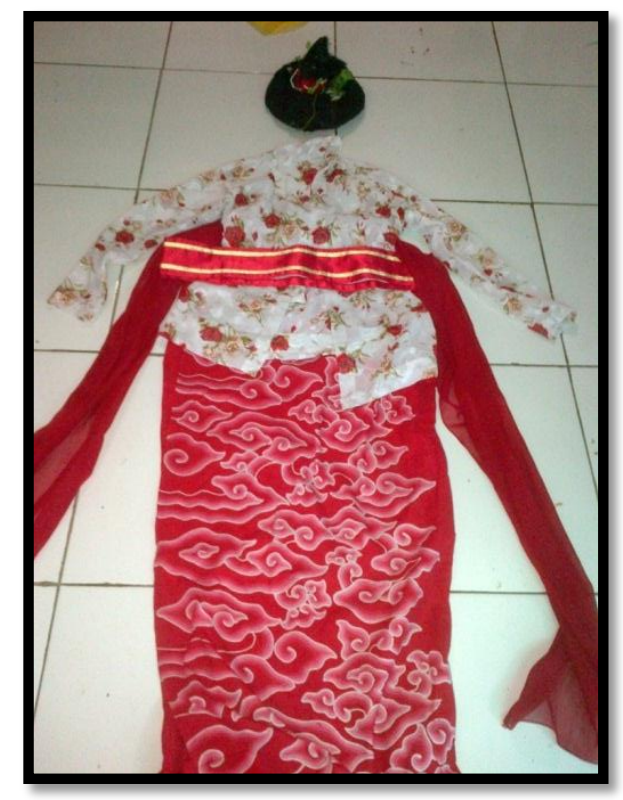

Gambar 2. Kostum tari Ronggeng Bugis sebelum berkembang (Foto : Rosdiana, 2017) 


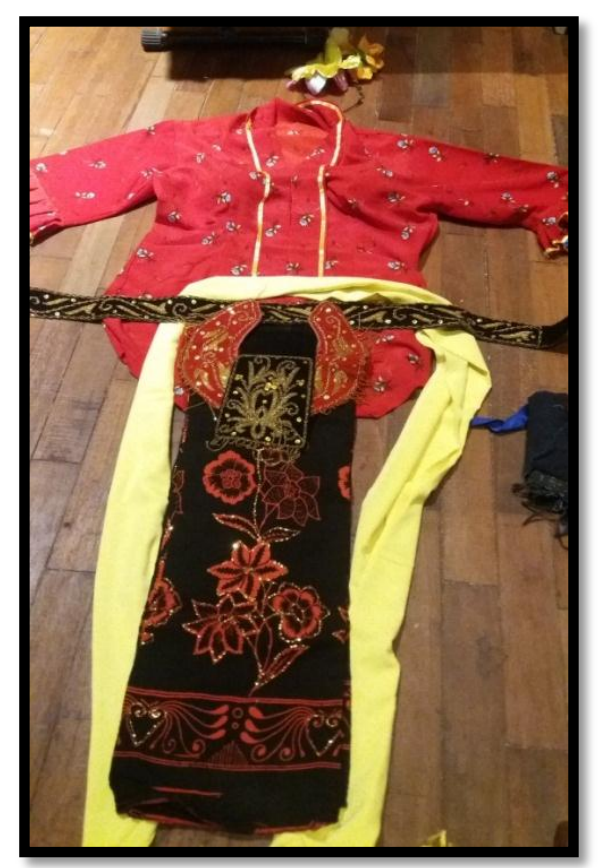

Gambar 3. Kostum tari Ronggeng Bugis saat tampil dalam acara Jaka Rara Cirebon

(Foto: Rosdiana, 2017)

1. Kebaya motif bunga berwarna merah

Dipilih sebagai pakaian pokok dalam tari Ronggeng Bugis. Kebaya motif berwarna merah kuning ini mengisyaratkan atau menggambarkan kegembiraan dan menjadi hiburan bagi para penikmat atau penonton. Kebaya yang digunakan tari Ronggeng Bugis Sanggar Pringgadhing umumnya bermotif bunga dan menggunakan warnawarna yang terang mencolok seperti warna merah, kuning, jingga, dan hijau. Model kebaya ini adalah kebaya kutu baru, dengan warna dasar merah, motif bunga biru dan sentuhan warna kuning dibagian lengan dan list warna kuning kebaya bagian kerah depan. 


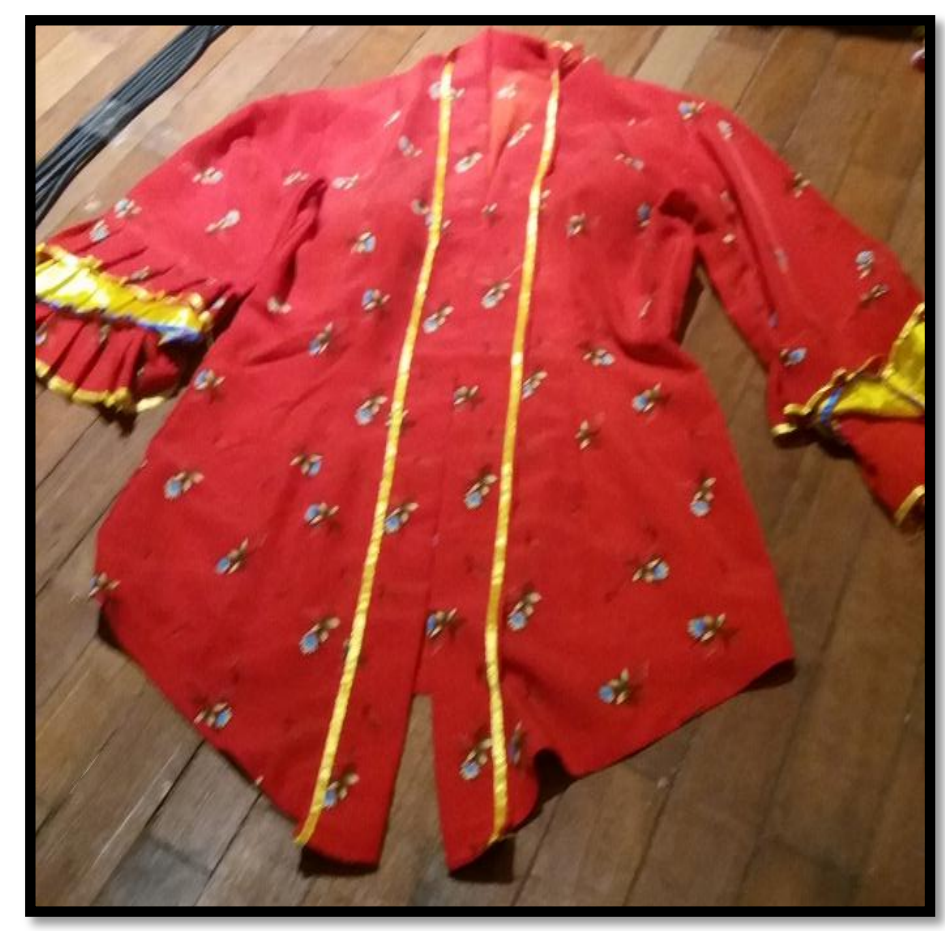

Gambar 4. Kebaya motif bunga

(Foto : Rosdiana, 2017)

2. Kain jarik bermotif bunga

Merupakan bagian pokok dalam kostum tari Ronggeng Bugis setelah kebaya. Kain jarik ini menggambarkan pakaian seorang wanita seharihari pada jaman dahulu. Kain jarik ini berbentuk persegi panjang, panjangnya hingga pergelangan kaki, dengan ukuran lebar antara $1 \mathrm{~m}$ sampai 1,1 $\mathrm{m}$ dan panjangnya sekitar 2,5 m. Pemakaian jarik pada tari Ronggeng Bugis dibuat seperti bentuk sarung agar lebih memudahkan penari dalam geraknya. Selain kain jarik motif bunga, Sanggar Pringgadhing juga memiliki kain jarik yang bermotif batik mega mendung sebagai ciri khas atau identitas dari daerah Cirebon. Kain jarik motif bunga ini didasari oleh warna hitam dengan motif bungabunga yang diberi warna merah. 


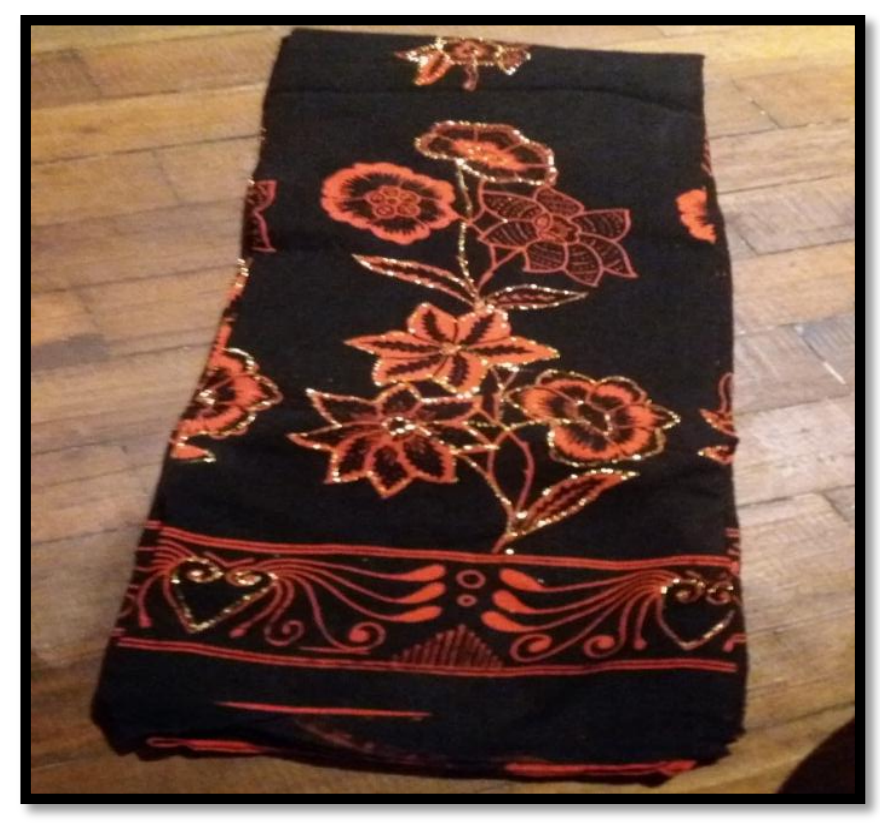

Gambar 5. Kain motif bunga

(Foto : Rosdiana, 2017)

3. Selendang berwarna kuning

Selendang atau sampur ini menjadi busana pokok setelah kebaya dan kain. Karena selendang identik dengan penari Ronggeng (penari wanita), selendang juga merupakan pelengkap pakaian wanita. Pada tari Ronggeng Bugis banyak gerakan yang menggunakan selendang. Selendang ini berbentuk persegi panjang dan biasanya mempunyai ukuran dengan lebar $45 \mathrm{~cm}$ adan panjangnya $150 \mathrm{~cm}$. Selendang yang digunakan untuk menari tari Ronggeng Bugis milik Sanggar Pringgadhing umumnya berwarna terang seperti, kuning, biru, dan merah dengan warna yang polos dan dihiasi dengan renda-renda di bagian samping atau diukuran lebar selendang. 


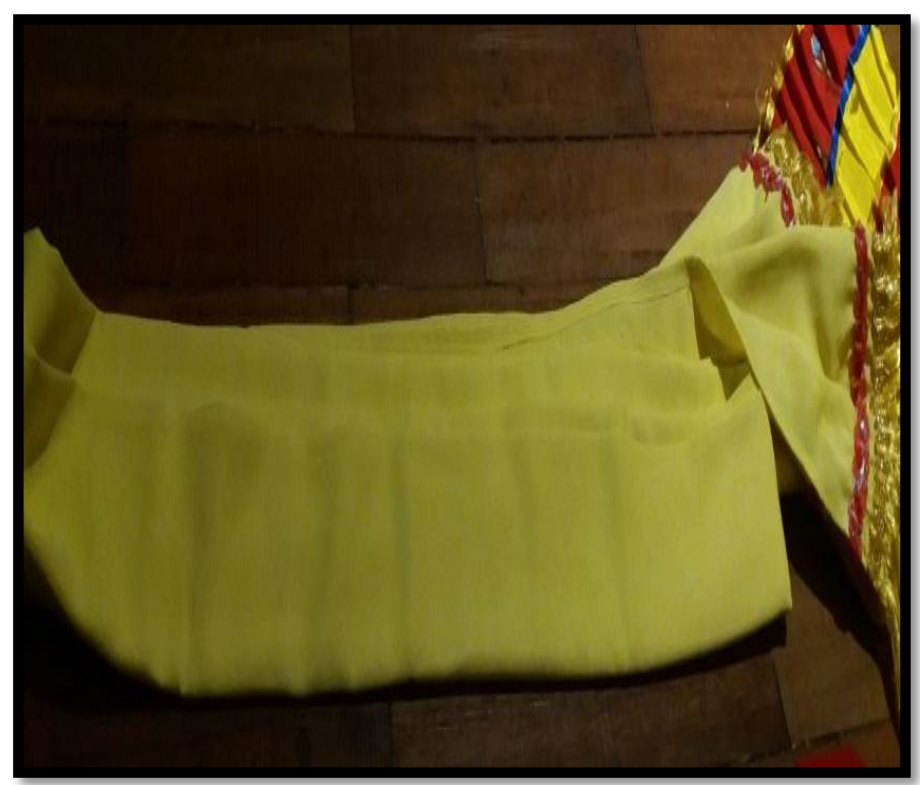

Gambar 6. Sampur berwarna kuning

(Foto : Rosdiana, 2017)

4. Kace berwarna merah dan hitam

Ialah kostum pendukung dalam tari Ronggeng Bugis. Kace yang berwarna hitam dan emas ini terbuat dari kain bludru dan digunakan dibagian belakang. Sedangkan kace berwarna merah digunakan dibagian depan. Kace juga merupakan kostum pengembangan tari Ronggeng Bugis, karena pada awal kemunculannya tari Ronggeng Bugis hanya menggunakan kebaya, jarit, dan sabuk. 


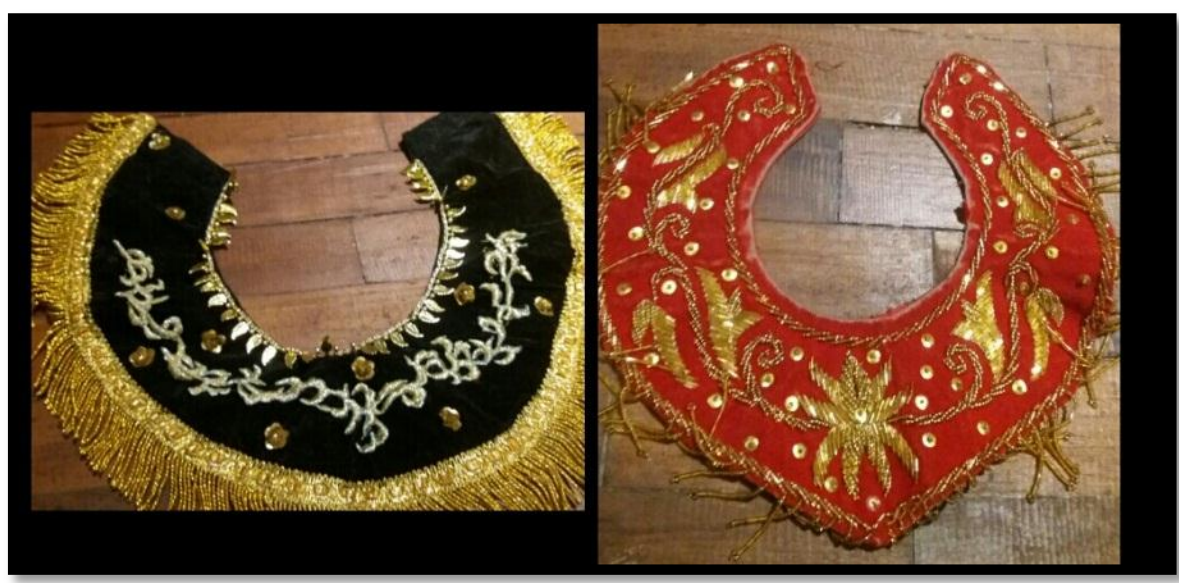

Gambar 7.Kace

(Foto : Rosdiana, 2017)

5. Boro

Ialah salah satu kostum tari Ronggeng Bugis yang merupakan pengembangan. Boro yang dikatakan oleh ketua sanggar ini terbuat dari kain bludru, dalam busana tari Ronggeng Bugis boro menggambarkan seorang prajurit dari Kasultanan. Boro digunakan dibagian depan tengah.

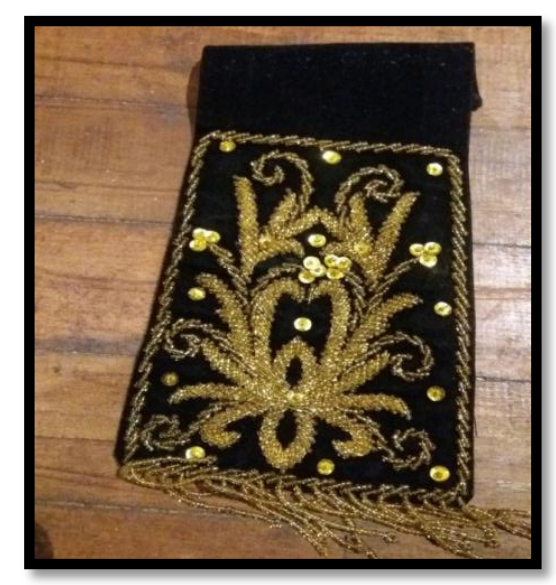

Gambar 8. Boro

(Foto : Rosdiana, 2017) 
6. Stagen

Stagen merupakan bagian penting dalam setiap tata busana tari termasuk dalam tata busana tari Ronggeng Bugis. Stagen adalah kain tenun dengan lebar sekitar 20-25 cm yang digunakan untuk mengeratkan atau menguatkan lilitan kain. Stagen memiliki panjang antara 3 hingga 10 meter dengan warna standar seperti putih, hitam, biru dongker, hijau dan kuning. Sedangkan stagen yang digunakan dalam tari Ronggeng Bugis menggunakan warna hitam atau biru dongker.

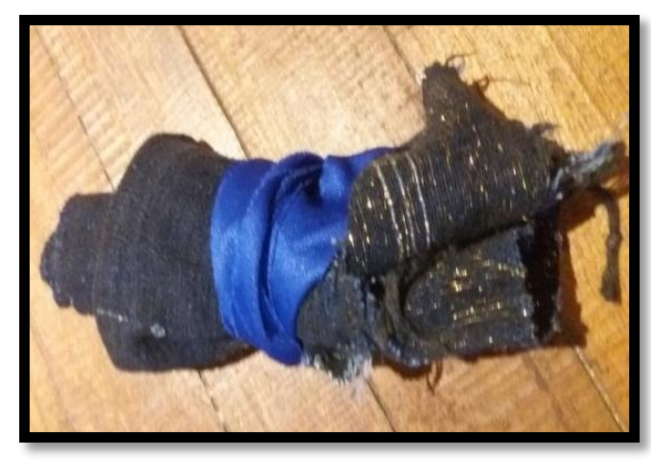

Gambar 10. Stagen

(Foto : Rosdiana, 2017)

\section{Sabuk}

Sabuk digunakan pada busana tari Ronggeng Bugis yang terbuat dari kain bludru selain kace, dan boro. Sabuk dalam tari Ronggeng Bugis menggambarkan kekuatan dan kekompakan yang terjalin antar prajurit yang sangat erat. Sabuk diletakan dipinggang untuk membuat hiasan pada kain, selain sebagai pengikat. 


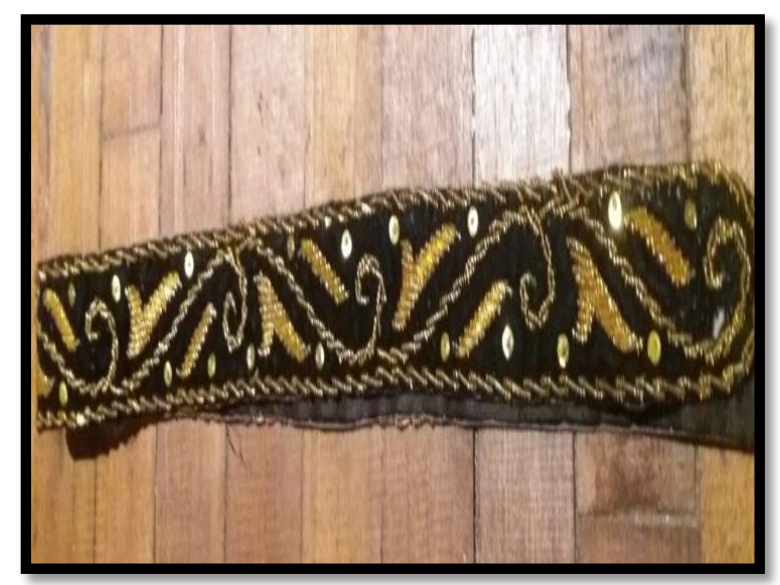

Gambar 9. sabuk

(Foto : Rosdiana, 2017)

8. Bando kembang goyang

Bando kembang goyang ini menjadi pengganti sanggul. Saat awal kemunculannya tari Ronggeng Bugis menggunakan rias kepala dengan sanggul untuk menutupi rambut penari laki-laki. Namun saat ini dengan telah berkembangnya tari Ronggeng Bugis di Sanggar Pringgadhing mulai terbiasa menggunakan bando kembang goyang agar lebih simpel dan nyaman digunakan oleh para penari yang notabene laki-laki. Dan jika rambut penari panjang maka tinggal diikat atau dicepol kemudian dipasang dengan bando kembang goyang. Bando kembang goyang juga merupakan asesoris sebagai pelengkap kostum tari Ronggeng Bugis. 


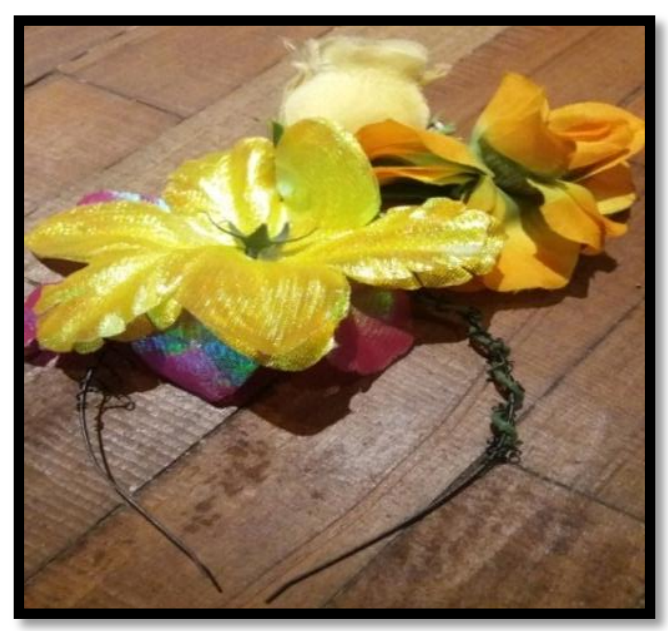

Gambar 11. Bando Kembang Goyang

(Foto : Rosdiana, 2017)

\section{Anting-anting}

Anting menjadi bagian penting pula dalam penyamaran tari Ronggeng Bugis, karena anting pasti menjadi ciri seorang wanita. Anting dalam hal ini berfungsi untuk menggambarkan penyamaran laki-laki menjadi perempuan, anting menjadi pelengkap tata busana dan kostum dalam tari Ronggeng Bugis sebagai asesoris.

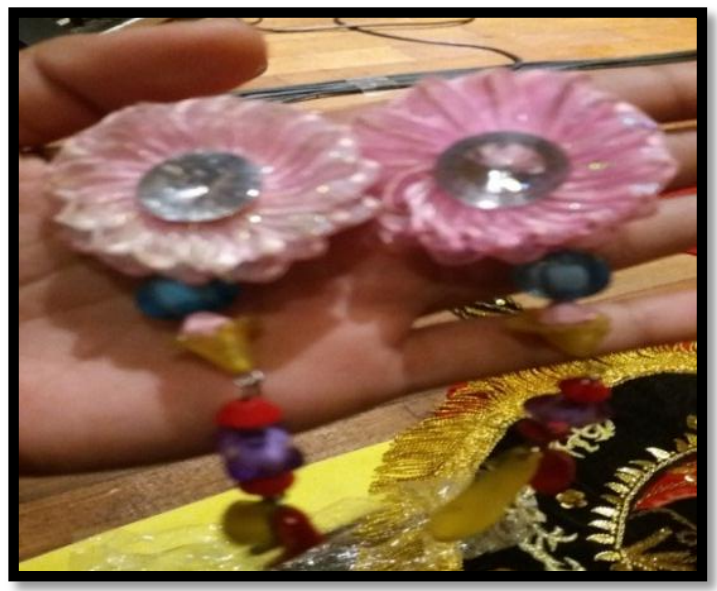

Gambar 12. anting-anting

(Foto : Rosdiana, 2017) 


\subsubsection{Tata Rias Make Up Tari Ronggeng Bugis}

Tata rias make up dalam Tari Ronggeng Bugis adalah rias karakter badut, rias wajah penari dibuat mencolok dengan rias wajah para penari dibuat seperti make up karakter badut atau pemain pantomim, dengan lukisan atau rias jenaka yang berkaitan dengan fungsi dan tema dari tari Ronggeng Bugis yaitu sebagai hiburan.

Tata rias merupakan unsur yang berperan penting dalam setiap pertunjukan tari Ronggeng Bugis. Rias badut yang terlihat mencolok dibagian wajah yang dibuat lucu dengan memakai bedak yang sangat putih dan tebal, kemudian kedua pipi dengan pemerah pipi yang mencolok dibentuk bulat, memakai lipstik berwarna merah dengan bentuk yang keluar dari garis bibir asli dan rias alis yang tidak simetris. Sehingga rias wajahnya terlihat lucu, mengelitik yang akan mengundang gelak tawa bagi para penonton yang melihatnya.

Dalam acara Jaka Rara Kota Cirebon 2017 yang dilaksanakan di Hotel Swissell pada tanggal 21 Mei 2017 lalu Sanggar Pringgadhing menampilkan tari Ronggeng Bugis dengan enam penari dengan make up yang digunakan ialah rias karakter badut. Perlu diketahui bahwa riasan wajah dalam tari Ronggeng Bugis, berapapun penarinya dalam setiap pementasan, pasti menggunakan rias karakter badut pada setiap penarinya dengan rias yang berbeda dibagian garis-garis dibagian mata, garis-garis dibagian mulut dan tahi lalat buatan, itu tidak menunjukan perbedan karakter atau adanya tokoh dalm setiap penari, namun rias wajh ini hanya untuk menunjang penampilan agar kesan lucu dan humor tari Ronggeng Bugis semakin kuat dan lebih muncul. 

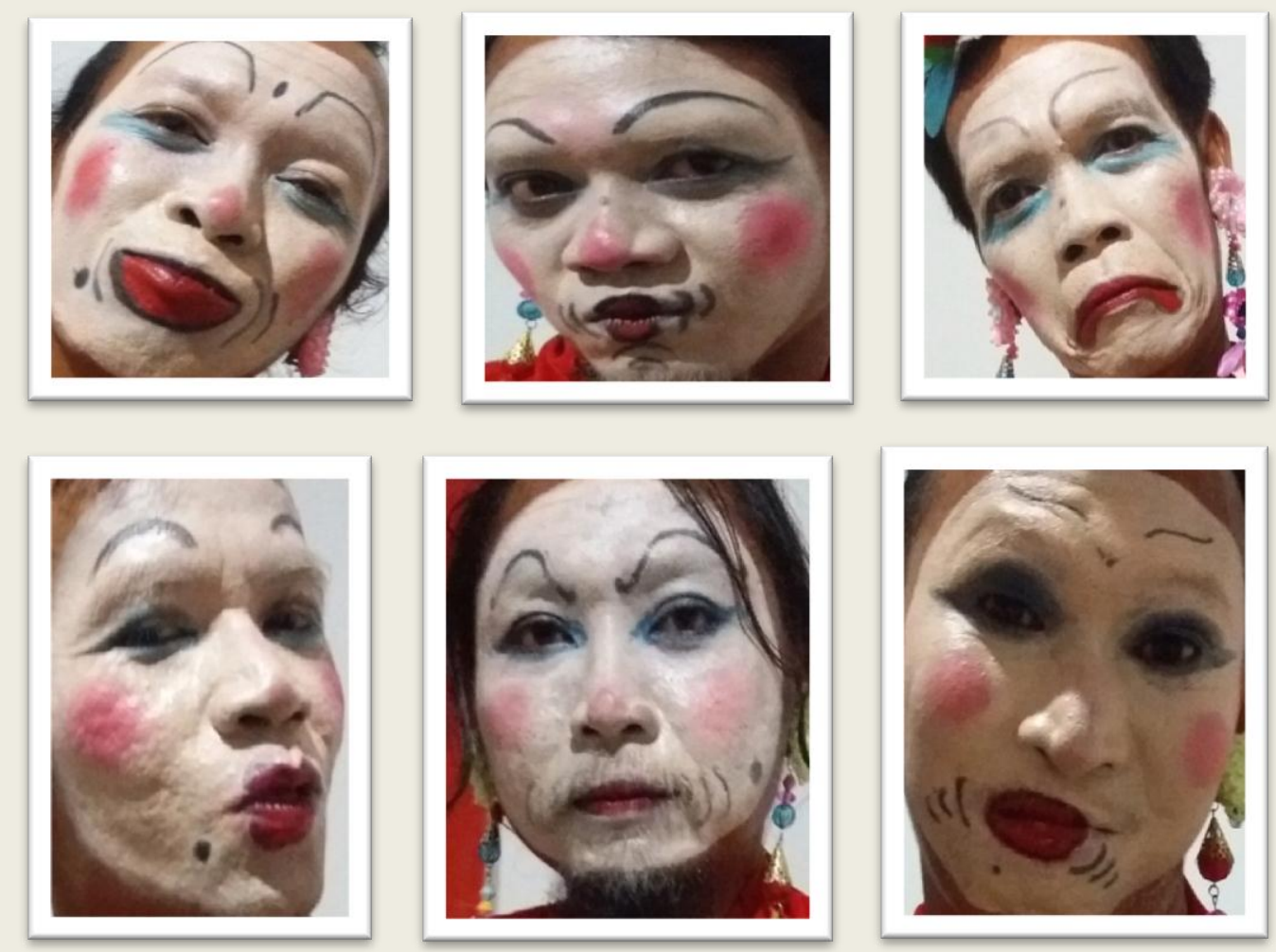

Gambar 13. Rias Karakter badut untuk tari Ronggeng Bugis

(Foto: Rosdiana, 2017)

\subsubsection{Musik Pengiring Tari Ronggeng Bugis}

Iringan merupakan satu kesatuan yang tidak dapat dipisahkan dalam suatu tarian. Musik iringan yang digunakan tari Ronggeng Bugis menggunakan iringan Improvisasi dari beberapa alat musik tradisional Cirebon. Musik yang digunakan untuk mengiringi Tari Ronggeng Bugis merupakan musik eksternal, disebut eksternal karena semua musik berasal dari luar diri penari yaitu semua musik berasal dari pemain musik baik musik yang dimainkan dengan alat musik maupun dengan suara sorak-sorai para pemain musik. Karena Tari Ronggeng Bugis dapat dipentaskan tidak hanya diatas panggung namun sering juga dipentaskan dalam bentuk Halaran maka alat musik yang dimainkanpun berbeda dan jumlah alat 
musik yang diatas panggung biasanya menggunkaan gamelan lengkap, jika dalam bentuk halaran musik yang digunakan untuk mengiringi tari Ronggeng Bugis hanya beberapa alat musik saja . Alat musik yang dimainkan berasal dari gamelan Cirebon bukan gamelan sunda, yang menggunakan laras pelog.

Bunyi tabuhan musik iringan dalam tari Ronggeng Bugis ikut mewarnai dan menegaskan situasi komunikasi dengan hentakan music yang dapat membawa emosi para penari maupun penonton, karena bisa mengantarkan makna atau pesan yang ada di dalam tari Ronggeng Bugis, bunyi tabuhan yang menghentak dan semangat dapat menggambarkan dan membangkitkan jiwa heroisme bagi para penarinya. (Wawancara dengan Bapak Windu, 19 Mei 2017)

Berikut notasi musik pengring tari Ronggeng Bugis dan nama-nama instrumen musik pengiring yang digunakan untuk mengiringi Tari Ronggeng Bugis ialah: Bonang, kempyang, kendang sunda, gong, kempul, kecrek, klenang, dan kendang ketipung,. Berikut notasi music iringan tari Ronggeng Bugis:

Saron, Bonang, Kemyang:

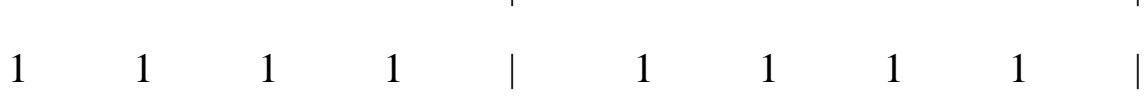

Kenong:

1 1 1 1 
Kebluk:
$\mathrm{D}$
D |
$\mathrm{D}$
D

Kiwul:

K $\quad$ K $\quad$ | $\quad$ K $\quad$ K

Keterangan:

$1=$ nada $\mathrm{ji} /$ laras

$2=$ nada ro $/$ miring

$\mathrm{D}=$ Dung (kebluk)

$\mathrm{K}=\mathrm{Kung}$ (kiwul/gong kecil)

Berikut gambar alat-alat musik yang ada di Sanggar Pringgadhing yang digunakan untuk mengiringi Tari Ronggeng Bugis.

1. Saron

Saron merupakan alat musik tradisional jawa yang terbuat dari bahan logam perunggu, dan cara memainkannya yaitu dengan dipukul menggunakan alat bantu pemukul yang terbuat dari kayu dengan bentuk seperti palu. Biasanya saron terdiri dari 4 buah dalam satu set gamelan. Cepat lambatnya tabuhan pada saron tergantung dari komando kendang dan jenis gendhingnya. 


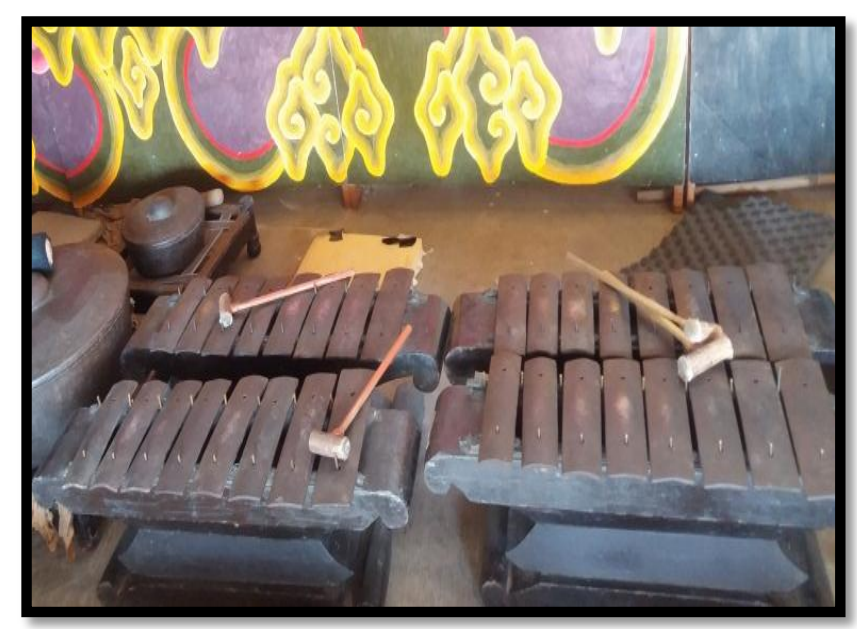

Gambar 14. Saron

(Foto: Rosdiana, 2017)

\section{Bonang}

Bonang merupakan salah satu alat musik yang digunakan dalam gamelan

Jawa. Bonang juga merupakan instrumen melodi terkemuka di Degung

Gamelan Sunda. Cara memainkannya yaitu dengan cara dipukul atau ditabuh pada bagian atasnya yang menonjol atau disebut dengan pencu (pencon) dengan menggunakan dua pemukul khusus yang terbuat dari kayu yang dibungkus dengan kain atau disebut bindhi. Bonang yang terdapat di Sanggar Pringgadhing merupakan bonang yang terdapat dalam instrumen gamelan Cirebon. Bentuknya berbeda dengan bonang Jawa dan Bali maupun degung Sunda. Namun bunyi yang keluar sama. 


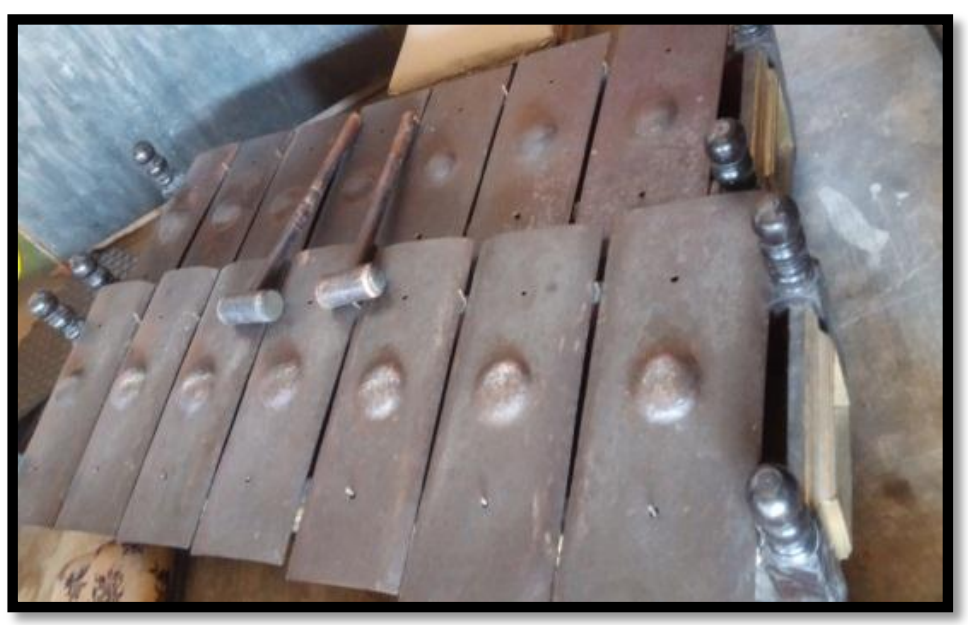

Gambar 15. Bonang

(Foto: Rosdiana, 2017)

\section{Kemyang}

Kemyang atau kempyang yang biasa disebut dalam gamelan jawa. Bentuk kemyang Cirebon berbeda dengan kempyang Jawa. Cara untuk menabuh kemyang yaitu dengan dibantu alat pukul yang terbuat dari kayu yang berbentuk seperti palu.

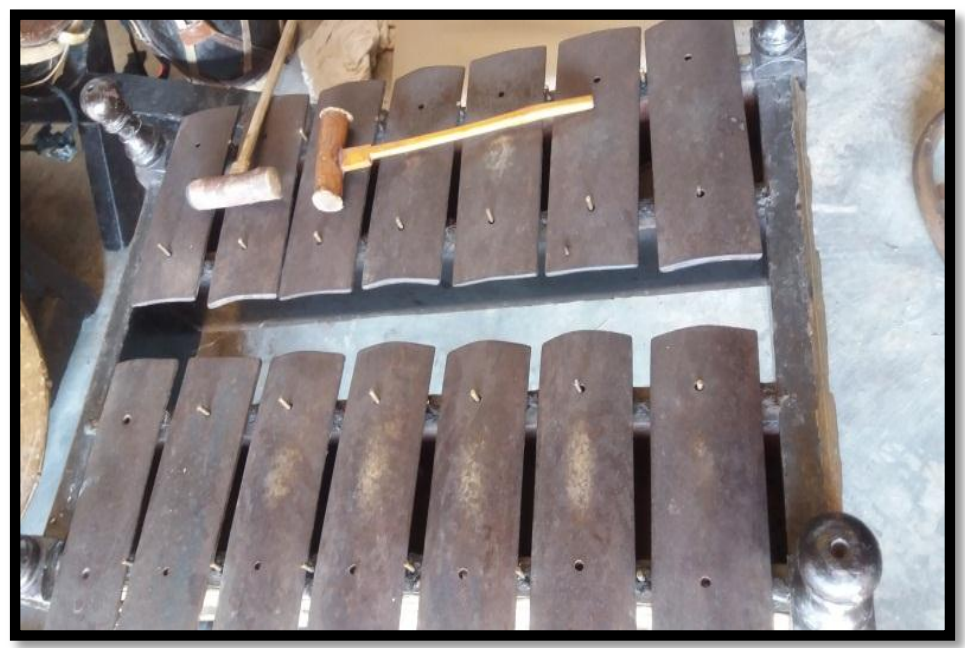

Gambar 16. Kemyang

(Foto: Rosdiana 2017) 
4. Kebluk/tutukan

Ialah salah satu jenis alat musik yang berfungsi untuk menuntun ketetapan irama lagu yang tengah dimainkan oleh para pemain musik. Kalau dalam gamelan Jawa tutukan atu kebluk ini disebut dengan ketuk. Kebluk juga biasa dipukul dengan menggunakan alat yang terbuat dari kayu yang dilapisi kain.

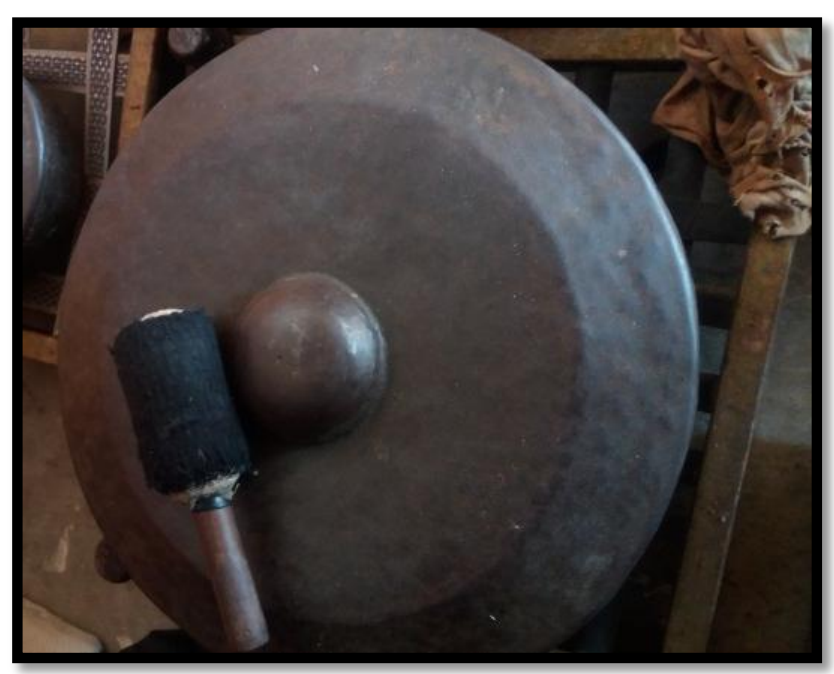

Gambar 17. Kebluk/tutukan

(Foto: Rosdiana, 2017)

\section{Kendang Ketipung Sunda}

Ialah alat musik pokok yang ada pada tari Ronggeng Bugis. Kendang Ketipung menjadi penentu dalam alunan musik untuk mengatur tempo, yang mengatur dan mengendalikan irama tabuhan yang disajikan di awal maupnu diakhir pertunjukan. Selain itu pula mempunyai peranan sebagai mitra untuk menata ritme atau memperkuat gerak yang ditampilkan penari, kendang ketipung juga sebagai penentu suasana dalam tarian. 


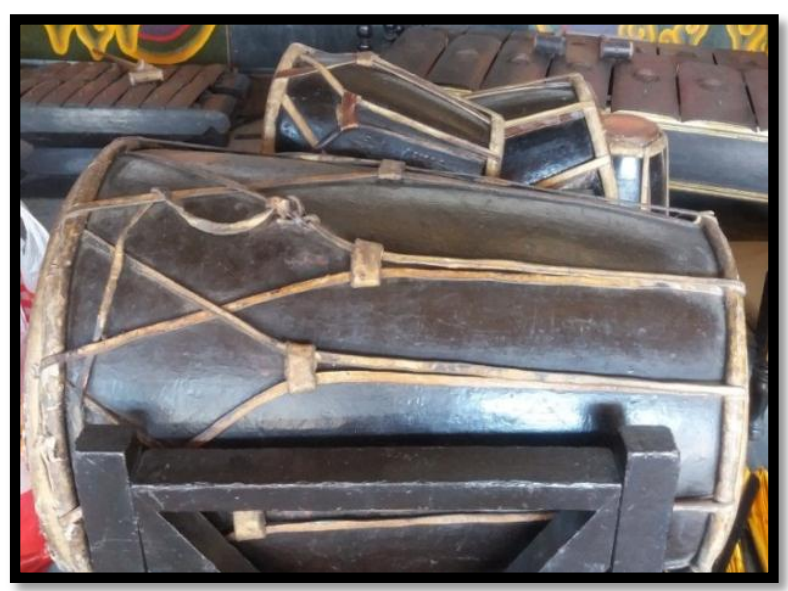

Gambar 18. Kendang ketipung

(Foto: Rosdiana, 2017)

\section{Gong Kecil/Kiwul}

Ialah salah satu alat musik pengiring tari Ronggeng Bugis yang terbuat dari kuningan, ada juga yang terbuat dari tembaga yang berbentuk bulat dan ditengahnya terdapat penclo, teknik menabuhnya dipukul memakai alat pukul gong yang berasal dari kayu dengan kepala pukul menggunakan bahan seperti gulungan kain, gong kecil/kiwul berperan sebagai pengakhir disetiap bait lagu.

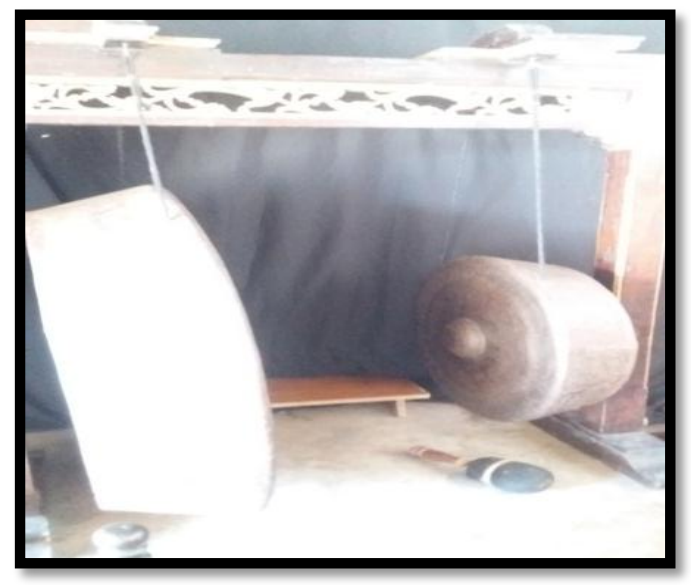

Gambar 19. Gong Kecil/Kiwul

(Foto: Rosdiana, 2017) 


\section{Kecrek}

Ialah merupakan alat musik pendukung yang memberi variasi dalam iringan tari Ronggeng Bugis atau memberi warna pada ritme-ritme yang digarap oleh penabuh ketipung. Yang terbuat dari lempengan besi dengan jumlah tiga lembar yang dialasi dengan kayu, teknik menabuhnya dipukul oleh pemukul yang terbuat dari kayu.

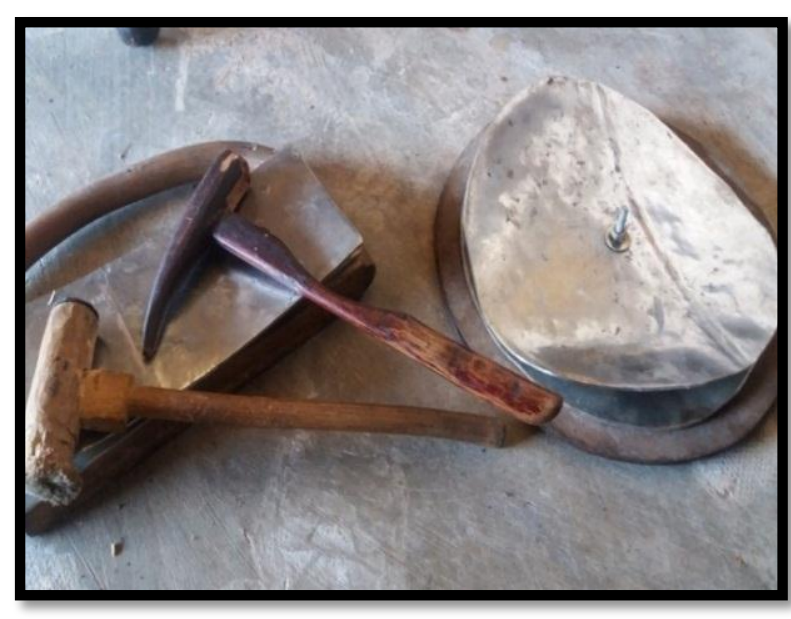

Gambar 20. Kecrek

(Foto: Rosdiana, 2017)

8. Klenang

Ialah alat musik pendukung dalam musik iringan tari Ronggeng Bugis. Klenang biasa digunakan saat pertunjukan tari Ronggeng Bugis yang dihelarkan atau helaran, karena lebih mudah untuk dibawa dan bunyinya juga sudah ramai, jadi klenang adalah alat musik yang digunakan untuk mengiringi tari Ronggeng Bugis pada saat pementasan di jalan raya, lapangan terbuka, pawai atau Car Free day. 


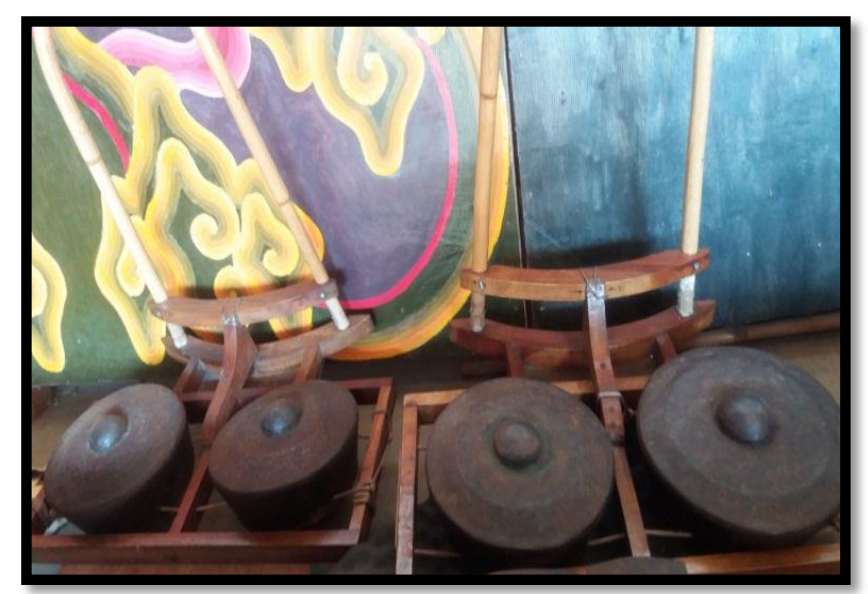

Gambar 21. Klenang

(Foto: Rosdiana, 2017)

\subsubsection{Tempat Pertunjukan}

Tempat pertunjukan tari Ronggeng Bugis biasanya disebut dengan nama halaran atau pawai yang biasa ditampilkan di jalan raya atau tempat umum dan di panggung terbuka seperti yang ada di Gua Sunyaragi Cirebon. Namun setelah diakui sebagai tarian tradisi Cirebon dan hidup di dalam keraton, berkat bapak Handoyo (alm) akhirnya tari Ronggeng Bugis diangkat menjadi tari pertunjukan di atas panggung dengan kemasan gerak dan busana yang artistik. Panggung pertunjukan yang biasa digunakan untuk pementasan tari Ronggeng Bugis berbentuk panggung terbuka. Pangugung (pentas) terbuka berarti panggung berada di udara terbuka. Biasanya tidak ada batasan atau jarak antara penari dan penonton jika dipentaskan secara halaran, dan dapat pula diadakan disebuah panggung yang tinggi atau landai dimana penonton berada di bawah atau di depan tempat tersebut. Seperti beberapa gambar di bawah ini yang menjadi tempat pertunjukan tari Ronggeng Bugis. 


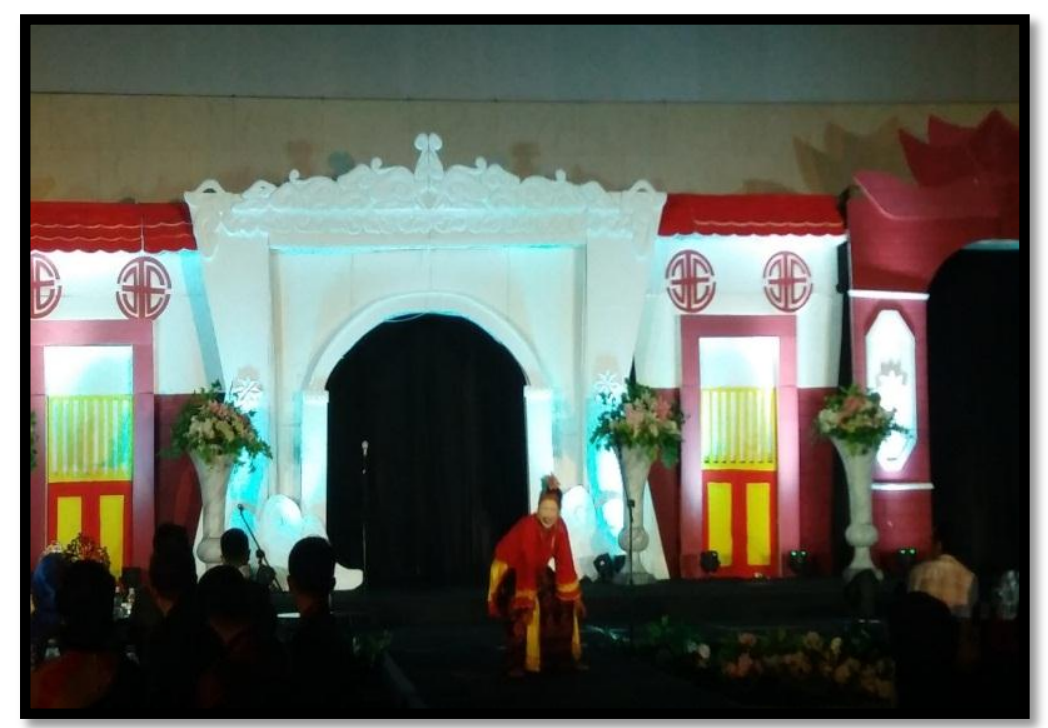

Gambar 22. Panggung Pertunjukan Tari Ronggeng Bugis saat acara Jaka Rara Kota Cirebon.

(Foto : Rosdiana, 2017)

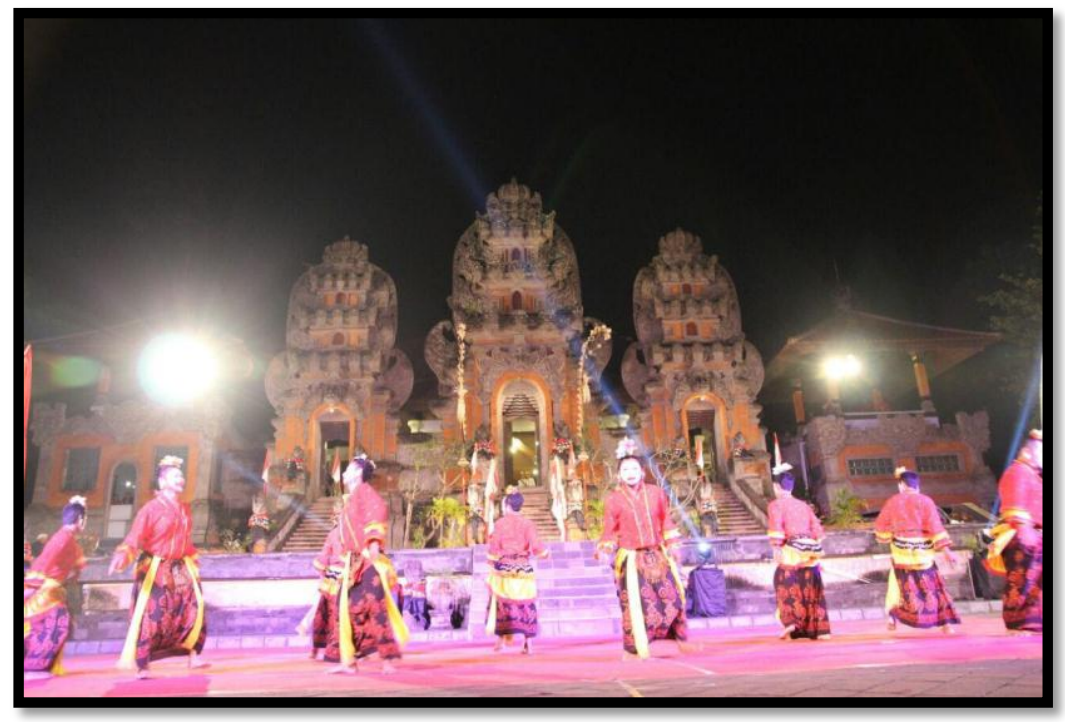

Gambar 23. Tari Ronggeng Bugis di Panggung Terbuka acara ulang tahun Gianyar Bali 2017

(Foto: Windu, 2017) 


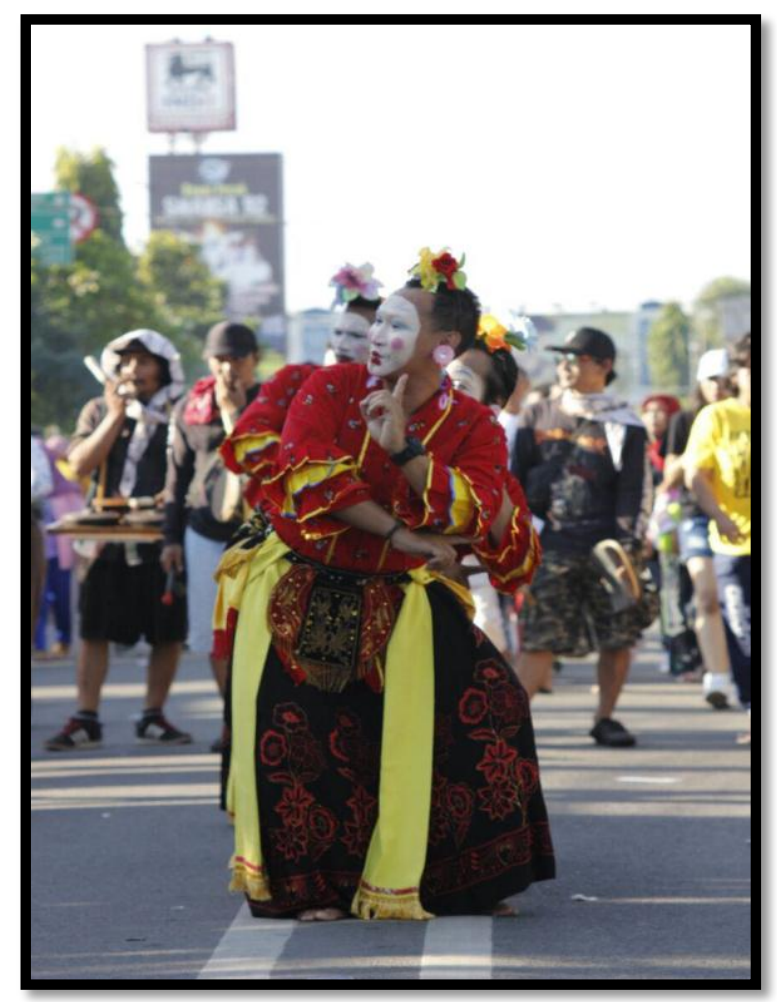

Gambar 24. Helaran Car Free Day di Siliwangi Cirebon

(Foto: Windu, 2017)

\subsubsection{Apresiator}

Penonton adalah bagian dari apresiator yang merupakan salah satu penentu Tari Ronggeng Bugis eksis atau diakui keberadaannya dimasyarakat dan disukai oleh masyarakat khususnya penikmat seni. Disetiap pertunjukannya, Tari Ronggeng Bugis selalu menjadi salah satu tarian yang ditunggu-tunggu karena tariannya yang lucu sehingga dapat memnghibur para penonton. Sanggar Pringgadhing mempunyai cara tersendiri untuk menempatkan Tari Ronggeng Bugis disetiap pertunjukanya.

Tari Ronggeng Bugis ditampilkan menjelang penutup atau closing setiap acara. Ini menjadi salah satu cara agar penonton tetap berada di tempat 
pertunjukan sampai akhir acara dan menunggu-nunggu penampilan apik dari Tari Ronggeng Bugis, tarian jenaka yang pasti menghibur. Dari awal penampilan sampai akhir penonton dibuat tertawa seolah menikmati tarian tersebut. Selain itu para penari selalu melibatkan penonton untuk ikut menari bersama dalam sebuah adegan tari yang berpasangan. Penonton dibuat tertawa sepanjang tarian karena tingkah lucu dan konyol para penari. Maka disetiap pertunjukan Sanggar Pringgadhing pasti tari Ronggeng Bugis menjadi salah satu tarian yang ditunggutunggu oleh masyarakat atau penonton.

Para penonton akan menikmati sajian cerita, gerak-gerak tubuh penari, musik, dan unsur-unsur seni yang hadir untuk menunjang pertunjukan tari Ronggeng Bugis. Penonton merasakan kegembiraan dalam hatinya atas pertunjukan yang diapresiasi sesuai dengan pengalaman dan perasaan mereka. Dalam seni, tentu adakalanya seni pertunjukan pada satu wilayah yang sama atau daerah yang sama, tidak bisa dipaksakan untuk diapresiasi oleh seluruh masyarakat yang ada dalam satu daerah tersebut, tidak semua masyarkat di daerah tersebut mengenal tari Rongeng Bugis. Disini bisa disimpulkan bahwa seni pertunjukan akan selalu ditonton, diapresiasi dan dapat berkomunikasi dengan publik seni itu sendiri yang memiliki minat, kepentingan, atau kegemaran yang sama, namun seni tersebut akan tetap ada dan bertahan dengan sendirinya jika pelaku melestarikan bahkan bisa mengembangkanya seperti tari Ronggeng Bugis yang sampai saat ini masih hidup dan diakui keberadaannya oleh masyarakat serta sudah bisa berkembang (wawancara dengan Bapak Taufan dan Adi dalam acara Jaka Rara Kota Cirebon, 21 Mei 2017). Kutipan wawancara sebagai berikut: 
"Tari Ronggeng Bugis menurut bebrapa penonton yang diwawancarai mengatakan kalau tari Ronggeng Bugis tarian yang lucu, pasti membuat ketawa para penonton yang melihat. Saya menyukai tarian ini. Tariannya tidak membosankan karena tarian ini jenaka dan yang menarikan laki-laki namun dengan menirukan gerakan perempuan. Tarian ini menurut saya diminati oleh masyarakat Cirebon. Tari Ronggeng Bugis lucu, bagus, saya suka melihatnya. Sayapun tak menyesal jauh-jauh dari Cirebon Timur untuk menghadiri acara ini, dan ternyata ada tarian humor yang dimiliki oleh Cirebon. tari ini bisa ditonton untuk semua umur. Adi saja yang hadir bukan hanya mahasiswa dan orang-orang dewasa. Tapi dari anak-anak juga dan mereka semua merasa terhibur dan tidak jenuh saat melihat tari Ronggeng Bugis.”

Tari Ronggeng Bugis dikemas menjadi tari tradisi Cirebon yang memiliki aspek pertunjukan meliputi gerak, jumlah penari, iringan, tata busana, tata rias, dan tempat pertunjukan yang berbeda dengan sanggar-sanggar lain, selain yang pertama mengangkat tari Ronggeng Bugis menjadi sebuah tari Pertunjukan merupakan pendiri Sanggar Pringgadhing, kemudian dengan adanya kemasan disetiap bentuk penyajian tari Ronggeng Bugis di Sanggar Pringgadhing berbeda dengan sanggar lain. Diantaranya perbedaan bentuk penyajian yang dibawakan pada saat pentas dipanggung Halaran dan di Panggung Pertunjukan. Saat di Halaran pembukaan tari Ronggeng Bugis diawali dengan para penari yang menyebar disela-sela penonton sehingga dapat mebuat penonton untuk ikut menari bersama. Sedangkan pada saat pentas di atas panggung pertunjukan biasanya dibacakan synopsis tarian, kemudian suara musik terlebih dahulu dan keluar satu penari yang berperan sebagai komandan dan diikuti oleh penari lain dengan menari secara rampak.

Untuk bisa membuat tari Ronggeng Bugis di Sanggar Pringgadhing tetap bertahan eksistensinya dan hidup dimasyarkat luas sebagai tari tradisi asli Cirebon, salah satu cara agar tari Ronggeng Bugis tetap eksis tanpa meninggalkan 
atau melupakan keaslian dari sejarahnya maka di atas telah dibahas bentuk pertunjukannya dimana tari Ronggeng Bugis di Sanggar Pringgadhing tetap ditarikan oleh laki-laki dengan gerak perempuan, menggunakan rias dan busana seperti penari wanita namun dengan rias karakter yang lucu dan bisa di pentaskan di atas panggung pertunjukan maupun dalam pertunjukan helaran atau pawai sehingga tetap menjadi tarian yang menghibur dan disukai banyak penonton.

Eksistensi tari Ronggeng Bugis dikatakan pula oleh wali murid yang anaknya belajar di Sanggar Pringgadhing, mereka merasa bangga jika anak mereka dapat menarikan tari Ronggeng Bugis, karena tariannya yang lucu sehingga dapat menghibur banyak orang. Selain itu anak-anak mereka bisa membawa nama baik sekolahnya karena tari Ronggeng Bugis yang biasanya dilombakan di Cirebon atau mengisi dalam acara pentas seni di sekolah mereka.

\subsubsection{Penyebarluasan Tari Ronggeng Bugis}

Tari Ronggeng Bugis dikatakan eksis atau keberadaannya tetap diakui oleh masyarakat maka salah satu caranya dengan menyebarluaskan tari Ronggeng Bugis ke berbagai tempat agar dikenal oleh masyarakat Cirebon khsususnya mulai dari kalangan seniman, krkitikus seni maupun masyarkat biasa pada umumnya. Penyebarluasan tari Ronggeng Bugis di Sanggar Pringgadhing yaitu dengan cara mengajarkannya di sanggar tetapi hanya pada anak-anak yang meminta untuk belajar tari Ronggeng Bugis. Kemudian selain mengajarkan di sanggar, para penari tari Ronggeng Bugis juga menjadi pelatih eksrakurikuler (eskul) di Sekolah. Beberapa sekolah yang mempelajari tari Ronggeng Bugis ialah SMKN 1 Kedawung, SMA 1 Sumber, dan SMK N 1 Mundu. Sehingga dengan cara 
penyebarluasan ini maka tari Ronggeng Bugis dikenal oleh anak-anak atau siswa sekolah.

Tari Ronggeng Bugis disebarluaskan tidak hanya melalui sekolah-sekolah melainkan sudah masuk dan dijadikan materi pembelajran dikalangan kampus seni yang ada di Jawa Barat yaitu di Kampus Universitas Pasundan.Bandung. Tari Ronggeng Bugis di Sanggar Pringgadhing milik bapak Handoyo (alm) juga dijadikan obyek penelitian bagi penelitian mahasiswa atau dosen Perguruan Tinggi Seni maupun keguruan. Selain itu sebagai wujud pelestarian, inovatif dan transformasi tari tradisional Cirebon dan sebagai upaya mempertahankan eksistensi tari Ronggeng Bugis. Hal ini dikaitkan dengan penuturan dari para penari Ronggeng Bugis. Kutipan wawancara sebagai berikut:

"Upaya para seniman atau pelaku seni tari Ronggeng Bugis dalam melestarikan tari Ronggeng Bugis agar tetap hidup dimasyarakat khususnya untuk seniman di Sanggar Pringgadhing yaitu salah satu caranya, kalau saya sendiri karena sudah mengikuti Sanggar Pringadhing sejak kecil, saat masih ada Pak Handoyo (alm) sampai saat ini dipimpin oleh anaknya, dan saya masih menjadi penari Rongeng Bugis mungkin itu sudah menjadi dedikasi dan salah satu cara saya ikut melestarikannya".

Selain itu kami juga sering dimintai menjadi pengajar tari untuk ekstrakurikuler di sekolah-sekolah, kemudian ada juga yang menjadikan tari Ronggeng Bugis di Sanggar Pringadhing sebagai objek penelitian mahasiswa, yang saya tahu sudah ada dari bandung, jogja, dan sekarang baru dari semarang meneliti tari Ronggeng Bugis".

(wawancara dengan penari Ronggeng Bugis, Bapak Dayat dan Bapak Wili, 19 Mei 2017).

Pada saat ini di tahun 2017 masyarakat Jawa Barat pada umumnya dan masyarakat Cirebon khususnya telah banyak dipengaruhi oleh sentuhan-sentuhan teknologi modern. Namun demikian kebiasaan-kebiasaan atau adat istiadat yang merupakan tradisi turun-temurun atau kebudayaan tetap terpelihara dan dilaksanakan meskipun oleh kalangan-kalangan terentu saja. 
Sebagai contoh dalam proses upacara adat perkawinan berbagai unsur budaya yang telah dikenal terakumulasi secar selektif. Biasanya acara yang paling meriah adalah ketika akad nikah, saat penyambutan kehadiran calon pengantin pria beserta keluarganya sengaja dibuat acara khusus yang lazim disebut prosesi penyambutan pengantin. Tampaknya acara prosesi penyambutan pengantin telah dimasukan dalam adat perkawinan di Cirebon, dan Handoyo (alm) seorang creator seniman Cirebon pendiri Sanggar Pringgadhing menjadikan itu sebagai peluang untuk mengenalkan tari Ronggeng Bugis pada masyarakat luas dengan cara yang berbeda.

Tari Ronggeng Bugis yang disajikan pada prosesi upacara penyambutan calon pengantin, adalah model prosesi produk Sanggar Pringgadhing dengan penata tari bapak Handoyo (alm). Prosesi upacara adat penyambutan pengantin dengan tari Ronggeng Bugis tersebut ternyata laku dipasaran terutama dikalangan masyarakat yang berkecukupan dan para pejabat pemerintahan serta kerabat keraton Kacirebonan. Maka hal ini adalah bagian dari upaya Sanggar Pringgadhing untuk dapat mempertahankan eksistensi tari Ronggeng Bugis sekaligus menjaga dan melestarikan tari Ronggeng Bugis milik Sanggar Pringgadhing khususnya dan tari Ronggeng Bugis Cirebon pada umumnya. 


\section{BAB V}

PENUTUP

\subsection{Simpulan}

Tari Ronggeng Bugis masih diakui eksistensinya oleh masyarakat Cirebon. jadi tari Ronggeng Bugis masih eksis atau keberadaannya diakui oleh masyarakat Cirebon karena masih sering pentas diberbagai acara sampai sat ini selain itu karena tariannya yang lucu. Kelucuan itu berasal dari aspek-aspek yang ada dalam bentuk pertunjukan yaitu dengan para pelaku atau penari laki-laki yang menarikannya dengan gerakan perempuan sehingga menimbulkan ketertarikan para penonton atau penikmat seni, kemudian dengan dukungan tata rias dan busana yang membuat karakter lucu semakin muncul, musik iringan yang sederhana namun membuat tari Ronggeng Bugis semakin menarik, tempat pertunjukan yang tidak hanya dapat dipentaskan di atas panggung namun bisa juga dijalan raya, lapangan atau Helaran, dan terakhir faktor pendukung yang penting untuk menetukan eksistensi tari Ronggeng Bugis yaitu penonton atau masyarakat yang menikmati pertunjukan tari Ronggeng Bugis yang merupakan bagian dari apresiator seni.

Bertahannya tari Ronggeng Bugis sampai tahun 2017 ini tentu dipengaruhi oleh minat masyarakat atau penonton pada tari Ronggeng Bugis. Sanggar Pringgadhing juga ikut melestarikan dengan adanya perkembangan dalam tari Ronggeng Bugis baik itu dalam hal garak maupun kostum dan musik iringannya, kemudian Sanggar Pringgadhing juga masih mempertahankan keaslian dari tari Ronggeng Bugis dan menyebarluaskan tari Ronggeng Bugis melalui pendidikan dan budaya daerah setempat. Itulah yang membuat tari Ronggeng Bugis di 
Sanggar Pringgadhing sampai saat ini masih eksis dan selalu membuat penonton tertarik dan mengapresiasi tari Ronggeng Bugis.

\subsection{Saran}

Untuk Sanggar Pringgadhing agar bisa mencari penerus yang siap untuk menarikan tari Ronggeng Bugis, agar tari Ronggeng Bugis mempunyai regenerasi. Tidak hanya orang-orang itu saja yang menarikan tari Ronggeng Bugis, cobalah untuk mencari para penari yang lebih muda dan mempercayai mereka agar bisa menarikan tari Ronggeng Bugis dengan baik, sehingga lebih banyak lagi yang tertarik untuk belajar atau mempelajari tari Ronggeng Bugis, dan tari Ronggeng Bugis semakin diakui lagi eksistensinya oleh masyarakat Cirebon.

Kemudian dibidang administrasi saran yang diberikan adalah lebih menjaga lagi dokumen maupun dokumentasi mengenai tari Ronggeng Bugis. Tidak hanya untuk tari Ronggeng Bugis saja namun untuk semua kesenian yang ada di Sanggar Pringgadhing agar dapat didokumentasikan dengan baik dan disimpan dengan baik. Supaya jika ada peneliti-peneliti berikutnya menjadi lebih mudah dalam mendapatkan data yang lebih lengkap dan relevan.

Bagi Dinas Budaya Pariwisata Pemuda dan Olahraga Kabupaten Kota Cirebon untuk lebih memberikan apresiasinya terhadap seni tari Ronggeng Bugis baik dalam hal pementasan, maupun publikas lewat buku atau internet agar bisa lebih mudah lagi diakses oleh masyarakat khususnya tentang sejarah keseniankesenian yang ada di Cirebon dan salah satunya adalah tari Ronggeng Bugis supaya kesenian tersebut tetap terjaga eksistensinya karena tari Ronggeng Bugis 
juga merupakan salah satu asset bangsa yang harus dikembangkan dan dilestarikan eksistensinya.

Saran bagi para seniman dan dinas kebudayaan setempat untuk meningkatkan sosialisasi tentang seni budaya daerah Cirebon khususnya tari Ronggeng Bugis agar bisa lebih dikenal lagi tidak hanya di daerah Kabupaten Kota Cirebon, dan Jawa Barat bahkan diluar itu karena tari juga meruapakan salah satu media komunikasi, begitupun dengan tari Ronggeng Bugis. Maka melalui tarian representasi kehidupan dapat disampaikan melalui makna yang terkandung dalam gerak tari. Namun sangat disayangkan jika generasi muda kurang memiliki ketertarikan terhadap tari.

Saran bagi pengembangan ilmu hendaknya ada peneliti lain yang tertarik untuk meneliti tari Ronggeng Bugis dalam aspek kajian yang lebih mendalam dan berbeda untuk menjaga eksistensi tari Ronggeng Bugis sekaligus melestarikannya. 


\section{DAFTAR PUSTAKA}

Sumandiyo, Hadi Y. 2006. Seni Dalam Ritual Agama. Yogyakarta: penerbit buku PUSTAKA.

Djelantik.A.A.M. 1999. Estetika Sebuah Pengantar. Masyarakat Seni Pertunjukan Indonesia. Bandung.

Ambarwangi, S., \& Suharto, S. (2014). REOG AS MEANS OF STUDENTS' APPRECIATION AND CREATION IN ARTS AND CULTURE BASED ON THE LOCAL WISDOM. Harmonia: Journal Of Arts Research And Education, 14(1), 37-45. doi:http://dx.doi.org/10.15294/harmonia.v14i1.2789

Bisri, M. (2011). Perkembangan Tari Ritual Menuju Tari Pseudoritual di Surakarta (The Development of Ritual Dance toward Pseudoritual Dance in Surakarta). Harmonia: Journal Of Arts Research And Education, 8(1). doi:http://dx.doi.org/10.15294/harmonia.v8i1.798

Suharto, S., \& Aesijah, S. (2014). THE LESUNG MUSIC IN THE VILLAGE OF LEDOK BLORA REGENCY. Harmonia: Journal Of Arts Research And $\quad$ Education, 65-71. doi:http://dx.doi.org/10.15294/harmonia.v14i1.2851

Handayaningrum, W. (2016). Science-Based Thematic Cultural Art Learning in Primary School (2013 Curriculum). Harmonia: Journal Of Arts Research And Education, 16(1), 14-23. doi:http://dx.doi.org/10.15294/harmonia.v16i1.6766

Idris, M., Mustaffa, N., \& Yusoff, S. (2016). Preservation of Intangible Cultural Heritage Using Advance Digital Technology: Issues and Challenges. Harmonia: Journal Of Arts Research And Education, 16(1), 1-13. doi:http://dx.doi.org/10.15294/harmonia.v16i1.6353

Suharto, S. (2000). ACTION RESEARCH TO SOLVE MUSIC TEACHING PROBLEMS IN THE SCHOOL. Harmonia: Journal Of Arts Research And Education, $1(1)$. doi:http://dx.doi.org/10.15294/harmonia.v1i1.835

Suharto, S. (2011). Refleksi Teori Kritik Seni Holistik : sebuah Pendekatan Alternatif dalam Penelitian Kualitatif bagi Mahasiswa Seni (Reflection on Art Criticism and Holistic Art Criticism : an Alternative Approach of Qualitative Research for Art Students). 
Harmonia: Journal Of Arts Research And Education, 8(1). doi:http://dx.doi.org/10.15294/harmonia.v8i1.803

Soemaryatmi, -. (2011). Tari Slawatan Angguk Rame Ngargatantra : Kajian Sosiologis (Slawatan Angguk Rame Ngargatantra Dance : The Sociology Study). Harmonia: Journal Of Arts Research And Education, 8(1). doi:http://dx.doi.org/10.15294/harmonia.v8i1.802

Handayani, C. (2011). Bangkitnya Kembali Kesenian Tradisional Rakyat sebagai Warisan Budaya Nenek Moyang di Bukit Menoreh Bhumi Sabhara Budhara (The Re-animation of the Traditional Folk Arts as the Ancestors Cultural Heritage at Bukit Menoreh Bhumi Sambhara Budhara). Harmonia: Journal Of Arts Research And Education, 7(2). doi:http://dx.doi.org/10.15294/harmonia.v7i2.754

Kusumadewi, L., \& Suharto, S. (2011). PENINGKATAN HASIL BELAJAR SENI MUSIK DENGAN MEDIA AUDIO VISUAL MELALUI METODE BERVARIASI. Harmonia: Journal Of Arts Research And Education, 10(2). doi:http://dx.doi.org/10.15294/harmonia.v10i2.63

Widodo, -. (2011). LELAGON DOLANAN ANAK DAN PENDIDIKAN KARAKTER. Harmonia: Journal Of Arts Research And Education, 10(2). doi:http://dx.doi.org/10.15294/harmonia.v10i2.62

Indriyanto, -. (2011). KEBANGKITAN TARI RAKYAT DI DAERAH BANYUMAS (The Resurgence of Folk Dances in Banyumas). Harmonia: Journal Of Arts Research And Education, 2(2). doi:http://dx.doi.org/10.15294/harmonia.v2i2.853

Linggasari, Dewi. 2007. Ronggeng. Yogyakarta: Bigraf

Narawati, Tati. 2003. Wajah Tari Sunda dari masa ke masa. Bandung: P4ST.UPI.

Jazuli, M. 2016. Peta Dunia Seni Tari. Sukoharjo: CV. Farishma Indonesia. . 2008a. Paradigma Kontekstual Pendidikan Seni. Surabaya: Unesa Press. 1994. "Telaah Teoritis Tari”. Semarang: IKIP Semarang Press.

Widyastutiningrum dan Wahyudiarto. 2014. "Pengantar Koreografi". Surakarta: ISI Press Surakarta.

Sugiyono, 2010. Metode Penelitian Pendidikan (pendekatan kuantitatif, kualitatif, dan $R \& D)$. Bandung: Alfabeta. 
Moleong, Lexy J., 2010. Metodelogi penelitian kualitatif. Bandung: Rosdakarya.

Ikbar, Yanuar. 2012. “Metode Penelitian Sosial Kualitatif”. Bandung: PT RefikaAditama.

Maryono. 2015. Penelitian Kualitatif Seni Pertunjukan. Surakarta: ISI Press Solo.

Setiawati, Rahmida dkk. 2008. Seni Tari Untuk Sekolah Menengah Kejuruan. Jakarta: Direktorat Jenderal Manajemen Pendidikan Dasar dan Menengah.

Salim. 2015. “Perkembangan Dan Eksistensi Musik Tarling Di Cirebon”. Journal of art education 4 (1).

Wulan, M. 2013. "Pembelajaran Tari Ronggeng Bugis Di SMK N 1 Kedawung Kabupaten Cirebon”. Skripsi: Universitas Pendidikan Indonesia.

Wisudawaty, Hanna. 2009. "Komunikasi Ekspresif Tari Ronggeng Bugis Cirebon”. Skripsi: Universitas Islam Bandung.

Pradewi dan Lestari. Harmonia 1(1) 2012. "Eksistensi Tari Opak Abang Sebagai Tari Daerah Kabupaten Kendal”. (diunduh pada tanggal 27 Juli 2016).

Prihatini. Mudra 27 (1) 2012. “Eksistensi Seni Pertunjukan Rakyat di Daerah Kedu Jawa Tengah”. (diunduh pada tanggal 27 Juli 2016).

Wahidin, Dede. "Ronggeng Bughis". Sumber: disporbudpar.cirebonkota.go.id (diunduh tanggal 29 desember 2015).

Wisata Cirebon. "Ronggeng Bugis, Tarian Jenaka Warisan Budaya Cirebon". Sumber: wisatadanbudaya.blogspot.co.id (diunduh tanggal 29 desember 2015).

Admin. "Ronggeng Bughis". Sumber: disparbud.jabarprov.go.id. (diunduh tanggal 29 desember 2015).

Admin, "Galeri Haul Handoyo Tokoh Seniman Cirebon". Sumber: disbudparpora.cirebonkab.go.id (diunduh tanggal 29 Mei 2017). 


\section{Lampiran 1}

\section{GLOSARIUM}

Basa Cerbon : bahasa Cirebon yang dituturkan di daerah pesisir utara

Jawa Barat

Blubuk Nyungkur : : loncat-loncat sambil maju

Bubungahan : bersenang-senang

Dedengulan : menganggukan kepala secara berpasangan

Helaran : pawai

Injen : mengintip

Kasultanan $\quad$ : tempat tinggal seorang sultan atau pemimpin kerajaan

Lenggang : berjalan

Longok : melihat

Napak Gili : berjalan pelan-pelan 


\section{Lampiran 2}

\section{Pedoman Observasi}
A. Tujuan

Peneliti melakukan observasi untuk mengetahui bagaimana Eksistensi Tari

Ronggeng Bugis di Sanggar Pringgadhing Plumbon Cirebon.

B. Pembatasan Observasi

1. Bentuk Pertunjukan Tari Ronggeng Bugis

2. Eksistensi Tari Ronggeg Bugis

C. Aspek Observasi

1. Tempat penelitian

2. Tempat pertunjukan Tari Ronggeng Bugis

3. Pementasan Tari Ronggeng Bugis

D. Observasi yang terkait dengan data pendukung

1. Letak geografis Sanggar Pringgadhing Plumbon Cirebon .

2. Jumlah penduduk dan tingkat pendidkan masyarakat Desa Plumbon Kabupaten Cirebon .

3. Keadaan ekonomi masyarakat Desa Plumbon Kabupaten Cirebon

4. Kesenian di daerah Plumbon Kabupaten Cirebon 


\section{Lampiran 3}

\section{Pedoman Wawancara}
A. Tujuan

Wawancara dalam penelitian ini bertujuan untuk mendapatkan data baik melalui bentuk tulisan atau rekaman tentang Eksistensi Tari Ronggeng Bugis di Sanggar Pringgadhing Plumbon Cirebon.

B. Pembatasan Masalah

1. Bentuk Pertunjukan Tari Roenggeng Bugis

2. Eksistensi Tari Ronggeng Bugis

C. Responden atau Narasumber

1. Ketua Sanggar Pringgadhing

2. Kepala Desa Plumbon

3. Kepala Dinas Kebudayaan Pariwisata Olahraga dan Pemuda Kabupaten Cirebon

4. Pelatih Tari Ronggeng Bugis

5. Penari Tari Ronggeng Bugis

6. Masyarakat sekitar dan Penonton

D. Pedoman Wawancara (Kisi-kisi wawancara)

\begin{tabular}{|l|l|l|l|}
\hline No & \multicolumn{1}{|c|}{ Aspek } & \multicolumn{1}{|c|}{ Butir wawancara } & \multicolumn{1}{|c|}{ Informan } \\
& Wawancara & & \\
\hline 1. & Eksistensi & Keberadaan dan & Ketua Sanggar, dan \\
& & sejarah & Dinas Kebudayaan \\
\hline & & Pementasaan & Ketua Sanggar, \\
\hline
\end{tabular}




\begin{tabular}{|c|c|c|c|}
\hline & & & pelatih, dan penari \\
\hline & & $\begin{array}{l}\text { Pembelajar Tari } \\
\text { Ronggeng Bugis di } \\
\text { Sanggar } \\
\text { Pringgadhing }\end{array}$ & $\begin{array}{l}\text { Ketua sanggar, pelatih, } \\
\text { penari, dan } \\
\text { masyarakat atau } \\
\text { sekolah }\end{array}$ \\
\hline \multirow[t]{7}{*}{2.} & $\begin{array}{l}\text { Bentuk } \\
\text { Pertunjukan }\end{array}$ & Pelaku & $\begin{array}{l}\text { Ketua Sanggar, } \\
\text { pelatih, dan penari }\end{array}$ \\
\hline & & Gerak & pelatih, dan penari \\
\hline & & $\begin{array}{l}\text { Tata Busana atau } \\
\text { kostum }\end{array}$ & $\begin{array}{l}\text { Ketua Sanggar, } \\
\text { pelatih, dan penari }\end{array}$ \\
\hline & & Tata Rias & $\begin{array}{l}\text { Ketua Sanggar, } \\
\text { pelatih, dan penari }\end{array}$ \\
\hline & & Musik iringan & $\begin{array}{l}\text { Ketua Sanggar, } \\
\text { pelatih, dan penari, } \\
\text { dan pemusik }\end{array}$ \\
\hline & & Tempat Pertunjukan & $\begin{array}{l}\text { Ketua sanggar, dinas } \\
\text { kebudayaan, pelatih, } \\
\text { dan penari }\end{array}$ \\
\hline & & Apresiator & $\begin{array}{l}\text { Ketua sanggar, dinas } \\
\text { kebudayaan, penari } \\
\text { dan penonton atau } \\
\text { masyarakat sekitar. }\end{array}$ \\
\hline
\end{tabular}




\section{Lampiran 4}

\section{Daftar Pertanyaan}

A. Tempat Penelitian

1. Kapan Sanggar Pringgadhing didirikan?

2. Siapa pendiri Sanggar Pringgadhing?

3. Siapa Pemimpin atau ketua Sanggar Pringgadhing?

4. Apa saja fasilitas yang tersedia untuk menunjang kegiatan pembelajaran tari di Sanggar Pringgadhing?

5. Siapa saja peserta didik dan pelatih di Sanggar Pringadhing?

6. Apa saja materi tari yang diajarkan di Sanggar Pringgadhing ?

B. Objek Kajian Penelitian

1) Wawancara dengan Bapak Windu selaku pemimpin Sanggar Pringgadhing

1. Bagaimana asal-usul atau sejarah terciptanya Tari Ronggeng Bugis?

2. Siapa pencipta Tari Ronggeng Bugis?

3. Apa cerita atau makna yang terkandung dalam Tari Ronggeng Bugis?

4. Apa yang melatarbelakangi bapak Handoyo (alm) mengembangkan Tari Ronggeng Bugis?

5. Merupakan tari jenis apa? Kreasi atau tradisi? Mengapa demikian?

6. Tari Rongeng Bugis yang ada di Sanggar Pringgadhing sering ditampilkan dalam acara apa saja? 
7. Dalam satu bulan berapa kali ditampilkan?

8. Adakah tarif untuk penonton jika Sanggar Pringgadhing mengadakan pementasan Tari Ronggeng Bugis?

9. Adakah perbedaan Tari Ronggeng Bugis Di Sanggar Pringgadhing dengan sanggar lain?

10. Bagaimana musik/iringan Tari Ronggeng Bugis di Sanggar Pringgadhing?

11. Apa saja nama-nama gerak dalam Tari Ronggeng Bugis di Sanggar Pringgadhing?

12. Adakah properti yang digunakan dalam Tari Ronggeng Bugis di Sanggar Pringgadhing?

13. Bagaimana upaya Sanggar Pringgadhing dalam mempertahankan Tari Ronggeng Bugis?

14. Apakah sudah ada kerjasama dengan instansi tertentu dalam upaya mempertahankan Tari Ronggeng Bugis?

15. Adakah faktor penghambat dalam upaya mempertahankan eksitensi Tari Ronggeng Bugis? Apa saja?

16. Apa solusi yang digunakan dalam mengatasi faktor penghambat tersebut agar Tari Ronggeng Bugis tetap diminati masyarakat?

2) $\mathrm{Bu}$ Ati selaku pengajar di Sanggar Pringgadhing Cirebon

1. Siapa saja yang biasa menarikan Tari Ronggeng Bugis?

2. Tari Ronggeng Bugis Dapat ditarikan oleh berapa orang?

3. Bagaimana eksitensi Tari Ronggeng Bugis di kalangan pelajar? 
4. Apakah ada perbedaan saat ibu mengajarkan Tari Ronggeng Bugis pada pelajar, mahsiswa atau orang dewasa yang sudah tidak sekolah?

5. Apakah ada kesulitan dalam memberikan materi Tari Ronggeng Bugis?

6. Bagaimana rias dan busana Tari Ronggeng Bugis ?

3) Dinas Kebudayaan Pariwisata Pemuda dan Olahraga (DISBUDPARPORA) Kabupaten Cirebon

1. Apakah bapak tahu tentang Tari Ronggeng Bugis di Sanggar Pringgadhing

2. Apakah DISBUDPARPORA pernah mengusahakan untuk mengadakan pementasan Tari Ronggeng Bugis, kapan dan dimana?

3. Apakah ada upaya dari DISBUDPARPORA untuk memperkenalkan Tari Ronggeng Bugis kepada masyarakat luas? Bagaimana caranya?

4. Apakah ada faktor penghambat dalam memperkenalkan Tari Ronggeng Bugis?

5. Apakah sudah ada kerjasama dari dinas pariwisata dengan pihak lain?

4) Kepala Sekolah SMK N 1 Kedawung

1. Bagaimana asal mulanya Tari Ronggeng Bugis bisa dijadikan materi ujian praktik tari di sekolah? 
2. Mengapa memilih Tari Ronggeng Bugis untuk dijadikan materi ujian praktik?

3. Bagaimana respon para siswa saat tahu Tari Ronggeng Bugis yang harus mereka pelajari untuk ujian praktik?

4. Bagaimana eksistensi Tari Ronggeng Bugis di Sanggar Pringgadhing menurut bapak/ibu?

5. Berapa lama Tari Ronggeng Bugis dijadikan materi ujian praktik tari di sekolah?

5) Penari Tari Ronggeng Bugis

1. Mengapa anda mempelajari Tari Ronggeng Bugis?

2. Apakah keunikan dari Tari Ronggeng Bugis?

3. Apakah Tari Ronggeng Bugis sulit untuk dipelajari?

4. Bagaimana cara anda untuk ikut serta Mengenalkan Tari Ronggeng Bugis pada masyarakat luas?

5. Apakah menurut anda Tari Ronggeng Bugis eksis dan diminati masyarakat?

6) Apresiator

1. Apakah anda mengetahui Tari Ronggeng Bugis?

2. Tarian seperti apa Tari Ronggeng Bugis menurut pandangan anda?

3. Sejak kapan anda mengetahui adanya Tari Ronggeng Bugis?

4. Apakah Tari Ronggeng Bugis yang ada di Sanggar Pringgadhing sering tampil dalam acara-acara di Cirebon?

5. Apakah Tari Ronggeng Bugis diakui keberadaannya? 
6. Setelah anda menonton Tari Ronggeng Bugis, apa pendapat anda tentang tarian ini dan apa harapan anda untuk Tari Ronggeng Bugis? 


\section{Lampiran 5}

\section{DOKUMENTASI}

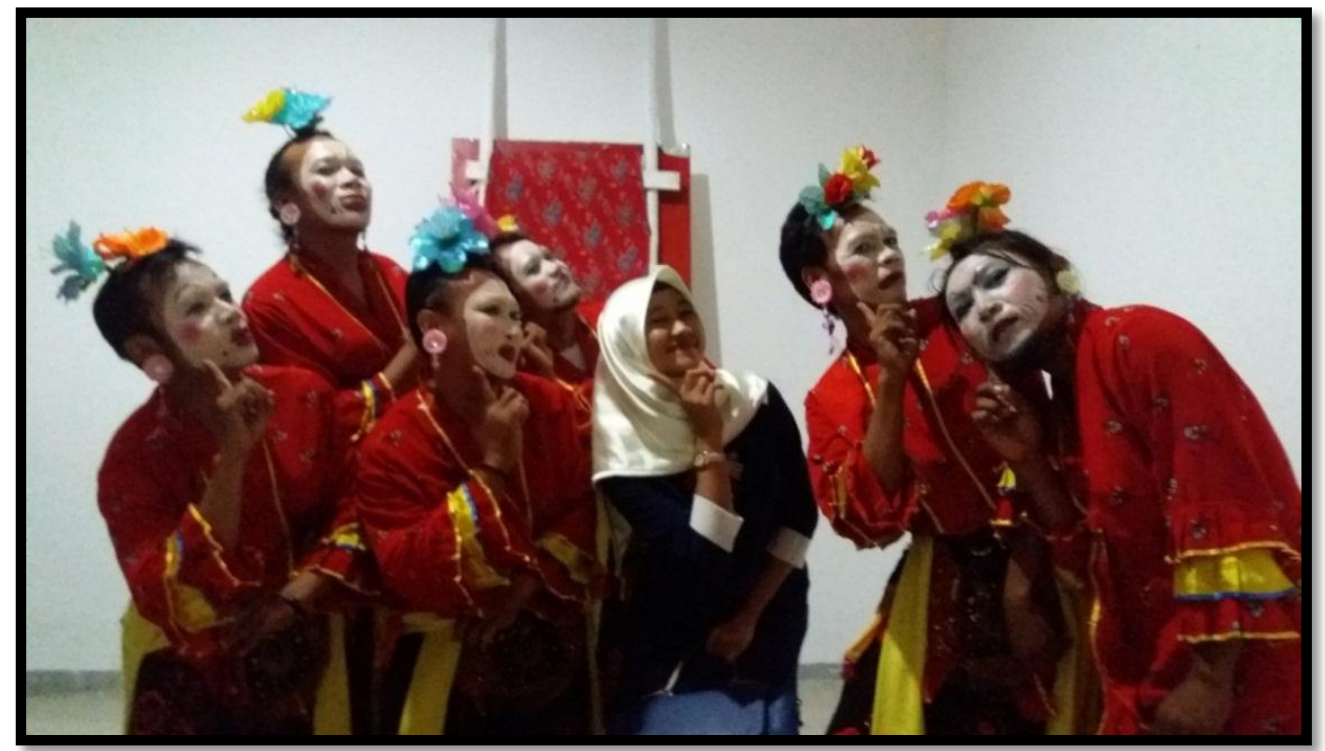

Foto bersama para penari Ronggeng Bugis dalam acara Jaka Rara Kota Cirebon (sumber: adi, 2017)

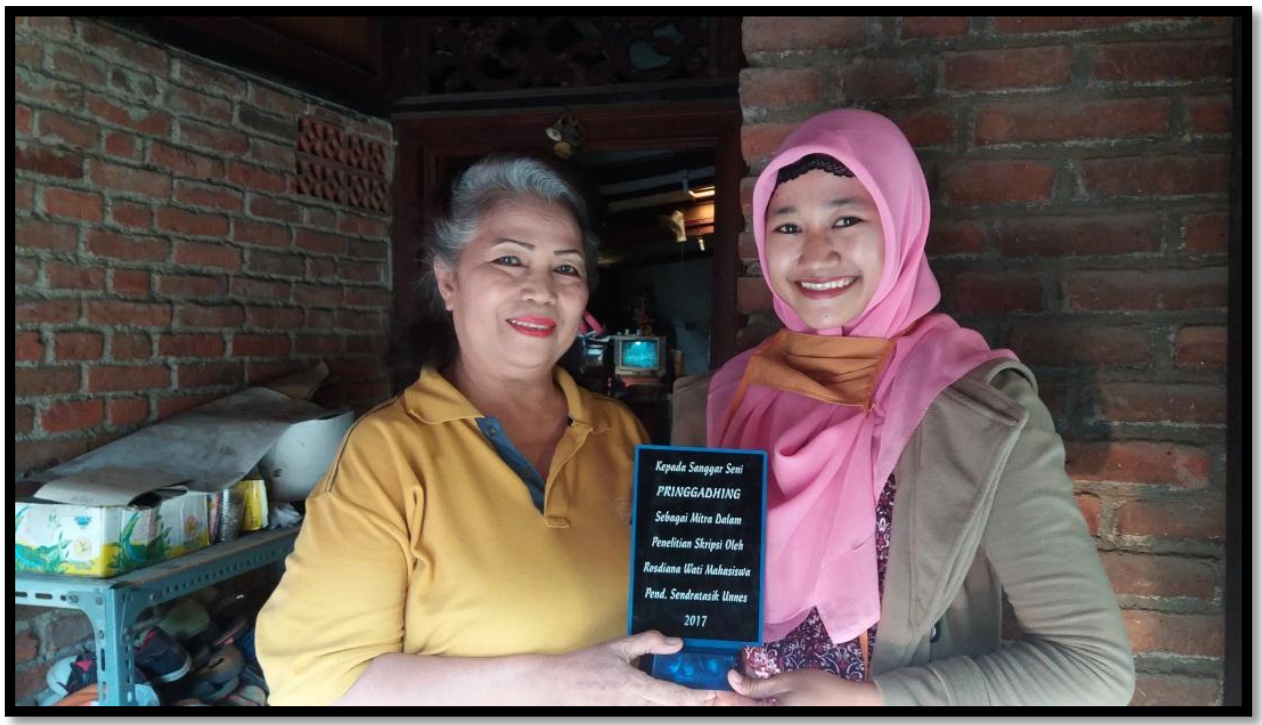

Foto bersama ibu Ati pelatih tari di Sanggar Pringgadhing saat pemberian kenangkenangan

(sumber: adi, 2017) 


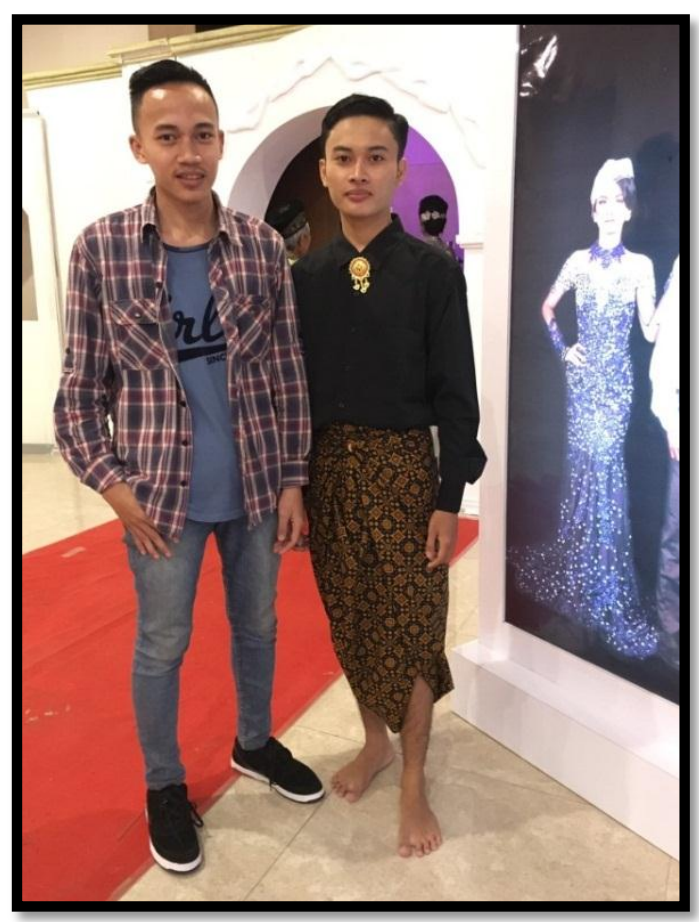

Foto kedua narasumber sebagai penonton (sumber: rosdiana, 2017)

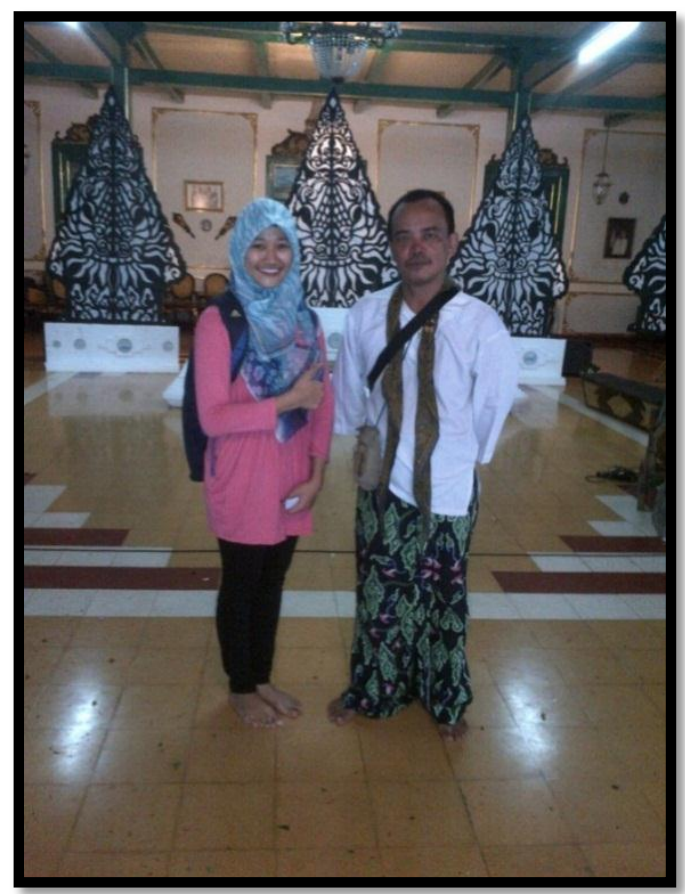

Foto bersama pak Heri sebagai penari tari Ronggeng Bugis (sumber: oman, 2017) 


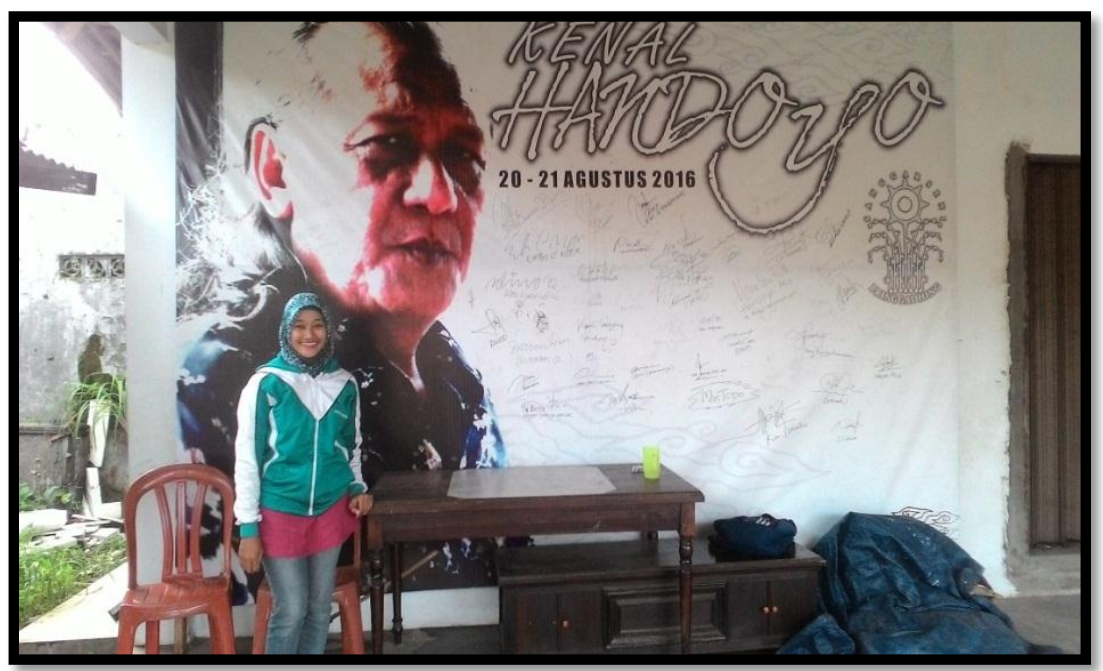

Foto observasi awal di Sanggar Pringgadhing (sumber: Puji, 2017)

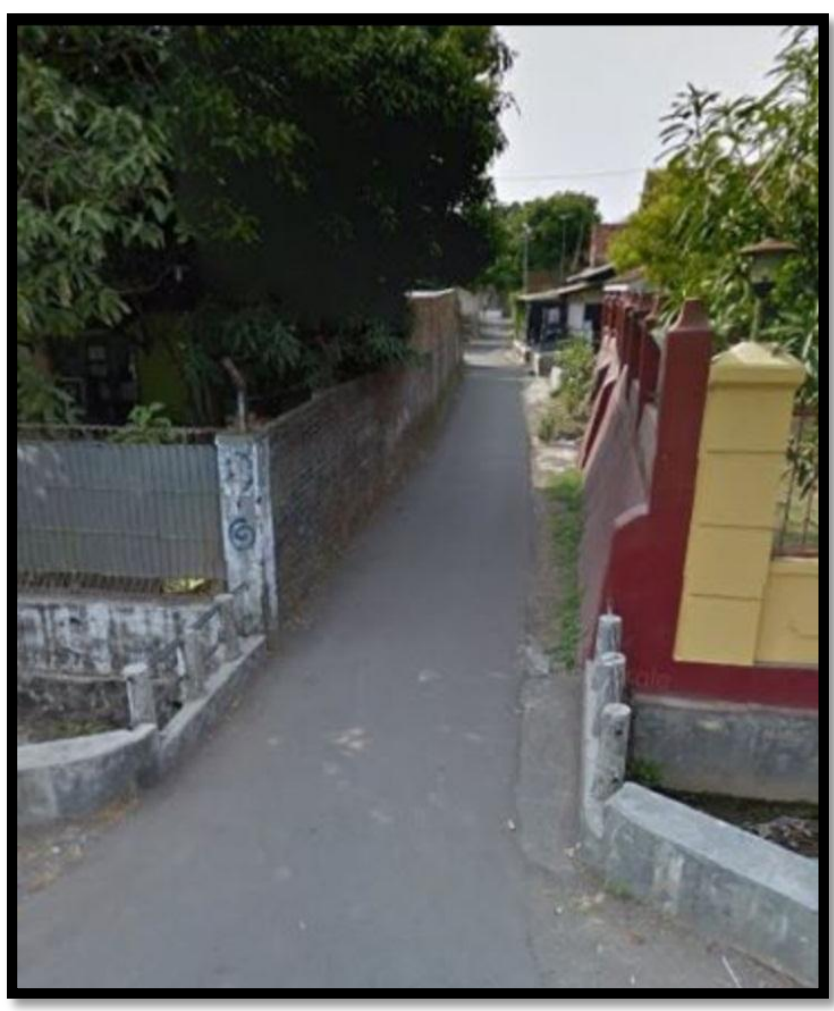

Foto jalan menuju Sanggar Pringgadhing (sumber: Opan, 2017) 


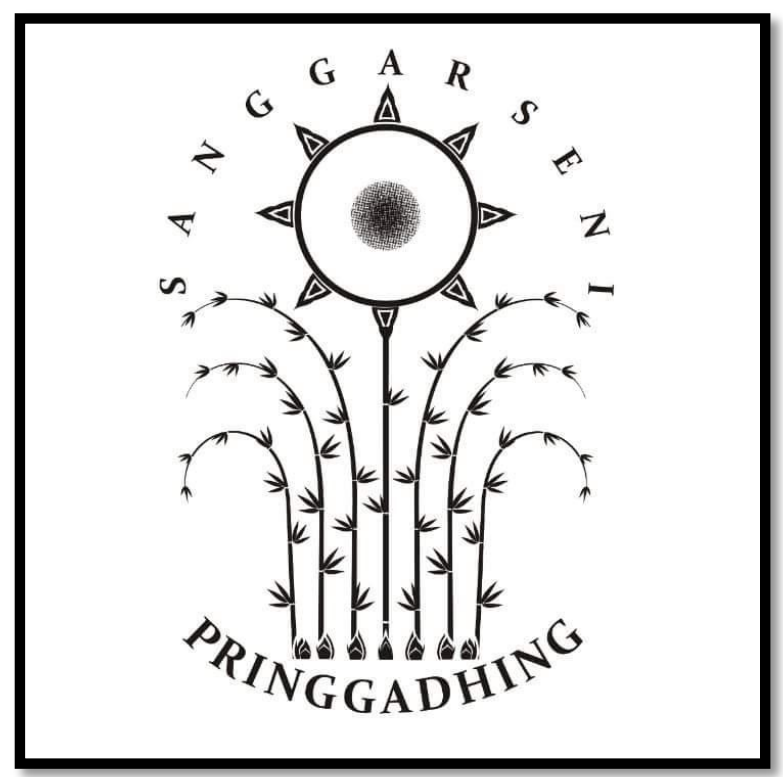

Gambar Logo Sanggar Pringgadhing

(sumber: windu, 2017)

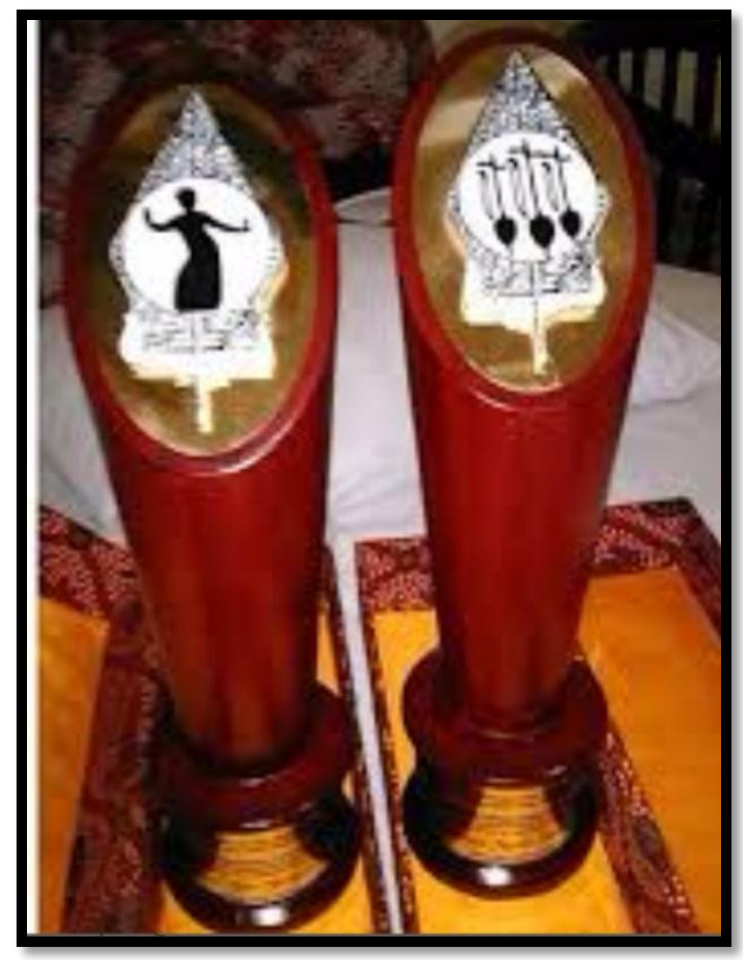

Foto piala penghargaan Sanggar Pringgadhing mewakili Cirebon sebagai penyaji terbaik 1 untuk karawitan dan penyaji terbaik 3 untuk seni tari dalam acara

Pasanggiri Teater, Karawitan, dan Tari.

(sumber: Disbudparpora, 2017) 


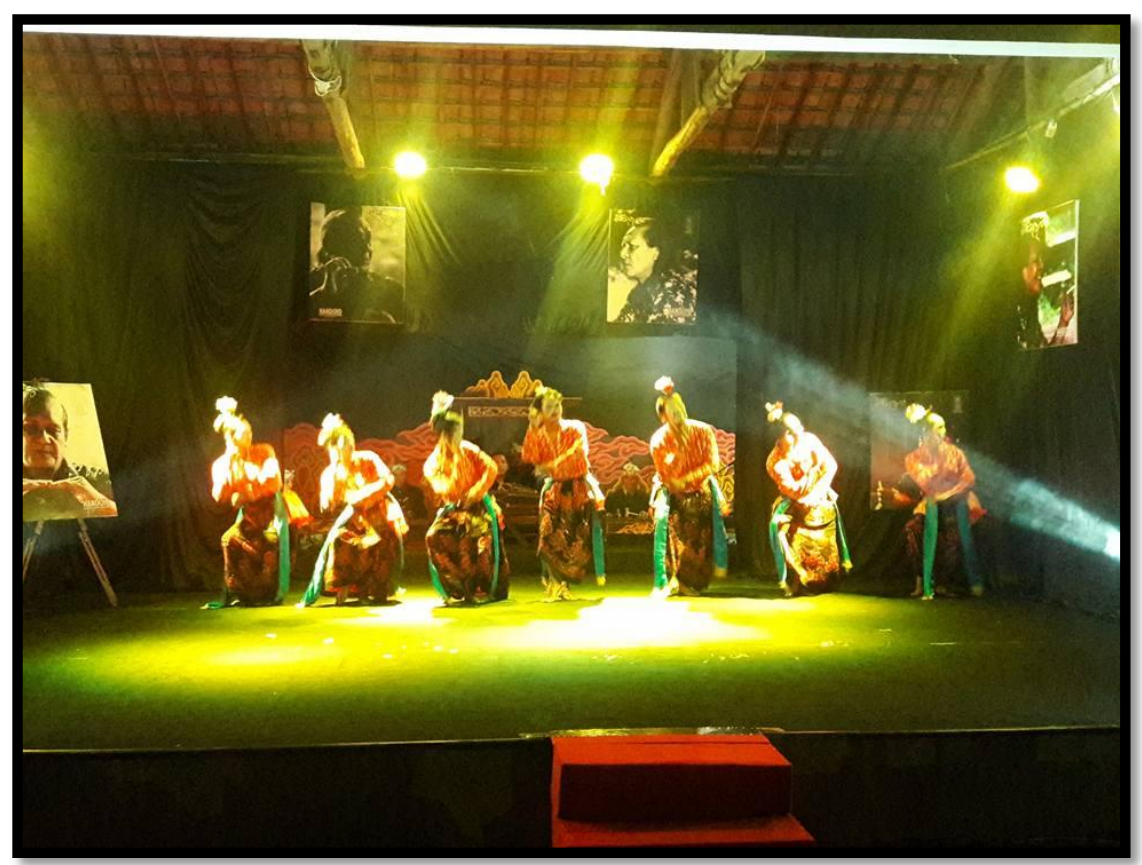

Foto penampilan tari Ronggeng Bugis dalam acara Haul alm. Bapak Handoyo (sumber: Disbudparpora, 2017)

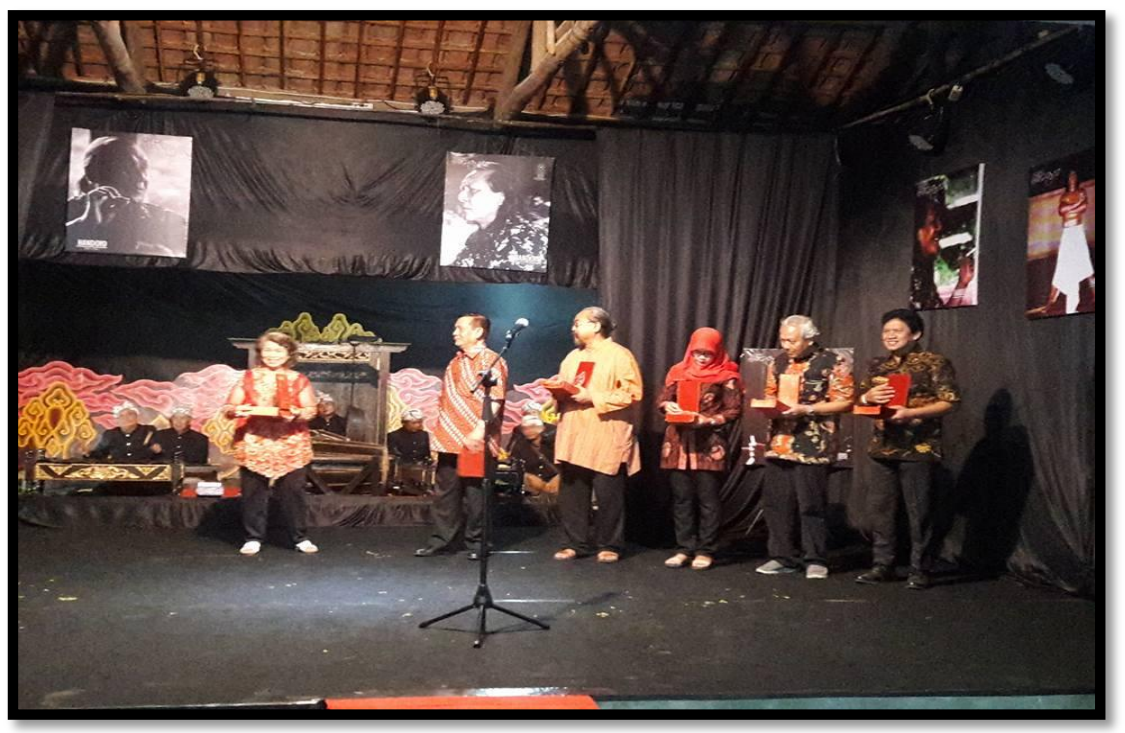

Foto pemberian penghargaan dari pemerintahan Disbudparpora untuk alm. bapak Handoyo yang diwakili oleh istri dalam acara Haul alm.. bapak Handoyo (sumber: Disbudparpora, 2017) 


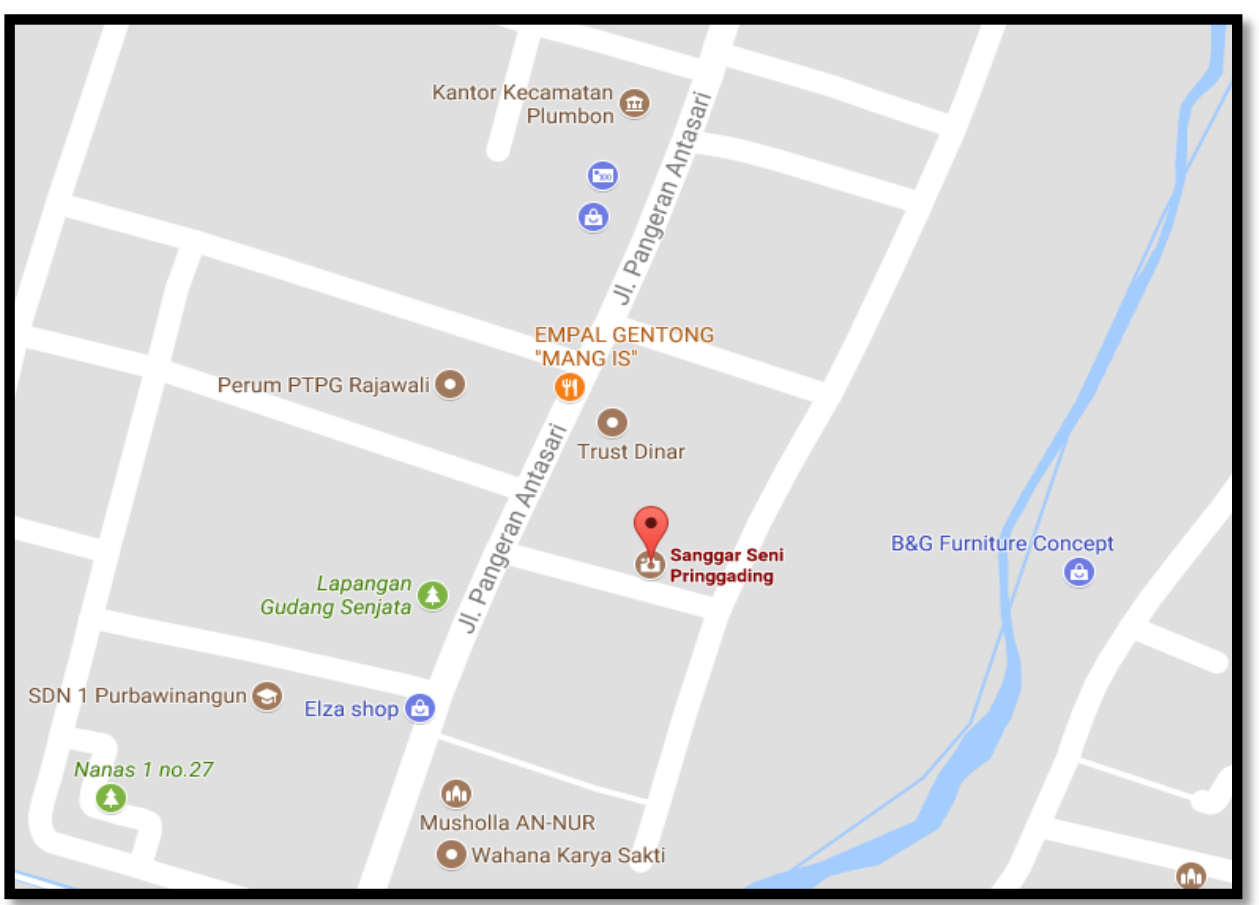

Gambar peta Sanggar Seni Pringgadhing (Sumber: Google Maps, 2017)

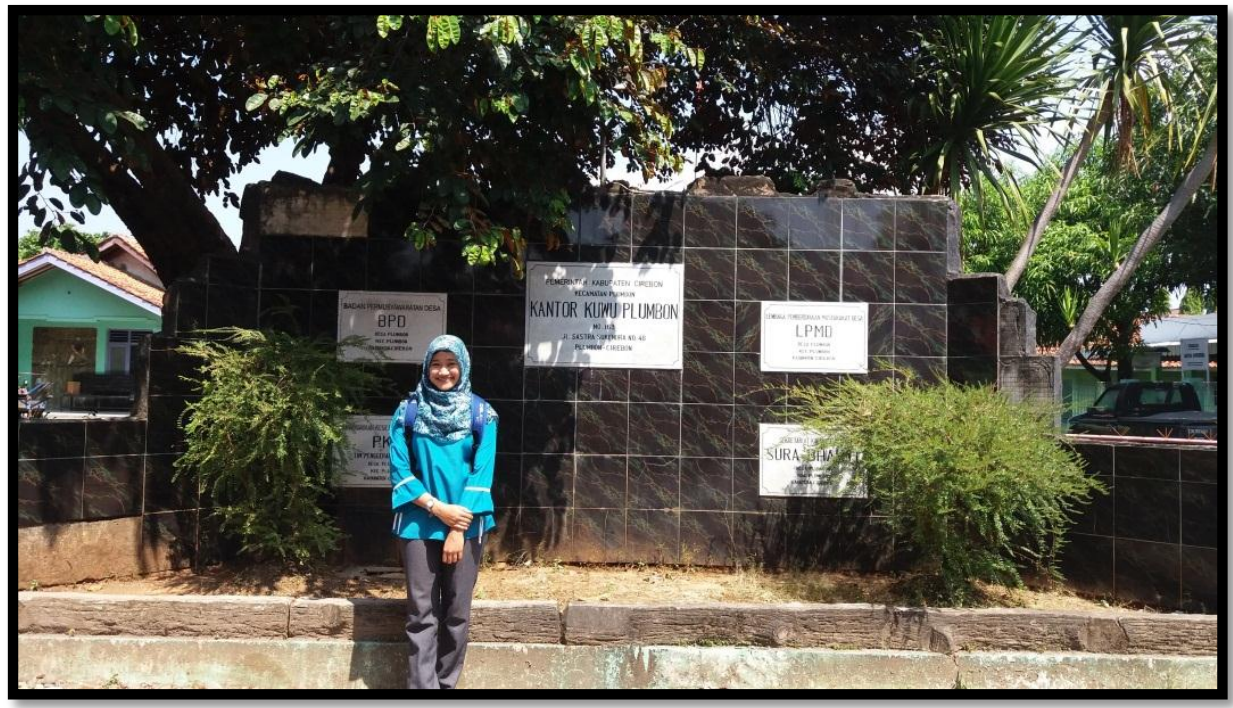

Foto didepan Kantor Kuwu Plumbon (Sumber: Adi, 2017) 